\title{
DE AFWIJKINGEN VAN HET MOHAMMEDAANSCHE VERMOGENSRECHT OP JAVA EN MADOERA
}

DOOR

\author{
¿Mr. L. W. C. VAN DEN BERG.
}

In mijne uiteenzetting van de afwijkingen van het Moḥammedaansche familie- en erfrecht op Java en Madoera, opgenomen in dl. VII, 5 $5^{\text {de }}$ Volgreeks, van de Bijdragen tot de Taal-, Landen Volkenkunde van Nederlandsch-Indië, heb ik uiteengezet, welke, naar mijne meening, uit een juridisch oogpunt de verhouding is tussehen de Mohammedaansche wet en het inlandsche gewoonterecht op bedoelde eilanden, en heb ik getracht de voornaamste punten van verschil tusschen beide rechtsbronnen, wat het familie- en erfrecht betreft, te formuleeren. De waardeering, welke deze poging heeft ondervonden, geeft mij aanleiding thans hetzelfde te beproeven ten opzichte van het vermogensrecht. Ik zal daarbij de in genoemd opstel aangenomen methode volgen, ten einde beide stukken zooveel mogelijk bij elkander te doen aansluiten. Voor die methode wordt dan ook thans kortheidshalve verwezen naar eerstbedoeld stuk, en naar hetgeen ik in mijne Nalezing in dl. I der $6^{\text {de }}$ Volgreeks van dit Tijdschrift op p. 308 en vv. aanvoerde ${ }^{1}$.

1 Bij het ter perse gaan van het hier volgende opstel ontving ik het eerste nummer van Wet en Adat (Batavia 1896), een op onbepaalde tijden te verschijnen tijdschrift, uitgegeven onder leiding van den heer Mr. J. A. Nederburgh. In dit nummer wordt o. a. door dien geachten schrijver opgekomen tegen mijne evenbedoelde constructie van de verhouding tusschen de Mohammedaansche wet en het inlandsche gewoonterecht. Ik geloof, dat het verschil, tusschen de constructie van den heer Nederburgh en de mijne, inderdaad minder groot is, dan hij vermeent, en dat, waar hij als slotsom van zijne redeneering, op p. 72 , zegt hoe dan, volgens hem, het dogmatische Mohammedaansche recht moet worden toegepast, eene uitspraak wordt gegeven, welke, althans voor de practijk, van mijn gevoelen niet noemenswaardig afwijkt. Immers wensch ook ik niet anders dan dat, door de adat van den Islam overgenomen, instellingen naar de Mohamme- 


\section{$\S$ 1. Algemeene Beschouwingen.}

Vogens de artt. 11-13 der Algemeene Bepalingen van Wetgeving voor Nederlandsch-Indië, in verband met art. 75 van het Regeeringsreglement worden op de Inlandsche of daarmede gelijkgestelde bevolking alleen dan hare godsdienstige wetten, volksinstellingen en gebruiken toegepast, wanneer geene vrijwillige onderwerping aan het Europeesche burgerlijk en handelsrecht heeft plaats gevonden; voorts wanneer die wetten, instellingen en gebruiken niet in strijd zijn met algemeen erkende beginselen van billijkheid en rechtvaardigheid, en eindelijk, wanneer onze wetgever de regeling van het onderwerp niet aan zich heeft getrokken, hetzij door toepasselijkverklaring van het Europeesche recht op bedoelde bevolking, hetzij door opzettelijk, met het oog op haar, uitgevaardigde verordeningen, hetzij eindelijk door regeling van het onderwerp in het algemeen voor alle ingezetenen ${ }^{1}$.

Deze punten verdienen, wat het vermogensrecht aangaat, eene meer uitvoerige toelichting dan bij het familie- en erfrecht te pas kwam. Wat het eerste punt betreft, de vrijwillige onderwerping, zoo neemt men terecht aan, dat die ten aanzien van het familieen erfrecht alleen kan plaats hebben in het geval, bedoeld bij art. 15 Overg., waar als voorwaarde voor de bestaanbaarheid van een wettig huwelijk, tusschen personen behoorende tot de Europeesche

daansche wet worden opgevat en toegepast, - wanneer niet blijkt, dat de adat daaraan iets heeft veranderd. Die veranderingen zijn dus uitzonderingen, welke moeten bewezen worden, en men zal omgekeerd niet behoeven te bewijzen, dat elk voorschrift van de Mohammedaansche wet ten aanzien van zekere instellingen is gerecipieerd, indien de receptie van die instelling in het algemeen vaststaat. Dit nu, en niet meer, is hetgeen men onder receptio in complexu verstàat. Had de heer Nederburgh, nevens de door hem uit mijne Nalezing gegeven aanhalingen, ook geciteerd wat op p. 302 en vv. daarvan voorkomt, zoo zoude hij hebben bemerkt, dat hij mij Mohammedaansche gevoelens toedicht, welke ik niet huldig, en vermeen ook niet te hebben uitgesproken. Verder kan ik te dezer plaatse niet ingaan op het opstel van den heer Nederburgh, hetwelk ik, in complexu, d. w. z. zonder daarom nog elke zinsnede te onderschrijven, beschouw als één der meest doorwrochte commentaren, tot dusverre op art. 75 Reg. Regl. geleverd, en hetwelk stellig de bijzondere aandacht van den wetgever zal trekken, wanneer eenmaal tot herziening van bedoeld artikel zal worden overgegaan. Dat ik ten slotte aan het, door den heer Nederburgh opgerichte, juridische orgaan een lang en voorspoedig leven toewensch, behoef ik wel niet met vele woorden toe te lichten.

1 Zie, in denzelfden geest, Nederburgh, t. a. p., p. 46 en vv. 
of daarmede gelijkgestelde en tot de inlandsche of daarmede gelijkgestelde bevolking, wordt gevorderd, dat de inlandsche partij zich vooraf aan het geheele burgerlijk en handelsrecht der Europeesche partij hebbe onderworpen. De speciale onderwerping, met het oog op eene bepaalde rechtshandeling, bedoeld bij de artt. 11-13 Alg. Bepp., kan, ofschoon de woorden dier artikelen op zich zelve voor verschil van opvatting ruimte laten, alleen op het vermogensrẻcht betrekking hebben. Dit althans is het meest verbreide gevoelen ${ }^{1}$.

Deze bevoegdheid nu tot onderwerping aan het Europeesche burgerlijk en handelsrecht is langzamerhand van grooten invloed geworden op de toepasselijkheid van het inlandsche vermogensrecht. Op de hoofdplaatsen namelijk, en vooral op de groote handelsplaatsen langs Java's Noordkust, wordt het mecr en meer gebruik, dat, bij transacties van zoodanig belang, dat notarieele tusschenkomst daarbij wordt ingeroepen, speciaal wanneer Europeanen of aan het Europeesche recht onderworpen Vreemde Oosterlingen bij de zaak betrokken zijn, de inlandsche partij zich te dien aanzien onderwerpt aan het recht der wederpartij. Noodzakelijk is echter zulks niet ${ }^{2}$, daar, gelijk ik elders reeds ten opzichte van de notarieele testamenten der inlanders opmerkte ${ }^{3}$, de akte wel blijkens art. 19 Alg. Bepp., wat haren vorm betreft, per se door het Europeesche recht wordt beheerscht, maar niet ten opzichte van den materieelen inhoud. Het gevolg van dit meer en meer toenemend gebruik is natuurlijk, dat het inlandsche vermogensrecht, juist ten aanzien van de belangrijkste transacties, dikwijls niet van toepassing is. Intusschen mag niet worden uit het oog verloren dat, zelfs wanneer onderwerping aan het Europeesche recht bij het sluiten der overeenkomst heeft plaats gehad, de interpretatie der bewoordingen van de overeenkomst toch naar het inland-

1 Vergl. Handelingen der N. I. Juristenvereeniging, Jaarg. 1887, dl. I, p. 20 en 21.

${ }^{2}$ Maar wel hoogst wenschelijk. Mocht immers eene overeenkomst tusschen partijen, die aan een verschillend recht zijn onderworpen, gesloten worden, zonder dat men vooruit heeft bepaald door welk recht die overeenkomst zal worden beheerscht, en de overeenkomst later onverhoopt niet worden nagekomen, zoo zal de nakoming moeten worden gevorderd bij den rechter van de partij, welke in gebreke is. Die rechter zal dan op de overeenkomst het recht van den gedaagde moeten toepassen, zoodat de vraag, naar welk recht ten slotte de overeenkomst zal worden beoordeeld, onzeker blijft, totdat blijke wie van beide partijen in de voldoening aan hare verplichtingen te kort schiet.

3 Vergl. Familie- en erfrecht, p. 510, 511. 
sche recht moet geschieden, bijaldien partijen blijkbaar een inlandsch kontrakt op het oog hadden ${ }^{1}$. Als veel voorkomende overeenkomsten van laatstgenoemden aard, tusschen personen gesloten, die niet en die wel aan het Europeesche privaatrecht zijn onderworpen, noem ik hier slechts den verkoop met recht van wederinkoop, in zijne verschillende functies, de landhuurcontracten in de Vorstenlanden, het contractus aestimatorius en de meeste werkkontrakten met inlandsche arbeiders, over alle welke transacties later in dit opstel zal worden gehandeld.

Eene andere oorzaak van niet-toepasselijkheid van het inlandsche vermogensrecht is op dezelfde plaatsen gelegen in het feit, dat aldaar van de belangrijkste vaste goederen der inlanders de titels zijn ingeschreven in de Europeesche registers van eigendom en andere zakelijke rechten, met inachtneming der voorschriften van Ind. Stbl. 1834 No $27^{2}$. Dit zelfde geldt ook van de zoogenaamde particuliere landerijen bewesten en beoosten de rivier Tji Manoek, en van de perceelen domeingrond door het Gouvernement in erfpacht of opstal aan inlanders afgestaan. Daar in het algemeen de conflicten tusschen het Europeesche en het inlandsche recht moeten worden beoordeeld en opgelost naar de beginselen, in het internationaal privaatrecht gehuldigd, zoo zal men ook den inlander, naar analogie van art. $17 \mathrm{Alg}$. Bepp., voor alle zoodanige gronden als stilzwijgend onderworpen moeten aanmerken aan het Indische Burgerlijk Wetboek ${ }^{3}$. Natuurlijk is hij tevens voor die gronden onderworpen aan de speciale wettelijke voorschriften, ten aanzien van elke soort uitgevaardigd, als de reglementen op de particuliere landerijen, en die op de nitgifte van domeingrond in erfpacht of opstal ${ }^{4}$.

Wat de stilzwijgende onderwerping van den inlander, met be-

1 Vergl. artt. 1319, 1339 Ind. B. W. = artt. 1355, 1375 Ned. B. W., en zie Nederburgh, t. a. p., p. 75 .

2 Vergl. Nederburgh, t. a. p., p. 48 en vv. Bij de argumenten, door dien schrijver aangehaald voor de toepasselijkheid van bedoelde ordonnantie op Inlanders, kan nog gevoegd worden het voorschrift van art. 21 daarvan.

s Vergl. Eindresumé, dl. I, p. 4.

4 Men vindt die reglementen met de wijzigingen, welke zij later hebben ondergaan, vermeld in den Regeeringsalmanak voor Ned. Ind., en toegelicht in de bekende Handleiding tot de kennis van het staats- en administratief recht van Ned. Ind. door Prof. Mr. J. de Louter, 4de druk, p. 598 en vv. Op de rechtsvragen, waartoe zij aanleiding geven, afgescheiden van hun verband met het Inlandsche recht, meen ik in dit opstel niet te mogen ingaan. 
trekking tot alle hier bedoelde gronden, aan het Indische Burgerlijk Wetboek betreft, zoo zal men die onderwerping intusschen niet verder mogen uitstrekken dan de evenbedoelde beginselen van het internationaal privaatrecht vorderen. Men zal dus naar het Indische Burgerlijk Wetboek moeten beoordeelen, wat onroerend goed is ${ }^{1}$, den omvang en den inhoud van het zakelijke recht, de beperkingen daarvan in het algemeen belang en dat van naburige erven ${ }^{2}$, de wijze van verkrijging of verlies ${ }^{3}$, den aard en de gevolgen van het bezit, de wettelijke kracht en werking eener overeenkomst het goed betreffende, den vorm en de voorwaarden der gerechtelijke uitwinning, en de wijze om dat goed met zakelijke lasten te bezwaren of het voor schuld te verbinden. Daarentegen zal het goed in quaestie wederom naar het recht van den inlander worden beoordeeld, wanneer het als deel van zijn vermogen fungeert, bv. bij het erfrecht, de bevoegdheid om daarover te beschikken, enz. ${ }^{4}$ De praktijk is, voor zooverre mij bekend, met deze beginselen in overeenstemming. Nimmer is bv. betwist, dat de inlandsche eigenaar van een particulier land dit met hypotheek kan bezwaren, ofschoon zijn nationaal recht die instelling niet kent, noch omgekeerd, dat zoodanig land bij overlijden van den inlandschen eigenaar tusschen diens erfge-

1 De vraag, wat onroerend goed is, ten opzichte van de niet volgens Ind. Stbl. 1834 no 27 ingeschreven perceelen, blijft door het inlandsche recht beheerscht. Vergl. Nederburgh, t. a. p., p. 49. De stelling van den heer Mr. M. C. Piepers (Tijdschr. Het R. in N. I., dl. XLVII (1886), p. 280, 281), dat, door de ordonnantie van Ind. Stbl. 1834 No 27 , stilzwijgend het inlandsche recht ten aanzien van de vraag, wat onroerend goed is, in het algemeen zoude zijn afgeschaft, gaat m. i., op de door den heer Nederburgh aangevoerde gronden, te ver.

2 Verkeeren die naburige erven niet in denzelfden rechtstoestand, d. w. z. worden op het eene inlandsche, en op het andere Europeesche zakelijke rechten uitgeoefend, zoo heeft men ten aanzien der servitutes legales een nieuw rechtsconflict, dat wederom moet worden opgelost naar dezelfde beginselen, als men in een analoog geval zoude huldigen tusschen twee erven, waarvan bv. het eene in Nederland en het andere in België of Duitschland ligt.

$s$ Bv. de verjaring. Het inlandsche recht, in overeenstemming met het Moham. medaansche, kent de acquisitieve verjaring niet. Zie ben. $\S 8$.

4 Vergl., voor hetgeen hier omtrent het internationaal privaatrecht wordt medegedeeld, Mr. T. M. C. Asser: Schets van het internationaal privaatrecht, p. 66 en vv., en Diephuis: Het Nederl. Burg. Regt, dl. I, p. 70 en vv. Verwerpt men met sommigen de leer, dat art. 17 Alg. Bepp. v. N. I. (= art. 7 Ned. Alg. Bepp.) de in de laatste plaats door mij vermelde restrictie toelaat, zoo zal men die restrictie ook niet ten aanzien van den inlander in quaestie kunnen aannemen. Vergl. Opzoomer: Aanteekening op de wet houdende algemeene bepalingen van wetgeving, p. 150 . 
namen moet worden vedeeld, naar de voorschriften van den Islâm, en niet naar die van het Indische Burgerlijk Wetboek.

Hetzelfde geldt mutatis mutandiș voor de aan inlanders toebehoorende schepen, waarvan eigendomstitels volgens Ind. Stbl. 1834, No 27 bestaan.

De in de tweede plaats door onze wet aangegeven oorzaak van niet-toepasselijkheid der godsdienstige wetten, volksinstellingen en gebruiken, namelijk de strijd met algemeen erkende beginselen van billijkheid en rechtvaardigheid, kan men zeggen, dat ten aanzien van het vermogensrecht niet in aanmerking komt. Zoowel de voorschriften van de Moḥammedaansche wet, als de specifiek Javaansche instellingen hieromtrent, laten zich bijna allen even goed vereenigen met de natuurlijke begrippen van billijkheid en rechtvaardigheid, als die van ons burgerlijk en handelsrecht. Waar dit ten aanzien van een enkel voorschrift niet het geval is, zoo heeft men te doen met een gevolg van de bepalingen omtrent het personenof staatsrecht, bv. de slavernij of de beperkende bepalingen, waaraan ongeloovigen zijn onderworpen; maar het vermogensrecht zelf is daarvan gemakkelijk principieel af te scheiden. Het inlandsche recht, Mohammedaansch of niet, moge niet zoo ontwikkeld zijn als het onze; het moge tal van instellingen, in eene Europeesche maatschappij onmisbaar, gelijk de verjaring en de hypotheek, ontberen, dit alles is nog geene reden om het als onbillijk of onrechtvaardig te qualificeeren.

Daarentegen is op geen enkel gebied van het privatrecht door onzen wetgever zoozeer ingegrepen als ten aanzien van het vermogensrecht, ofschoon dit desniettegenstaande in hoofdzaak inlandsch is gebleven. De gedane grepen, hoe gewichtig ook op zich zelf, blijven steeds uitzonderingen, in verhouding tot het geheel, van ondergeschikt belang. In de volgende bladzijden zal dit bij de behandeling der verschillende onderwerpen blijken. Hier wijs ik er slechts op, dat bij de bekende ordonnantie, te vinden in Ind. Stbl. $1855 \mathrm{~N}^{\circ} 79$, op alle met inlanders gelijkgestelde personen, de zoogenaamde Vreemde Oosterlingen, ook wanneer zij den Mo!̣ammedaanschen godsdienst belijden, met enkele uitzonderingen zijn toepasselijk verklaard het geheele tweede, derde en vierde Boek van het Indische Burgerlijk Wetboek, benevens het Indisch Wetboek van Koophandel en het Reglement op de Burgerlijke Rechtsvordering. Bovendien worden, volgens art. 9 dier ordonnantie, ten opzich te van de toepassing daarvan, ook als Vreemde Oosterlingen beschouwd 
alle inlanders, die zich buiten het gewest, waarvan zij afkomstig zijn, ophouden, buiten de leiding der plaatselijke hoofden, en zonder zich met de plaatselijke inheemsche bevolking te hebben vermengd. Een niet minder belangrijke en verreikende greep werd in het inlandsche vermogensrecht gedaan door de zoogenaamde Agrarische Verordeningen, als uitvloeisel van de Agrarische Wet (Ind. Stbl. 1870 No 55) tot stand gekomen.

Er bestaat echter nog een andere, niet op de wet, maar op den feitelijken toestand berustende factor voor de toepassing van het Europeesche privaatrecht ten aanzien van verbintenissen en zakelijke rechten op den inlander, in stede van zijn nationaal recht. Evenals in elk land ter wereld, geeft ook op Java en Madoera de massa der bevolking zich over het geheel weinig rekenschap van dit gedeelte van het recht. Iedereen stelt er belang in te weten, welke zijne verhouding is tot zijne vrouw en zijne kinderen, wie zijne eventueele erfgenamen zijn, of van wie hij zelf eventueel zal moeten erven. Maar, wanneer men den stand der landbouwers met opzicht tot de agrarische toestanden uitzondert, is het getal gering van hen, die zich in alle opzichten rekenschap geven van de rechtsgevolgen hunner handelingen, welke het vermogen betreffen. Men weet, dat, als men iets leent, men het moet teruggeven; dat, als men iets koopt, men het moet betalen; dat, als men eigenaar is, men aanspraak heeft op het bezit met uitsluiting van anderen; maar verder dan deze algemeenheden gaat het rechtsbewustzijn van slechts weinige personen. Of bv. er verschil bestaat tusschen bruikleen en verbruikleen ten aanzien van den eigendomsovergang; of het risico van eene gekochte zaak overgaat door het contract dan wel door de levering; of er verschil bestaat in gevolgen tusschen juridisch en natuurlijk bezit, enz., zijn vragen, waarvoor ook ten onzent alleen in een zeer beperkten kring van Nederlanders belangstelling wordt aangetroffen. Bij de mingegoeden komen trouwens degelijke quaesties in de praktijk niet voor. Deze oorzaken werken natuurlijk in den Archipel, nog sterker dan in West-Europa, om het algemeene rechtsbewustzijn ten opzichte van verbintenissen en zakelijke rechten zwak te doen blijven, en dewijl, vóór de inlandsche rechtbanken op Java en Madoera, partijen in den regel van rechtsgeleerden bijstand verstoken zijn, vindt men in het hier aangevoerde eene gereede verklaring, waarom, ten opzichte van die onderwerpen, in rechten zooveel minder beroep wordt gedaan, hetzij op de Moḥammedaansche wet, hetzij op de specifiek inlandsche afwijkingen 
van die wet, dan met betrekking tot het familie- en erfrecht het geval is. Daaruit laat zich ook verklaren, dat Europeesche schrijvers over inlandsche toestanden ons zooveel meer mededeelen omtrent het familie- en erfrecht, dan omtrent het vermogensrecht. Het bewustzijn omtrent het eerste leeft bij grooten en geringen, en valt in het oog, zoodra men zich in de inlandsche maatschappij beweegt; dat omtrent het tweede is, als men de agrarische verhoudingen uitzondert, iets waarnaar men moet zoeken.

De inlandsche rechtbank, voorgezeten door een Europeesch ambtenaar, is uit den aard der zaak geneigd om, waar door partijen zelf geen beroep op hun speciaal recht wordt gedaan, het er maar al te dikwijls voor te houden, dat het eene zaak geldt, niet bij de godsdienstige wetten, volksinstellingen en gebruiken geregeld, en welke dus, volgens de laatste alinea van art. 75 Reg. Regl., beoordeeld en beslist moet worden naar de beginselen van het voor Europeanen geldende privatrecht. Wel is waar is deze handelwijze principieel onjuist, en zoude de rechtbank verplicht zijn in zoodanig geval ambtshalve te onderzoeken, wat het voor den inlander geldende recht vordert; maar de vele werkzaamheden, waarmede, zoo niet alle, dan toch de meeste landraadsvoorzitters zijn belast, maken het niet zelden onmogelijk van elke zaak - soms van zeer gering geldelijk belang — eene wetenschappelijke studie te maken. Wegens het over het algemeen zwakke rechtsbewustzijn der bevolking ten aanzien van de onderwerpen, welke het hier geldt, vindt de zooeven omschreven methode bij de inlandsche leden der rechtbank zelden tegenspraak, en men kan dan ook niet ontkennen, dat zij uit een practisch oogpunt lang niet zoo verwerpelijk is, als zij op theoretische gronden schijnt ${ }^{1}$. De persoon, die door zijn ambt nog het meest geroepen zoude zijn, om zich tegen de overdreven toepassing van Europeesche beginselen van privatrecht te verzetten, is natuurlijk de Pangoeloe; maar, aannemende dat deze altijd een voldoend ontwikkeld en onafhankelijk persoon is, zoo heeft hij toch slechts eene

1 In zijne redevoering, gehouden in de vergadering van het Indisch Genootschap van 7 Januari 1896 , p. 19, zeide nog de heer Mr. J. H. Abendanon: „Dit laatste”, namelijk het nemen tot richtsnoer van de algemeene beginselen van het Europeesche privaatrecht, ,is het plechtanker der practijk". De uitspraak is in het algemeen zeker waar; doch de geachte rechtsgeleerde had er m. i. moeten bijvoegen, dat die "practijk", met hoe goede bedoelingen soms ook gevolgd, in strijd is met de wet en met den regel: curia novit jus. 
adviseerende stem, en komt hij in den regel bijna uitsluitend op voor het doctrinaire Mohammedaansche recht, maar zeer zelden voor de specifiek inlandsche instellingen. Bij de Raden van Justitie worden de appellen van de vonnissen der inlandsche rechtbanken meestal door rechtsgeleerde raadslieden voorgebracht, en in den regel ook nauwgezetter behandeld, al ware het slechts wegens de grootere geldelijke - belangen en het geringer aantal. Daar wordt dan ook veel op inlandsch recht beroep gedaan, en dat recht toegepast. Van verreweg de meeste vonnissen der.inlandsche rechtbanken wordt echter natuurlijk geen hooger beroep aangeteekend. De cassatie is, gelijk reeds herhaaldelijk werd betoogd, voor de handhaving van het inlandsche materieele privaatrecht een absoluut deugdeloos middel ${ }^{1}$.

In het bovenstaande ligt de verklaring, hoe, door een samenloop van omstandigheden, het Europeesche recht ten aanzien van verbintenissen en zakelijke rechten op weg is om op Java en Madoera langzamerhand door gewoonte voor den inlander eene belangrijke rol te gaan vervullen, ja zelfs in zijn rechtsbewustzijn te worden opgenomen. In het wezen der zaak heeft men hier te doen met gelijksoortige oorzaken, als welke in de Middeleeuwen de receptie van het Romeinsche recht in Europa, speciaal omtrent verbintenissen en zakelijke rechten, hebben te weeg gebracht, namelijk onvoldoendheid van het nationale recht voor de behoeften van een meer ingewikkeld maatschappelijk verkeer, grootere ontwikkeling van het vreemde recht, en den invloed van juristen, die hunne studie an de hand van het vreemde recht hebben gemaakt.

Intusschen is tegen dien, ik zoude bijna zeggen officieelen, stroom van Europeesch recht, vooral in de laatste 25 jaren een krachtige stroom van meer zuiver Moḥammedaansch recht merkbaar. Ten gevolge van de gemakkelijker geworden communicatie met Mekka neemt het getal van hen, die in de heilige stad het juridische en theologische onderwijs hebben gevolgd, meer en meer toe. De in den Archipel gezaghebbende Arabische werken, speciaal de juridische, zijn allen reeds te Caïro, te Mekka of elders in de Levant gedrukt, en die uitgaven zijn zoo goedkoop, dat zij onder het bereik van bijna elken welgestelden inlander vallen. Zij vinden dan ook op Java en Madoera een ruim debiet; terwijl vroeger de Ara-

1 Zie o. a. de praeadviezen van nu wijlen de heeren Hulshoff Pol en Keiser in den eersten jaargang van de Handelingen der Ned. Ind. Jur. Ver., dl. I, p. 247 en vv. 
bische juridische werken, slechts in handschrift bestonden, en alleen reeds wegens hun hoogen prijs door slechts weinigen konden worden aangeschaft. Ook de kennis der Arabische taal wordt, deels door dezelfde oorzaken, deels door de grootere uitbreiding der Arabische koloniën, althans langs Java's Noordkust, langzamerhand meer algemeen, dan oudtijds het geval was. Dit alles komt natuurlijk aan de populariteit der zuiver Moḥammedaansche rechtsbeginselen ten goede, en wel in het bijzonder onder dat gedeelte der bevolking, hetwelk buiten de inlandsche ambtenaarswereld staat, maar zich met handel of industrie erneert, en, evenals overal ter wereld, ook op Java en Madoera het meest processen over verbintenissen en zakelijke rechten voert ${ }^{1}$.

De specifiek Javaansche instellingen omtrent het vermogensrecht geraken, ten gevolge van een en ander, hoe langer hoe meer op den achtergrond. Wordt door de partijen vóór den inlandschen rechter op eigen rechtsbeginselen beroep gedaan, zoo is het, althans op de hoofdplaatsen en groote centra van bevolking, in den regel op de voorschriften van de Mohammedaansche wet. Alleen waar het dorpsverband en het grondbezit in het spel zijn, ziet men, vooral in Midden-Java, den inlander ook dikwijls een beroep doen op zijne, niet in de Moḥammedaansche wet beschreven, aloude volksinstellingen en gebruiken.

Behoudens hetgeen hierboven omtrent den invloed van het Europeesche privaatrecht werd opgemerkt, kan men tegenwoordig het dogmatische Mohammedaansche recht omtrent verbintenissen en zakelijke rechten reeds als voorheerschend beschouwen op de groote handelsplaatsen langs Java's Noordkust. Te Batavia en in de Bataviasche Ommelanden spreekt dit verschijnsel zich het sterkst uit. Overigens is het Moḥammedaansche recht ten deze het meest in het bewustzijn der bevolking doorgedrongen in Bantam, de PreangerRegentschappen, de afdeeling Buitenzorg en Krawang, gelijk mede op het eiland Madoera, doch het minst in de Vorstenlanden, Banjoemas, Bagelen, Kadoe en Kediri. In Madioen hebben de talrijke godsdienstscholen ook indirect veel bijgedragen, om de Arabische rechtsboeken populair te maken. In West-Java zijn een aantal Arabische rechtstermen als hạq, milk, hibah, waçîjah, ḥarîm, enz., zij het soms in, naar de inlandsche uitspraak ge-

1 Vergl. nog over dit punt mijn opstel: Het Kruis tegenover de Halve Maan, in de Gids, afl. Oktober 1890 , p. 81 en v., en Nederburgh, t. a. p., p. 61. 
wijzigden vorm, bij het gros der bevolking, zelfs op het platte land, in gebruik. Aan de beteekenis van dit feit wordt niet te kort gedaan door de omstandigheid, dat de mindere man, die termen gebruikende, zich zelden volledig rekenschap geeft van hunne juridische waarde ${ }^{1}$. In dit opzicht staat hij trouwens wederom gelijk met den burgerman in Nederland, die, als hij van "recht", "eigendom", "schenking", "legaat", of "aanhoorigheid" spreekt, bijna nooit eene in alle opzichten juiste en volledige voorstelling heeft van de juridische begrippen, welke bedoelde woorden vertegenwoordigen in ons positieve recht ${ }^{2}$.

In bovenstaande opmerkingen ligt de sleutel tot het juist verstand van hetgeen in dit opstel verder zal worden vermeld. Vooreerst volgt er uit, dat omtrent geen onderdeel van het privaatrecht van den inlander zoo groote onbestemdheid heerscht als omtrent de instellingen, welke hier zullen worden behandeld, de agrarische toestanden uitgezonderd. Niet alleen immers is het recht te dien aanzien zelve zwevend; dit toch is met elk recht het geval, dat grootendeels op gewoonte berust. Maar de zaak wordt hier nog nevelachtiger dan bij het familie- en erfrecht, omdat men inderdaad à priori in vele gevallen moeielijk kan nagaan, welk recht door de inlandsche rechtbank zal worden toegepast op eene bepaalde handeling. In de tweede plaats zijn de bronnen, speciaal voor de verbindtenissen, schraal; zij zijn ten minste aanmerkelijk schraler dan voor het familie- en erfrecht. Het bekende Eindresumé bevat niet slechts voor de kennis van het grondbezit, maar ook voor die der verbintenissen vele gegevens. Men vergete echter niet, dat het in 1867 en 1868 gehouden onderzoek, hetwelk aan dit werk ten grondslag strekte, hoofdzakelijk een agrarisch onderzoek was, dat het verbintenissen, niet met de agrarische toestanden verband houdende, buiten beschouwing liet; dat bedoeld onderzoek op belangrijke gedeelten van Java en Madoera geene betrekking had, en dat het vooral de stedelijke bevolking zoo goed als met stilzwijgen voorbijging. En nu zijn het natuurlijk juist de groote centra van bevolking, waar het rechtsbewustzijn omtrent verbintenissen het meest ontwikkeld is, tengevolge van het meer levendige verkeer.

1 Vergl. Eindresumé, dl. I, p. 2.

${ }^{2}$ De vermoedelijke oorzaak van het verschil in receptie van het Mohammedaansche recht in de onderscheidene deelen van Java en Madoera heb ik elders uiteengezet. Zie o. a. mijne Mohammedaansche geestelijkheid, p. 35 en vv. 
In een en ander is ten slotte ook de verklaring gelegen, waarom ik mij in de volgende bladzijden nog meer dan in mijn opstel over het familie- en erfrecht, tot hoofdpunten zal bepalen. Zij, die in het land zelf in de gelegenheid zijn de inlandsche rechtsbegrippen te-onderzoeken of toe te passen, zullen mij verplichten door mijn arbeid aan te vullen, en op hunne beurt bekend te stellen, in hoeverre mijne algemeene resultaten plaatselijk al dan niet uitzondering lijden. Zal eenmaal het privaatrecht voor deu inlander worden gecodificeerd, zoo is een dergelijke voorarbeid onontbeerlijk.

\section{§ 2. Verbintenissen.}

Omtrent de algemeene leer der verbintenissen, gelijk mede omtrent het karakter, de vereischten of de gevolgen der afzonderlijke overeenkomsten, kan men zeggen, dat de voorschriften van de Moḥammedaansche wet vrij wel in het rechtsbewustzijn der bevolking zijn ingedrongen. Trouwens de inlanders, die over dergelijke abstracte begrippen nadenken - uit den aard der zaak niet velen - hebben hunne wijsheid ten deze aan de geschriften der Arabische juristen ontleend, behalve natuurlijk voor zooverre zij bij ons ter schole zijn geweest. Herhaaldelijk vindt men dan ook rechterlijke uitspraken gepubliceerd, waarin in dit opzicht zuiver Moḥammedaansch recht werd toegepast, zonder vooraf te overwegen, of die toepassing overeenkwam met de plaatselijk geldende begrippen ${ }^{1}$. Men beschouwt dit blijkbaar als iets, dat van zelf spreekt. Ook de Javaansche wetten der Vorstenlanden gaan ten deze van de beginselen van den Islâm uit. Men zie bv. Nawålå Pradåtå artt. 30,31 en Anggĕr Sadåså artt. 9, 27 omtrent de verantwoordelijkheid voor ongelukken door iemands huisdieren veroorzaakt en omtrent onrechtmachtige daden, en Anggĕr Sadåså art. 32 over de ontbinding eener overeenkomst wegens wanpraestatie ${ }^{2}$.

1 Zie, onder meer, de rechterlijke uitspraken gepubliceerd in het Tijdschr. Het Recht in Ned. Ind., dl. XIX (1861), p. 305 en v., en in het Ind. Weekbl. v. h. Recht, Nos 1023 en 1624.

2 De artikelen van de Javaansche wetten der Vorstenlanden zijn in dit opstel geciteerd naar de vertaling, voorkomende in het Tijdschrift: Het Recht in N. I. dl. I (1849), p. 327 en vv. 
Slechts ten aanzien van enkele punten, de algemeene leer der verbintenissen betreffende, wijkt het inlandsche rechtsbewustzijn op Java en Madoera beslist van de voorschriften der Moḥammedaansche wet af. Zoo zal geen inlander op die eilanden er aan denken, dat wijn, sterke drank, benevens sommige afbeeldingen van menschen of dieren, en sommigen zijner nationale muziekinstrumenten, als door den Islâm verboden, buiten het handelsverkeer zijn. Daarentegen kent de Islâm wederom niet, als oorzaak van onttrekking van roerende of onroerende goederen aan het handelsverkeer, dat deze, om godsdienstige redenen, bv. omdat zij tot verblijf van geesten strekken, niet mogen worden aangeraakt of betreden. In het Javaansch heet deze toestand: angkĕr, in het Maleisch en en Soendaasch: boejoet ${ }^{\mathbf{1}}$. Over de afwijkingen ten aanzien van de persoonlijke bevoegdheid om zich te verbinden van minderjarigen, onder curateele gestelden, slaven en ongeloovigen, gelijk mede over de bereddering van insolvente boedels, en van die van afwezigen, heb ik elders het noodige gezegd ${ }^{2}$. Eene belangrijke afwijking van het Moḥammedaansche recht ten aanzien van de algemeene leer der verbintenissen, is verder, dat deze in ons geheele rechtstreeksche gebied te niet gaan door verjaring. $\mathrm{Bij}$ Ind. Stbl. $1832 \mathrm{~N}^{\circ}$. $4 \mathrm{l}$ is namelijk de extinctieve praescriptie voor alle ingezetenen van Nederlandsch-Indië geregeld, en, ofschoon deze regeling voor Europeanen en met hen gelijkgestelden in 1848 is komen te vervallen, tengevolge van de nieuwe voorschriften omtrent dit onderwerp, in het Burgerlijk Wetboek vervat, zoo is die regeling toch voor inlanders blijven bestaan ${ }^{3}$. Eindelijk is op Madoera en in de Madoereesche streken van Java het wedden en

1 Vergl. Veth: Java, dl. III, p. 132, benevens de Mal. Jav. en Soend. woordenboeken s. v.

2 Vergl. Familie- en erfrecht, p. 455, 464, 479 en vv., 495-500 en 503.

3 Dat het in de bedoeling van den wetgever lag de voorschriften van Ind. Stbl. 1832 No 41 ook op niet-Europeanen te doen slaan, blijkt uit het slot dier publicatie, waar vertaling in de inlandsche en Chineesche talen gelast wordt. Voor Vreemde Oosterlingen, ook die den Islâm belijden, is de regeling komen te vervallen, ten gevolge van de toepasselijk-verklaring op hen van de voorschriften van het Ind. Burg. Wb., bij Ind. Stbl. 1855 No 79 . In de Vorstenlanden geldt Ind. Stbl. 1832 No 41 niet voor Inlanders, volgens art. 27 al. 2 Reg. Regl.; maar geldt Ind. Stbl. 1855 No 79 wel voor Moḥammedaansche en andere Vreemde Oosterlingen, omdat deze aldaar de rechtstreeksche onderdanen van het Gouvernement zijn, volgens de bestaande kontrakten met de inlandsche vorsten. Zie over deze aangelegenheid nog het arrest van het Hoog Gerechtshof dd. 31 Januari 1850 (Tijdschr. Het Recht in N.-I., dl. III (1850), p. 256 en vv.). 
uitloven van prijzen bij wedrennen van hoornvee in gebruik; terwijl op geheel Java en Madoera bij hanen- en audere dierengevechten wordt gewed en prijzen worden uitgeloofd, alles in strijd met het Mohammedaansche recht ${ }^{1}$. Daarentegen is het weder in overeenstemming met den [slâm, dat de Javanen van ouds niet, gelijk de Maleiers en Boegineezen, een afzonderlijk recht hebben voor de verbintenissen uit de scheepvaart voortspruitende. Ten gevolge echter van het slotartikel der Bepalingen op de huishouen tucht op de koopvaardijschepen (Ind. Stbl. 1573 No. 119) zijn inlanders, op Europeesch getuigde schepen dienstdoende, op eene kleine uitzondering na, van rechtswege aan Boek II, Titel IV van het Indische Wetboek van Koophandel onderworpen.

\section{§. Koop ${ }^{2}$.}

Het koopcontract is de overeenkomst, welke in het maatschappelijk verkeer, ook op Java en Madoera, als de meest voorkomende en de belangrijkste moet worden aangemerkt. "Koopen" heet in het Javansch: toekoe (N) toembas (K), in het Soendaasch: beuli, en in het Maleisch: bĕli. "Verkoopen" is in het Javaansch : adol (N) sadé of wadé (K), in het Soendaasch en Maleisch: d joewal. Van deze grondwoorden zijn ook de termen voor "kooper" "verkooper", "koop", "verkoop", enz. afgeleid. De afwijkingen van de Mohammedaansche wet betreffen vooreerst den vorm der overeenkomst. Onroerende goederen, waarop door inlanders zakelijke rechten naar het Europeesche Burgerlijk Wetboek worden uitgeoefend, kunnen, in verband met hetgeen reeds ter zake werd uiteengezet $^{3}$, niet worden verkocht dan met inachtneming van de regelen, in het Europeesche recht voor den overgang van zoodanige goederen gesteld. Intusschen worden ook bij den verkoop van erfelijk individueel bezeten onroerende goederen door den inlander veelal

1 Vergl. Fath al-Qarîb, p. 655; Sollewijn Gelpke: Gegevens voor eene nieuwe landrente-regeling, in de Ind. Gids, Jaarg. 1886 p. 433; J. L. van Gennep: Bijdrage tot de kennis van den Kangéan-Archipel, in dit Tijdschr., 6de Volgreeks, dl. II, p. 98 en v.

2 Vergl. mijn opstel in den Feestbundel aangeboden aan wijlen den Hoogleeraar P. J. Veth, ter gelegenheid van zijn tachtigsten geboortedag, p. 28 en vv.

${ }^{3}$ Zie boven p. 86 en v. 
formaliteiten in acht genomen, bij de Moḥammedaansche wet niet voorgeschreven. Speciaal is dit het geval bij den verkoop van saw ah's en vischvijvers. In den regel namelijk worden zoodanige goederen slechts verkocht in tegenwoordigheid van getuigen, als hoedanig veel het dorpshoofd met één of meer oudsten of, waar deze ontbreken, met één of meer leden van het dorpsbestuur fungeeren. De getuigen moeten in elk geval vooraf de ligging van de verkochte goederen opnemen. Vooral in Bantam en de PreangerRegentschappen, maar overigens ook elders, komt het voor, dat hun door ééne der partijen of door beiden een klein geschenk in geld wordt gegeven, ten teeken dat zij het gebeurde geconstateerd hebben. In de meeste streken zijn de getuigen bij de geheele handeling tegenwoordig; in enkele streken alleen bij het betalen der koopsom.

Het opmaken van schriftelijke verkoopbewijzen, door partijen en getuigen onderteekend, zij het met een kruisje, is in West-Java ten aanzien van onroerende goederen algemeen. In Midden- en Oost-Java, gelijk mede op Madoera, is het een bekend, maar niet zoo algemeen verspreid gebruik. Ook registratie dezer verkoopbewijzen komt in vele streken voor: hier geschiedt zij door het districtsbestuur, elders door den districts- of regentschapspangoeloe, elders weder door andere inlandsche autoriteiten. Bij den verkoop van onroerende- goederen, welke voor den inlander eene groote waarde vertegenwoordigen, is, vooral op of in den omtrek van plaatsen, waar afzonderlijke notarissen gevestigd zijn, langzamerhand het gebruik in zwang gekomen notarieele verkoopbewijzen te doen opmaken. Het meest is dit gebruik in zwang in de residentie Batavia ten opzichte van gronden, waarop het zoogenaamde inlandsche erfpachtsrecht, krachtens Ind. Stbl. $1836 \mathrm{~N}^{\circ} 19$, wordt uitgeoefend, welk recht, gelijk men weet, slechts in naam, maar niet in aard van het erfelijk individueele bezits- of gebruiksrecht elders verschilt. De notarieele koopovereenkomsten, welke ik hier op het oog heb, worden evenals de inlandsche notarieele testamenten, volgens art. 19 Alg. Bepp., alleen wat den vorm betreft door het Europeesche recht beheerscht, maar niet ten aanzien van den materieelen inhoud, tenware partijen zich daarbij uitdrukkelijk voor de overeenkomst in quaestie aan het Europeesche recht hebben onderworpen, volgens de artt. 11 en 13 Alg. Bepp. Dit zoude hier natuurlijk geoorloofd, maar bij testamenten ongeoorloofd zijn, omdat de materieele inhoud van 6e Volgr. III. 
een testament met het familie- en erfrecht verband houdt, en dus van openbare orde is ${ }^{1}$.

Ook bij roerende goederen zijn schriftelijke verkoopbewijzen, zoodra het zaken van waarde geldt, algemeen in gebruik. Bij het opmaken dezer verkoopbewijzen, soerat katĕrangan, pipil of pèl geheeten, worden echter minder formaliteiten in acht genomen dan bij die, welke voor onroerend goed worden afgegeven. In den regel bestaan zij in eene verklaring van het dorpshoofd of van den dorpsschrijver, dat de kooper het voorwerp van den verkooper gekocht heeft, met vermelding dat zij van deze omstandigheid, hetzij door eigen wetenschap, hetzij door getuigenis van anderen, kennis dragen. Eene korte omschrijving van het voorwerp en eene vermelding van den bedongen prijs worden veelal bijgevoegd. Geldt het vee, zoo bestaat de omschrijving in een signalement, bv. in eene vermelding van den vorm, de richting of de lengte der hoorns van buffels. Het briefje strekt dan den kooper tot bewijs, dat hij op wettige wijze eigenaar is geworden, en dat, als later mocht blijken, dat het goed aan een ander toebehoort dan den verkooper, de kooper, in elk geval niet als medeplichtige kan worden vervolgd, bijaldien de verkooper de zaak door misdrijf mocht hebben verkregen.

Tot goed begrip van de beteekenis dezer briefjes bij roerende goederen, dient nog te worden in herinnering gehracht, dat de Islâm noch onzen regel kent, dat bij die goederen bezit voor titel geldt, noch de acquisitieve verjaring, en dat de inlandsche begrippen ten aanzien van beide punten met het dogmatische Mohammedaansche recht overeenkomen. De instelling der koopbriefjes van roerende goederen is op Java en Madoera blijkbaar zeer oud; zij komt reeds in het wetboek Soerjå Ngalam voor ${ }^{2}$.

Van grootere beteekenis zijn uit een economisch oogpunt de beperkingen der contractsvrijheid, vooral in Midden-Java, bij den verkoop van erfelijk individueel bezeten gronden, door gemeentelijke instellingen, en wel speciaal ten aanzien van sawah's, maar ook ten aanzien van erven en andere gronden, ofschoon in mindere mate ${ }^{3}$. Als een gevolg van die beperkingen kan men de instelling

1 Zie boven p. 85, en vergl. Familie- en erfrecht p. 510, 511; Eindresumé, dl. I, p. 48 en vv.; Sollewijn Gelpke, t. a. p., p. 577, 719, 720; Handelingen der N. I. Juristenvereeniging, Jaarg. 1887, dl. I, p. 20,21 ; Nalezing, p. 314.

2 Vergl. Handel. der N. I. Juristenvereeniging, Jaarg. 1886, dl. I, p. 132 ; Soerjå Ngalam (Bijdragen, Nieuwe Reeks, dl. VI), p. 26.

3 Vergl., over die instellingen volgens ons staatsrecht, Familie- en erfrecht, p. 478,479 . 
beschouwen, dat verkoop van grond doorgaans niet buiten voorkennis, en dikwijls niet zonder toestemming van het dorpshoofd mag plaats hebben ' ${ }^{2}$ In de streken, waar geene inlandsche gemeenten als rechtspersonen bestaan, bv. in de Vorstenlanden, komen dergelijke beperkingen natuurlijk niet voor.

De hier bedoelde beperkingen zijn vooreerst dezelfde als die, welke bij de behandeling van het huwelijksgoederenrecht werden angestipt ${ }^{2}$. Zoo zal, waar voor het grondbezit inwonerschap der gemeente gevorderd wordt, de verkoop van erfelijk individueel bezeten grond aan niet-ingezetenen slechts kunnen plaats hebben onder de voorwaarde van vestiging in de gemeente. Dit inwonerschap nu wordt in verreweg de meeste streken van Midden-Java, gelijk mede in Pasoeroean voor het saw a h-bezit gevorderd; terwijl ook op Madoera en in de Madoereesche streken van Oost-Java dezelfde instelling sporadisch wordt aangetroffen. Van het erfelijk individueel bezit van tĕg al's, tuinen, boomgaarden en vischvijvers zijn hier en daar eveneens zij, die niet in de gemeente wonen, uitgesloten, en bijna overal is dit het geval ten aanzien van woonerven. Ja zelfs is het bezit van woonerven in Madioen en Kediri algemeen, en voorts in zeer vele gemeenten van Bagelen, benevens eenige in Japara, Rembang, Soerabaja en elders, in dier voege beperkt, dat ook ingezetenen niet meer dan één woonerf in de gemeente mogen bezitten, zoodat iemand, die reeds een woonerf heeft, geen tweede er bij mag koopen, zonder zich van het eerste te ontdoen ${ }^{3}$. Er zijn echter ook nog andere beperkingen, welke bij den verkoop in aanmerking komen. Om als erfelijk bezitter te kunnen optreden, is het een noodzakelijk vereischte, dat men in staat zij den grond zelf te bebouwen, of ten minste in staat zij voor de bebouwing te zorgen. Minderjarigen en ongehuwde vrouwen kunnen dan ook door koop geen grondbezit verwerven, niet alleen, wat de eerstgenoemden betreft, omdat zij de bevoegdheid missen zich te verbinden, maar ook, en daarvan is natuurlijk hier alleen sprake, omdat zij niet als bezitters kunnen optreden. Hun voogd kan dus evenmin hun ververmogen in grondbezit beleggen. Voorts werken de gemeentelijke instellingen omtrent de dienstplichtigheid beperkend. Men kan geen

\footnotetext{
${ }^{1}$ Vergl. Sollewijn Gelpke, t. a. p., p. 719.

2 Vergl. Familie- en erfrecht, p. 477 en v.

3 Vergl. Eindresumé, dl. I, p. 19, 20, 116, 144, 145, 160, 189; Sollewijn Gelpke, t. a. p., p. 527.
} 
grondbezit verkrijgen, als men niet in staat is zich van de daarop klevende persoonlijke diensten te kwijten, en daar nu de dienstplichtigheid in vele gemeenten, zoo niet geheel dan toch grootendeels op de sawah-bezitters drukt, zoo is daardoor implicite verkoop van sawah's aan vele personen uitgesloten, die, ofschoon overigens bekwaam om te verkrijgen, voor dienstpraestatie ongeschikt zijn. Slechts in West-Java staan de gemeentelijke instellingen ten deze aan den overgang van grond niet in den weg, eenige weinige gemeenten uitgezonderd, ofschoon ook daar de dienstplichtigheid in verreweg de meeste streken aan het grondbezit is verbonden. Bij de woonerven is de voorwaarde van voor de behoorlijke bewoning te zorgen, schijnbaar gemakkelijk na te komen, daar bv. de voogd van een minderjarige het erf desnoods ten diens behoeve zoude kunnen verhuren; doch in de praktijk is het niet altijd gemakkelijk een huurder te vinden. Verhuur van erven kan men namelijk zeggen, dat op het platteland, althans als industrieel bedrijf, onbekend is ${ }^{1}$.

Het sterkst doet de invloed der gemeentelijke instellingen omtrent het grondbezit zich gelden in die gemeenten, waar zelfs de verkoop van erfelijk individueel bezeten grond, aan wien ook, verboden is. Ofschoon bedoelde gemeenten de uitzondering vormen, zoo wordt toch in vele andere het verkoopen van zijn grond voor eene handeling gehouden, welke, tenzij om gewichtige redenen van persoonlijken aard, uit een zedelijk oogpunt geene aanbeveling verdient. De aanleiding, om tot den verkoop van grond over te gaan, is trouwens in den regel geldgebrek. Het bepaalde verbod van verkoop komt het meest voor ten opzichte van bouwgronden, maar ook, ofschoon sporadisch, ten aanzien van woonerven of vischvijvers. De meerderheid der gemeenten, waar zoodanig verbod bestaat, liggen in Midden-Java, maar sommigen ook in West- en Oost-Java. Het verbod van verkoop schijnt hier en daar samen te hangen met het algemeen bestaande bewustzijn, dat men geen eigenaar van den grond is, doch dien slechts in gebruik heeft van het Gouvernement ${ }^{2}$. Verkoop van erfelijk individueel bezeten grond aan niet tot de eigenlijke inlandsche bevolking behoorende personen, is verboden bij

1 Vergl. Eindresumé, dl. I, p. 18, 115, 143, 163, 167, 197; Sollewijn Gelpke, t. a. p., p. 577,579 .

2 Vergl. Eindresumé, dl. I, p. 45 en vv., 115, 124, 162, 197; Sollewijn Gelpke, t. a. p., p. 719, en mijn opstel: Het eigendomsrecht van den staat op den grond op Java en Madoera, in dit Tijdschrift, 5de Volgreeks, dl. VI (1891), p. 26. 
Ind. Stbl. $1875 \mathrm{~N}^{\circ} 179$, en evenmin kunnen naar mijne meening, op grond van algemeene rechtsbeginselen, de inlandsche erfpachtsrechten, uitgeoefend op den grond behoorende tot de zoogenaamde particuliere landerijen bewesten de rivier Tji Manoek, aan andere personen dan eigenlijke inlanders worden verkocht, ofschoon de jurisprudentie op dit punt niet constant is ${ }^{1}$. De rechten op communaal bezeten bouwgronden, en de contractueele rechten der opgezetenen in de Vorstenlanden, of op de particuliere landerijen beoosten de rivier Tji Manoek, laten, wegens hunnen aard, geen verkoop van den grond, maar slechts cessie van de persoonlijke aanspraken toe. Bij gebruiksrechten, aan het ambt, de bediening of de qualiteit verbonden, is zelfs cessie ongeoorloofd. Dat overigens verkoop van erfelijk individueel bezeten grond, gevolgd door levering, geen eigendom overdraagt, maar slechts het eigenaardige inlandsche zakelijke recht op den grond, is te elementair om er bij stil te staan.

Omtrent den afzonderlijken verkoop der a c e ssoria van onroerend goed bestaat geene andere afwijking van den Islâm, dạn dat de beperkingen van de Mohammedaansche wet, ten aanzien van den verkoop van onrijpe vruchten zonder den boom, of van een onrijpen, te velde staanden oogst, niet zijn gerecipieerd. Verkoop van te velde staanden oogst, vóór het begin der rijpwording, komt intusschen zelden voor; maar des te meer de verkoop der vruchten van een bepaalden boom, vóór dat zij de teekenen van rijpwording vertoonen, ja zelf vóór dat de bloesems zijn afgevallen, en zonder de door de Islâm uitdrukkelijk gestelde voorwaarde van onmiddellijke weghaling ${ }^{2}$.

De voorwaardelijke verkoop in dien zin, dat de kooper de bevoegdheid zal hebben om binnen zekeren tijd de overeenkomst te vernietigen, hetzij omdat de waar hem niet bevalt, hetzij om andere redenen, is wederom op Java en Madoera in den Moḥammedaanschen vorm in gebruik, behoudens dat men zich niet gebonden acht aan den in den Islâm aangenomen max im u m-termijn van drie dagen ${ }^{3}$.

Eene bijzondere soort van voorwaardelijken koop, waarvan de Arabische rechtsbronnen geene melding maken, maar welke op geheel Java en Madoera dagelijks voorkomt, is dat iemand aan een rondgaand handelaar (Jav. pĕpårå of bakoel, Soend. Mal. tjĕ ng kaw) zekere roerende goederen afstaat, onder het beding dat

1 Vergl. Familie- en erfrecht, p. 503; Nalezing, p. 314, en zie meer over dit punt, beneden, $\S 13$.

${ }^{2}$ Vergl. Minhâdj aț-Ṭâlibîn, di. I, p. 402 en v.

s Vergl. Minhâdj aț-Tâlibîn, dl. I, p. 371. 
laatstgenoemde binnen een bepaalden termijn, ò den bedongen prïs moet betalen, ò de goederen in natura moet teruggeven. Wat van beiden hij doen zal, staat ter zijner keuze. De handelaar heeft dus de bevoegdheid de goederen te verkoopen, en wat bij dien tweeden verkoop meer verkregen zal worden, dan de bij den eersten verkoop bedongen prijs, is zijne winst. In het Maleisch is de gewone formule, waarmede dit contract gesloten wordt: $d j i k a l a w$ lakoe, bawa oewang, tidaq lakoe, poelang barang. De verkooper blijft eigenaar, totdat de goederen zijn van de hand gezet. Het is voornamelijk de détail-handel in edelgesteenten, welke op deze wijze wordt gedreven, en wel in hoofdzaak door vrouwen; maar ook ten opzichte van andere goederen is de overeenkomst veel in zwang. Zij is geheel het contractus aestimatorius van het Romeinsche recht, en de begrippen van den inlander, omtrent de vereischten en gevolgen, komen dan ook overeen met hetgeen ter zake de Romeinsche rechtsbronnen ons leeren. Het contract wordt evenzeer dikwijls in omgekeerden vorm gesloten, namelijk zoodanig dat hij, die iets koopen wil, aan een handelaar opdraagt, hem dit tegen een bepaalden prijs te bezorgen. Kan de handelaar dan de goederen voor lageren prijs bekomen, zoo is het verschil ten zijnen voordeele. Wil men in het Hollandsch een naam aan de overeenkomst geven, zoo zoude die van "inlandsch commissiekontrakt" m. i. nog de meest passende zijn. Intusschen komt het ook veel voor, dat de handelaar slechts tegen een zeker loon tracht de voorwerpen aan den man te brengen of te koopen, en dan is er natuurlijk slechts eene overeenkomst van geremunereerde lastgeving aanwezig, ja soms zelfs eenvoudig huur van diensten ' ${ }^{\prime}$.

De verkoop met recht van wederinkoop kan zich, volgens den Islâm, alleen voordoen in den vorm van het zooeven bedoelde

1 Vergl. over dit kontrakt eene belangrijke beschikking van den President van den Landraad te Batavia, te vinden in het Indische Weekblad van het Recht, Jaarg. 1887, No 1244. Deze beschikking heeft wel is waar op Chineezen betrekking; maar voor inlanders zullen de daarin voorkomende beschouwingen eveneens moeten gelden. Vergl. ook Winter: Javaansche zamenspraken, dl. I, p. $49,59,65$, en Windscheid: Lehrbuch des pandektenrechts, dl. II, p. 400 en vv. De door mij gevolgde constructie van het contractus aestimatorius als eene soort van voorwaardelijken verkoop, is, naar ik meen, reeds sedert lang in Europa algemeen aangenomen. Ofschoon de Arabische juristen het contract niet opzettelijk behandelen, was het toch reeds ten tijde van Mohammad in Arabië in zwang. Vergl. Bochârì: Çahịh (ed. Krehl), dl. II, p. 52, 53. 
beding, dat ééne der partijen, in cas u de verkooper, de bevoegdheid heeft om na zekeren termijn, doch niet langer dan na drie dagen, de handeling door eene éénzijdige verklaring te niet te doen, waarna de waar en de prijs over en weder moeten worden gerestitueerd. Men noemt dit beding in het Arabisch: chijâr a sj-sja rt , letterlijk: "bedongen keuze". Het staat in karakter gelijk met de overige rechtsmiddelen tot eenzijdige vernietiging van een gesloten koopcontract, welke rechtsmiddelen de Arabische juristen in het algemeen "keuzen" (chijâr) noemen, en waartoe zij o. a. onze actio redhibitoria en onze actio quanti minoris brengen Deze zoogenaamde "bedongen keuze" is echter uitdrukkelijk verboden bij de overdracht van zaken aan het woekerverbod onderworpen, en is, wanneer zij voor langer dan drie dagen is overeengekomen, wat het meerdere betreft, van rechtswege nietig. Deze voorschriften der Mohammedaansche wet nu worden op Java en Madoera eenvoudig voor niet geschreven gehouden, evenmin trouwens als men er zich aan het woekerverbod in het algemeen veel stoort ${ }^{1}$. De Islâm verklaart ten overvloede nietig alle gefingeerde rechtshandelingen, waardoor men eenige ongeoorloofde handeling of oorzaak zoude trachten te verbergen. De regel: plus valet quod agitur quam quod simulate concipitur, wordt door de Arabische juristen streng doorgevoerd ${ }^{2}$. Intusschen wijken ook in dit opzicht de op Java en Madoera gangbare begrippen van den Islâm af, en de verkoop met recht van wederinkoop

1 Zie hierover nader, beneden, $\$ 6$.

2 Vergl. Minhàdj aț Ṭâlibîn, dl. I, p. 369 en volgg. Alleen dan, wanneer men het doel kan bereiken door een ander, zij het niet in de wet met name genoemd, contract te sluiten, en het doel op zich zelf en in beginsel niet verboden is, laat de Islâm eene uitzondering op dezen regel toe. Zoo kan men bv. het verbod om een langeren termijn dan drie dagen voor den wederinkoop te bedingen, ontduiken door niet van "verkoop" te spreken, maar, gelijk in Turkije geschiedt, van „ontruiming bij de betaling" (fir âgh bil-wa fâ). Vergl. Aristarchi-Bey: Législation Ottomane, dl. I, p. 158 en vv., 182 en vv. en 274 en vv. Een dergelijk voorbeeld ten aanzien van het mozâra' a h-kontrakt, vindt men in den Fath al-Qarîb, p. 393. De bewoners van Java en Madoera noemen echter, gelijk wij zagen, de overeenkomst bepaald: „verkoop", en dit contract laat het beding van wederinkoop slechts toe voor drie dagen, ofschoon op zich zelf en in beginsel een recht van ontbinding eener overeenkomst op langeren termijn in den Islâm geene verboden zaak is. Daarentegen zoude bv. het beding van ribâ of woeker, op welke wijze ook geformuleerd, wel nietigheid der handeling ten gevolge hebben, omdat ribâ op zich zelf en in beginsel eene der grootste zonden is, welke de Islâm kent. Zie ben. $\S 6$. 
is de meest voorkomende vorm, waarin men zijne woekertransacties omzet, vooral wanneer de woekeraar een Arabier, hadji, of ander als kerksch bekend staand persoon is.

Dit geschiedt op tweeërlei wijzen. In de eerste plaats verkoopt de woekeraar an den geldopnemer eenig voorwerp, welk ook, op crediet, en hij koopt het onmiddellijk weder à contant van hem terug. Het verschil is dan de rente. Dit is dus hetgeen men in Europa, toen de woekerwetten nog algemeen in zwang waren, het mohatra-kontrakt noemde ${ }^{1}$, welk woord, als afgeleid van het Arabische mochâțarah, reeds dadelijk de Oostersche herkomst van de handeling verraadt. De handeling is dan ook niet slechts op Java en Madoera, maar evengoed in andere Mohammedaansche landen bekend. De naam mochâțarah, letterlijk: "kansovereenkomst", laat zich verklaren door het feit, dat de geldschieter aldus geene enkele zakelijke zekerheid erlangt van door den geldopnemer op de overeengekomen termijn betaald te zullen worden, en derhalve het gevaar van latere insolventie van den debiteur op zich neemt. De wederinkoop is natuurlijk bij deze handeling niet alleen eene bevoegdheid van den verkooper; maar hij is daartoe ook verplicht; want de wederpartij heeft alleen de zaak gekocht, met het doel dat hij ze om gereed geld aan den oorspronkelijken eigenaar zoude kunnen terugverkoopen ${ }^{2}$.

In de tweede plaats kan de verkoop met recht van wederinkoop een vermomd pandeontract opleveren, en dit begrijpen de inlanders zelf zoo goed, dat zij alsdan spreken van "pandverkoop" (Jav. adol (N) of wadé (K) gaḍé, Soend. djoewal sanḍa of ga dé, Mal. djoewal sanda of gadai). De geldopnemer verkoopt bij deze overeenkomst aan den geldschieter eene hem toebehoorende zaak, met voorbehoud van de bevoegdheid om die zaak later terug te koopen (Mal. Jav. Soend. tĕ boes), hetzij voor denzelfden prïjs, hetzij voor een hoogeren. Het eerste beding heeft veelal plaats, wanneer de zaak tot de zoodanigen behoort, die vruchten afwerpen, bv. een grondstuk, een huis, een stuk vee, enz.; het tweede, wanneer het niet-productieve bezittingen geldt, bv. een diamant. $\mathrm{Bij}$ het beding van wederinkoop voor denzelfden prijs strekken feitelijk de vruchten der zaak tot vergoeding van het gebruik van het ontvangen kapitaal, d.w. z. tot rente; bij het beding van

1 Vergl. Windscheid, t. a. p., dl. II, p. 44; Dalloz: Répertoire, v o c e Vente, No 54.

2 Vergl. de redevoering van den heer F. Fokkens in de vergadering van het Indisch Genootschap van 4 Febr. 1896, p. 38. 
wederinkoop voor een hoogeren prijs, vervult het meer te betalen geld dezelfde functie. Zaken, welke door het gebruik te niet gaan, zijn natuurlijk voor deze overeenkomst niet vatbaar. Ten einde de vruchten, welke de zaak afwerpt, gemakkelijker te innen dan door eigen exploitatie, en soms ook om inkomsten te erlangen van eene zaak, welke uit haren aard niet productief is, bv. van een diamant, verhuurt de kooper die niet zelden onmiddellijk weder aan den verkooper, hetzij tegen geld, hetzij, ingeval van een grondstuk, tegen een evenredig deel van den oogst. Somtijds stelt de verkooper zoodanige verhuur als voorwaarde voor den verkoop, wanneer hij er prijs op stelt het feitelijk bezit van zijn goed te blijven behouden, bv. wanneer hij er an gehecht is als aan een erfstuk, dan wel omdat hij als landbouwer van de opbrengst van zijn aldus verkochten akker moet leven. In streken, waar schriftelijke verkoopbewijzen in zwang zijn, wordt, indien van den verkoop met recht van wederinkoop, gevolgd door verhuur, geene speciale akte is opgemaakt, de koopbrief van den debiteur door den crediteur onder zich gehouden, als bewijs dat hij eigenaar is geworden ${ }^{1}$. Veelal wordt onder deze omstandigheden het goed, zelfs niet voor een oogenblik, onder de macht van den kooper gebracht, hetgeen niet wegneemt, dat dan toch de eigendom is overgaan krachtens het constitutum possessorium, hetwelk ook als eene inlandsche instelling is aan te merken ${ }^{2}$. Indien bij de overeenkomst een bepaalde termijn (Mal. Jav. Soend. djandji) is gesteld, waarop van het reeht van wederinkoop moet worden gebruik gemaakt, zoo heeft de verkooper niet de bevoegdheid om op dien termijn te anticipeeren, evenmin als de kooper hem daartoe dwingen kan, doch gaat, door het ongebruikt laten voorbijgaan van dien termijn, de bevoegdheid om weder in te koopen onherroepelijk verloren voor den verkooper. Dit laatste is ook het geval, indien de bevoegdheid tot wederinkoop tot op zekeren termijn is verleend. Wat overigens den termijn, zoowel in dit als in het vorige geval, betreft, van eene beperking daarvan is geen sprake, noch tot drie dagen, gelijk wij zagen dat de Islâm vordert, noch tot de vijf jaar van het Indische Burgerl. Wetboek ${ }^{3}$. Ja zelfs kunnen partijen de uitoefening van het recht van wederinkoop in het geheel aan geen termijn binden. In

\footnotetext{
1 Zie boven p. 97 en v.

${ }^{2}$ Vergl. het vonnis van den Landraad te Batavia dd. 24 Febr. 1889 (Ind. Weekbl. v. h. Recht No 1347).

${ }^{3}$ Art. $1520=$ art. 1556 Ned. Burgl. Wb.
} 
dat veel voorkomende geval kan de verkooper, of kunnen zijne erfgenamen of rechtverkrijgenden, hunne bevoegdheid tot in het oneindige doen gelden, en blijft de verplichting om den wederinkoop te dulden, als een zakelijke last op het goed kleven, in wiens handen het zich ook moge bevinden. De last van wederinkoop belet namelijk niet, dat de kooper het goed op nieuw verkoopt. Omgekeerd kan in zoodanig geval de verkooper van zijn recht van wederinkoop, zoodra hij wil, gebruik maken, tenzij de kooper een termijn heeft bedongen, waarbinnen geen wederinkoop kan plaats hebben. Zoodanig beding is zeer gewoon bij productieve goederen. Bij bouwgronden neemt men zelfs stilzwijgend aan, dat de verkooper niet van zijn recht tot wederinkoop mag gebruik maken tegen den zin van den kooper, indien laatstgenoemde niet ten minste éénen oogst van den grond heeft genoten, noch op een oogenblik dat de wederinkoop den kooper niet te voorziene schade zoude berokkenen, bv: vóór den oogst van het door hem geplante gewas. Een en ander doet op nieuw het verband met het pandcontract uitkomen. Het doel van beiden is geldleening tegen zekerheid; in het eene geval in den vorm van bevoegdheid om op het goed zijne pretensie te verhalen; in het andere in den vorm van eigendom onder eene ontbindende voorwaarde ${ }^{1}$. In beide gevallen wil de geldschieter soms zekerheid hebben van gedurende eeń bepaald tijdverloop zijn kapitaal productief te maken. Met het oog op den langen, of zelfs, gelijk wij zagen, onbepaalden termijn, waarover de verkoop met recht van wederinkoop niet zelden loopt, is het niet te verwonderen, dat daarbij, speciaal wanneer het onroerende goederen geldt, nog meer schriftelijke, ja zelfs notarieele, bewijzen in zwang zijn dan bij den gewonen verkoop ${ }^{2}$.

Waarom men soms tot den verkoop met recht van wederinkoop, en soms tot het verpanden zijne toevlucht neemt, is niet altijd duidelijk, daar, gelijk straks blijken zal, laatstgenoemde overeenkomst economisch ongeveer dezelfde gevolgen heeft, en alleen juridisch, d.w. z. in den aard van het bezit van den geldschieter, daarvan verschilt. Slechts kan men in het algemeen opmerken, dat, wanneer de opgenomen som geheel of bijna gelijk staat met de waarde van het goed, er doorgaans verkoop met recht van weder-

1 Vergl. Dalloz, t. a. p., voce Nantissemement, No 217.

2 Vergl. Eindresumé, dl. I, p. 52, 127, 166, 200; Veth: De verpanding van akkers op Java, in het Tijdschr. van N. I., Jaarg. 1869, dl. II, p. 75 en vv. ; Sollewijn Gelpke, t. a. p., p. 720 en vv.; Fokkens, t. a. p., p. 36, 37. 
inkoop plaats heeft, en, in het geval van opneming eener geringere som, in pand wordt gegeven. Ook valt het op, dat Arabieren, h a dji 's, en andere als kerksch bekend staande personen, meer van den verkoop met recht van wederinkoop dan van het pandcontract gebruik maken, ofschoon beide overeenkomsten op Java en Madoera in een vorm inheemsch zijn, met de Molıammedaansche wet in strijd '

Over den koop en verkoop tusschen Moḥammedaansche echtgenooten, die tot de Vreemde Oosterlingen behooren, heb ik elders het noodige gezegd ${ }^{2}$.

\section{$\S 4$. HuUr.}

Huur heet in het Javaansch: séwå, en in het Soendaasch en Maleisch: séwa. Deze overeenkomst is, na het koopcontract, voor het maatschappelijke verkeer op Java en Madoera de belangrijkste. Zij wordt gesloten zoowel voor onroerende als voor roerende goederen; terwijl eveneens huur van diensten en aanbesteding in gebruik zijn. Men bezigt alsdan echter niet het woord séwa, maar, bij huur van diensten, in het Javaansch opah (N) of épah (K), en in het Soendaasch en Maleisch oepah of gadjih, met de daarvan afgeleide vormen. Bij aanbesteding bezigt men het woord borong, eveneens met de daarvan afgeleide vormen. Daar men, in overeenstemming met de Moḥammedaansche wet, geen eigenaar behoeft te zijn om te verhuren, kunnen ook personen dit contract sluiten, die niet mogen verkoopen. Zoo mag de pandhouder de hem verpande zaak verhuren, en hetzelfde geldt van de aandeelhebbers in communale velden of de houders van ambtsvelden, voor den tijd van hun genot. Vóór 1863 konden de vertegenwoordigers

1 Vergl. Resumé van Bantam p. 113. De meening van Wilken, dat de verkoop met recht van wederinkoop inderdaad niet anders zoude zijn dan een antichretisch pandrecht aan een termijn gebonden, komt mij niet geheel juist voor, evenmin als de stelling van wijlen dien geleerde, dat het ontbreken van een termijn van inlossing een algemeen en natuurlijk kenmerk van het antichretische pandrecht zoude zijn. Immers worden, althans op Java en Madoera, de beide overeenkomsten, verkoop met recht van wederinkoop en pand, gelijkelijk met en zonder termijn van inlossing gesloten. Vergl. Wilken: Het pandrecht bij de volken van den Indischen Archipel, in dit Tijdschrift, $5^{\text {de }}$ Volgreeks, dl. III (1888), p. 601 en vv. en, voor het karakter der antichrese in het algemeen, Dalloz, t. a. p., voce Nantissement, Nos 2 en 216 en vv.; Code Civil art. 2088. Tegen de gelijkstelling van het Inlandsche pandkontrakt met de antichrese en den verkoop met recht van wederinkoop werd reeds opgekomen door Mr. A. W. C. Verweij. Zie p. 249 en 250 van diens opstel: Over het contractueel pandelingschap, in dit Tijdschrift, $5^{\text {de }}$ Volgreeks, dl. VIII (1893), p. 234 en vv.

2 Vergl. Familie- en erfrecht, p. 477. 
der inlandsche gemeenten de communale velden dier gemeenten ook aan niet-inlanders verhuren; doch bij de ordonnantie, te vinden in Ind. Staatsbl. $1863 \mathrm{~N}^{\circ} 152$, is dit verboden. Daar het verbod slechts op niet-inlanders slaat, en in het algemeen de inlandsche gemeente als rechtspersoon, ook krachtens haar zakelijk gebruiksrecht op de communale velden, tot verhuur daarvan bevoegd moet worden geacht, zoo zal men nog steeds moeten aannemen, dat door haar die velden, hetzij aan andere inlandsche gemeenten, hetzij aan personen behoorende tot de inlandsche bevolking kunnen worden verhuurd, wat de laatsten betreft, behoudens de verbodsbepalingen, voor inlandsche hoofden en ambtenaren uitgevaardigd, omtrent het deelnemen aan landbouw- of andere industrieele ondernemingen binnen het gebied, waar zij gezag uitoefenen. De verhuur van grond behoorende tot het staatsdomein, door inlanders aan niet-inlanders, mag thans trouwens alleen plats hebben overeenkomstig de voorschriften, te vinden in de Indische Staatsbladen van 1871 № 163 , $1879 \mathrm{~N}^{\circ} 209$ en $1894 \mathrm{~N}^{\circ} 52$ en 64 . Volgens art. 1 al. 2 van eerstgenoemde verordening worden die overeenkomsten beheerscht door het Ind. Burg. Wetboek, zoodat wij ze in dit opstel verder buiten beschouwing kunnen laten. Ditzelfde is het geval met de huur van diensten, door dat bij Ind. Stbl. 1879 No 256 de artt. 1601,1602 en 1603 Ind. Burgl. Wb. ${ }^{1}$ op de inlandsche en daarmede gelijkgestelde bevolking in geheel Nederlandsch-Indië zijn toepasselijk verklaard, vermoedelijk omdat deze overeenkomst hoofdzakelijk tusschen inlanders en Europeanen of Vreemde Oosterlingen wordt gesloten. Houdt men dit laatste niet in het oog, zoo moet de maatregel een zonderlingen indruk te weeg brengen. Immers zal, geloof ik, wel niemand tegenspreken, dat de geheele titel van verhuur één der minst gelukkig geslaagden van het Burgerlijk Wetboek is, en dat, van dien min geslaagden titel, juist de afdeeling, welke door evengenoemde artikelen worden gevormd, nog wel het meest vat geeft aan critiek. Nu moge men een voorstander zijn van de toepasselijk verklaring van ons vermogensrecht op den inlander, men zal toch moeten erkennen, dat de logica zoude vorderen in die richting te beginnen met meer voortreffelijke gedeelten daarvan. Als een eigenaardig gebruik bij huur van diensten, speciaal tusschen inlanders en Europeanen, moet worden gewezen op het feit, dat het loon in den regel niet wordt betaald, gelijk

$1=\operatorname{artt} .1637,1638,1639$ Ned. B. Wb. 
tusschen Europeanen onderling, nadat de diensten gepraesteerd zijn, maar vooraf, bij wijze van voorschot, zoo niet geheel, dan toch ten deele. Soms verbergt de vooruitbetaling van het loon eene overeenkomst van geldleening. Een ander eigenaardig gebruik is, dat inlanders en Vreemde Oosterlingen de personen, die zij in hunnen handelsdienst hebben, dikwijls niet in geld beloonen, maar in goederen, welke deze laatsten dan tegen een bepaalden prijs moeten nemen, en zelf moeten trachten aan den man te brengen, willen zij daarvoor geld in handen krijgen. Soms moeten zij dan zelfs goederen tot eene hoogere waarde dan hun loon ontvangen, en moeten zij de getaxeerde waarde in elk geval aan hun meester uitkeeren. Wat zij voor de goederen meer maken, is hun loon. Ook bij de huur van scheepsvolk op inlandsch getuigde schepen is deze combinatie met het contractus aestimatorius in zwang ${ }^{1}$. Het geven van voorschot is ook door het gebruik bijna een natuurlijk gevolg geworden van het contract van aanbesteding, hetwelk overigens geene afwijkingen van de voorschriften van den Islâm oplevert Dit laatste is evenzeer het geval bij de verhuur van roerende goederen. Daarentegen moet langer worden stil gestaan bij de verhuur van onroerend goed.

Wij zagen hierboven ${ }^{2}$, dat inlanders, die onroerende goederen in eigendom volgens het Indische Burgerlijk Wetboek bezitten, bedoelde goederen niet mogen vervreemden dan met inachtneming der formaliteiten, voor den eigendomsovergang van zoodanige goederen voorgeschreven, al zijn bedoelde inlanders overigens niet aan het recht der Europeanen onderworpen. De vraag rijst, of men hetzelfde beginsel zal moeten huldigen bij verhuur van zoodanige goederen, en, daarvan uitgaande, of men de voorschriften omtrent de verhuur van landerijen

1 Vergl. Van Gennep, t. a. p., p. 96, en zie, voor het huren van scheepsvolk op Europeesch getuigde schepen, de reeds hierboven (p. 96) vermelde toepasselijk verklaring van het voor Europeanen geldende recht, bij het slotartikel van Ind. Stbl. 1873 No 119. Dat dikwijls personen in het gezin van hunne ouders, schoonouders, enz. kost en inwoning erlangen, tegen het verrichten van huis- of veldarbeid, zonder juridisch tot dat gezin te behooren, beschouw ik meer als een gevolg van het familie-verband, dan als eene overeenkomst op huur van diensten betrekkelijk. Vooral is deze verhouding in zwang bij schoonzoons, die, wanneer hun de middelen ontbreken om een eigen huishouden te beginnen, bij hunne schoonouders met hunne vrouw blijven wonen. Vergl. C. Poensen: Iets over het Javaansch gezin, in de Meded. v. h Ned. Ind. Gen., dl. XXXI (1887), p. 119, 144, 146 en v.; Dezelfde: Iets over de Javaansche naamgeving en eigennamen, Ibid. dl. XIV (1870) p. 309.

2 Zie p. 86 en v. 
en huizen, vervat in de artt. 1550 en vv. Ind. B. Wb. ' , als op dergelijke huurovereenkomsten toepasselijk zal moeten aanmerken. Zeker zijn vele van de hier bedoelde voorschriften in overeenstemming met de Mohammedaansche wet, en blijkt van geen afwijkend rechtsbewustzijn daaromtrent bij den inlander; maar andere, bv. die omtrent het gevorderd schriftelijk bewijs van het contract, zijn met beiden in strijd, en nu kan men toch moeielijk aannemen, dat de Furopeesche of Chineesche huurder van eenig huis aan laatstbedoelde voorschriften gebonden zoude zijn, eu zijn inlandsche verhuurder niet. Hoe ongerijmd deze consequentie ook is, ik beschouw ze met de wet in de hand volstrekt niet als onverdedigbaar, omdat eene uitdrukkelijke toepasselijk-verklaring op den inlander niet heeft plaats gehad, en de verhuur, als zijnde geene beschikking over een zakelijk recht, moeielijk geacht kan worden stilzwijgend door den rechtstoestand van het goed te worden beheerscht. De zaak wordt nog vreemder, als men zich herinnert, dat de wetgever de verhuur van onroerend goed, waarop slechts het inlandsche recht van erfelijk bezit wordt uitgeoefend, voor zoover die aan niet-inlanders geschiedt, door het Indische Burgerlijk Wetboek laat beheerschen ${ }^{2}$.

Verhuur van bouwgrond heeft plaats, hetzij door geld, hetzij tegen uitkeering van een deel in den oogst. In het eerste geval wordt de huurprijs in den regel vooruit betaald, doch somtijds ook voor een deel vooruit en voor een ander deel wanneer de oogst van het veld wordt genomen. In het tweede geval heeft altijd de voldoening van den liuurprijs op laatstgenoemd tijdstip plaats. Indien niet anders bij het contract bepaald is, blijven de lasten, jegens den lande of de gemeente op den grond klevende, voor rekening van den verhuurder. Verhuur van ander onroerend goed dan bouwgrond, gelijk mede van roerende zaken, geschiedt steeds tegen geld ${ }^{3}$. Tot verhuur van zijne akkers wordt de inlander in den regel gedreven door geldgebrek. Soms is ook gemis van ploegree, of overvloed van bouwgrond, daartoe de aanleiding, ook wel het feit dat men de gemeente voor korteren of langeren tijd wenscht te verlaten. In deze gevallen wordt veelal als huurprijs een deel

$1=$ artt. 1586 en vv. Ned. Burgl. Wb.

2 Zie boven p. 87 en 108.

s Vergl. Eindresumé, dl. I, p. 54, 55, 79, 127, 168, 200; Sollewijn Gelpke, t. a. p., p. 716. In sommige streken wordt de verhuur van bouwgronden voor geld in het Javaansch en Soendaasch speciaal $\mathrm{nglandjak}$ genoemd; maar dit gebruik is niet vast. 
van den oogst bedongen, en ditzelfde kan men ook zeggen van de goederen, welke door de gemeente, door de bezitters krachtens hun ambt, dan wel door de geestelijkheid als waarnemende het bestuur der goederen in de doode hand (Mal. Jav. Soend. wakap, v. h. Arab. wa q f) worden verhuurd als exploitatiemiddel ${ }^{1}$. Is geldgebrek de aanleiding tot verhuur, dan wordt de huurprijs ook steeds in geld voldaan, en worden door het huurcontract niet zelden allerlei andere transacties bedekt. Zoo wordt soms eene geldleening omgezet in een huurcontract met vooruitbetaalden huurprijs; in andere gevallen verbergt de huurovereenkomst eene doorloopende rekening, welke de grondbezitter met zijn leverancier heeft. Zij vervult dan dezelfde economische functie als bij ons de crediethypotheek. In alle die gevallen ziet men ook dikwijls huurovereenkomsten voor zeer langen termijn sluiten, en door den huurder den huurprijs vele jaren vooruit betalen, met bevoegdheid op den verhuurder om, tegen terugbetaling van den ontvangen huurprijs, het contract tusschentijds te ontbinden, hetzij wanneer hem dit goeddunkt, hetzij bv. nadat het verhuurde veld eenınal geoogst zal zijn. Dat dit natuurlijk op het bedrag van den huurprijs nadeeligen invloed uitoefent, behoeft geen betoog ${ }^{2}$.

Het huurcontract, als zijnde, in beginsel althans, slechts een tijdelijke afstand, is aanmerkelijk minder beperkt door gemeentelijke instellingen dan de verkoop. Dit laat zich ook daardoor verklaren dat de verhuurder ten definitieve aansprakelijk blijft voor de lasten, jegens den lande of jegens de gemeente op den grond klevende, ook al neemt de huurder die voor zijne rekening. In het bijzonder kan men overal verhuren aan personen niet in de gemeente gevestigd, en behoeft de verhuurder niet aan de vereischten te voldoen om als grondbezitter in de gemeente op te treden. Daar het doel der overeenkomst is het erlangen van het genot van den grond, spreekt het van zelve, dat de beperking bij verkoop tot personen in staat om den grond behoorlijk aan zijne bestemming te doen beantwoorden, bij verhuur geen zin zoude hebben. Dit alles verklaart, waarom soms aan verhuur, met vooruitbetaling van vele termijnen, de voorkeur wordt gegeven boven verkoop van den grond, ofschoon de latste voordeeliger voor den

1 Vergl. Moḥammedaansche Geestelijkheid, p. 38; Eindresumé, dl. I, p. 81, $86,92,101,102,105,111,132,133,201$.

${ }^{2}$ Vergl. Eindresumé, dl. I, p. 55, 56, 80, 128, 201; Sollewijn Gelpke, t. a. p., p. 714,715 . 
bezitter zoude zijn geweest. In die gevallen weet de huurder wel zulke onereuse bepalingen te maken omtrent de teruggave, dat de bezitter daaraan nimmer kan voldoen, of wel hij laat den bezitter voor nieuwe gelden of goederen, welke hij gedurende den loop van het huurcontract verstrekt, telkens de toezegging doen van huurverlenging. Met het oog op het, wel is waar soms in naam, tijdelijke karakter van de verhuur, wordt het contract veel meer mondeling aangegaan dan het koopcontract. Wordt het schriftelijk aangegaan, zoo geldt daaromtrent $\mathrm{mutatis} m u$ tandis wat omtrent schriftelijke koopovereenkomsten is gezegd ${ }^{1}$.

De verhuur van bouwgronden tegen een deel van den oogst is tweeledig. De huurder kan namelijk als huurprïs eene vaste hoeveelheid van het product afstaan, en dan is de overeenkomst gelijk aan de gewone huur, behoudens dat de huurprijs niet in gemunt geld, maar in natura wordt opgebracht. Bij het meê- of tegenvallen van den oogst heeft in dat geval de verhuurder geen belang. Soms is bij zoodanige huur het beding alternatief: producten of geld, ter keuze van den huurder ${ }^{2}$. Het kan echter ook zijn en dit is de meest voorkomende vorm - dat de huurprijs in een evenredig deel van den oogst bestaat. Zoodanige overeenkomst is, naar het recht van den Islâm, alleen geoorloofd ten aanzien van aanplantingen van twee soorten van vruchtboomen, dadelpalmen en wijnstokken ${ }^{3}$, welke op Java en Madoera niet in aanmerking komen. Ten aanzien van een akker is de overeenkomst slechts bestaanbaar, als aanhangsel van die omtrent dadel- of druivenaanplantingen, d. w. z. ten aanzien van de ledige stukken grond tusschen de boomen gelegen. Bovendien moet in dat geval het zaad door den verhuurder worden verstrekt ${ }^{4}$. Het inlandsche contract nu wijkt ten deze principieel van de Moḥammedaansche wet af. Het wordt namelijk als eene zelfstandige overeenkomst gesloten, het meest ten aanzien van sawah's, maar ook ten aanzien van andere bouwgronden, ja zelfs ten aanzien van vischvijvers. Wanneer tuinen of boomgaarden aldus worden verhuurd, wordt noch aan de beperking tot dadelpalmen of wijnstokken, noch aan het maken van

1 Zie boven p. 97 en v., en vergl. Eindresumé, dl. I, p. 54, 56, 81, 128, 132, 168, 177, 200, 202; Sollewijn Gelpke, t. a. p., p. 716.

9 Vergl. Eindresumé, dl. I, p. 55, 79, 80.

s Natuurlijk onderstellen de juristen van den Islâm, dat men geene wijngaarden heeft om van de druiven wijn te maken, doch om dezen als rozijnen te confijten.

4 Vergl. Minhâdj aț-Ṭâlibîn, dl. II, p. 143 en vv. 
een speciaal beding ten aanzien der open plekken tusschen de boomen gedacht. Dikwijls levert de verhuurder het zaad; maar even dikwijls doet zulks de huurder. Partijen zijn ten deze absoluut vrij, evenals trouwens in hunne andere bedingen betreffende de exploitatie, bv. omtrent de vraag of de huurder de lasten, op den grond klevende jegens den lande of de gemeente, voor zijne rekening zal nemen, wie het ploegvee zal verstrekken, of de verhuurder een gedeelte van de bewerking zal verrichten, enz. De hier genoemde factoren beheerschen ook de vraag, welk deel van den oogst of, bij vischvijvers, van de opbrengst, de verhuurder voor zich bedingt. Andere factoren te dien aanzien zijn: de vruchtbaarheid van den grond, de meerdere of mindere moeite aan de bewerking verbonden, en de gemakkelijke afzet der producten. Meestal is het aandeel, hetwelk de verhuurder bedingt, $\frac{1}{2}$ of $\frac{1}{3}$ dan wel $\frac{2}{3}$; maar ook andere fracties komen in bijzondere gevallen voor, bv. $\frac{1}{4}$ of $\frac{3}{4}$, ja zelfs $\frac{1}{5}$ of $\frac{4}{5}$. Naar den noemer der door den verhuurder bedongen fractie wordt het aldus verhuren van grond genoemd, en wel in het Javaansch: maro, mĕrtĕloe enz. (N) of malih, mĕrtigå, enz. (K), in het Soendaasch: maro, martiloe, enz., en in het Maleisch: mĕmpĕrdoewa, mĕmpĕrtiga, enz. Eene modificatie van het contract is nog, dat de huurder het geheele veld beploegt en beëgt, waarna het in twee stukken wordt verdeeld, waarvan de huurder en de verhuurder elk één voor eigen kosten en risico bezaait of beplant en oogst ${ }^{1}$.

Eene eigenaardige soort van huurovereenkomst is die, welke tot voorwerp heeft gronden met de daarop gelegen dorpen en de heerlijke rechten op de in die dorpen wonende bevolking, of, gelijk men gewoonlijk zegt, de "dorpsverhuur", omdat de perceelen worden genoemd naar de daarop gelegen vestigingen.

Deze huurovereenkomst, welke natuurlijk slechts door inlandsche vorsten, of apanage-houders, d.w.z. hoofden of grooten kan worden gesloten, is met den Islâm volslagen onvereenigbaar. De vorst kan, volgens de Mohammedaansche wet, alleen de gronden verhuren, welke tot het vrije staatsdomein behooren; over de gronden zijner onderdanen, onverschillig of die in eigendom of in erfelijk gebruiksrecht worden bezeten, heeft hij geene beschikking. De belastingen en andere praestatiën aan den lande, waartoe de onderdanen ge-

1 Vergl. Eindresumé, dl. I, p. 57, 81, 82, 128, 129, 203.

6 e Volgr. III. 
houden zijn, kunnen alleen worden afgestaan aan particulieren, bij wijze van iqțâ' of concessie, welke concessie wel is waar in den regel een remuneratief karakter draagt, maar desniettegenstaande principieel van verhuur verschilt ${ }^{1}$. De op Java en Madoera voorkomende dorpsverhuur hangt uit den aard der zaak samen met den privaatrechtelijken eigendom van den grond, welke aan de vorsten toekomt; terwijl daaruit tevens te construeeren is de bevoegdheid tot verhuur door de personen, aan wie de vorst als apanage een deel van den grond tijdelijk heeft afgestaan ${ }^{2}$. Ook de voormalige Oost-Indische Compagnie heeft zich, als getreden in de rechten der inlandsche vorsten, steeds op dit standpunt gesteld, en hare regenten als door haar geapanageerd beschouwd.

De dorpsverhuur kwam dan ook oudtijds in Midden- en Oost-Java en op Madoera voor; doch Daendels heeft hieraan in ons rechtstreeksch gebied een einde gemaakt, en aan regenten en andere hoofden het verhuren, op dien yoet, van stukken van hun gebied uitdrukkelijk verboden ${ }^{3}$. In de Madoereesche vorstendommen heeft de dorpsverhuur opgehouden bij de invoering aldaar van ons rechtstreeksch gezag, namelijk in Pamakassan in 1857, in Soemenep in 1883 en in Bangkallan in $1885^{4}$. Die verhuur bestaat dus thans nog alleen in de Vorstenlanden van Midden-Java; doch ook aldaar zijn sedert 1830 Vreemde Oosterlingen als huurders geweerd ${ }^{5}$. $\mathrm{Nu}$ waren het juist Chineezen en Arabieren, die, zoowel vroeger in de Vorstenlanden als op Madoera, en, vóór Daendels, ook in 's Compagnie's gebied, van de dorpshuur werk maakten, en de bevolking op allerlei wijzen wisten uit te zuigen. Wel is waar ligt het in den aard van het huurcontract, dat de huurder geene meerdere rechten kan uitoefenen dan aan den verhuurder toekomen; maar, wegens de onbestemdheid der op het gewoonterecht gegronde verplichtingen van den bevolking, de onverschilligheid van velen harer hoofden, en het algemeene gebrek aan controleerend per-

1 Vergl. Mâwardî: al-Ahkkâm as-Solțânîjah (ed. Enger), p. 332.

2 Zie meer hierover in mijn reeds aangehaald opstel: Het eigendomsrecht van den staat, enz. p. 1 en vv.

s Zie den Staat der Nederl. O. I. Bezittingen, p. 10, 46; Mr. J. A. van der Chijs: Nederlandsch-Indisch Plakaatboek, dl. XIV, p. 750 en vv.; De Jonge: De opkomst van het Nederl. gezag op Java, dl. VIII, p. LXVII.

- Vergl. Ind. Stbl. 1858 No $54 ; 1883$ No $242 ; 1885$ No 144.

5 Wettelijk werd hun eerst de bevoegdheid tot inhuren van dorpen ontnomen bij art. 1 van Ind. Stbl. 1857 No 116. 
soneel, was den huurder feitelijk alles jegens de bevolking geoorloofd, zoolang niet oproer of eenig geruchtmakend geval van knevelarij het Europeesch gezag dwong tusschenbeide te komen.

Wat den toestand in de tegenwoordige Vorstenlanden betreft, zoo valt op te merken, dat de dorpsverhuur aan inlanders nog geheel door de nationale instellingen wordt beheerscht, maar dat die aan Europeanen of daarmede gelijkgestelden door onzeñ wetgever reeds in 1857, en laatstelijk in 1884, aan een nauwkeurig toezicht van het bestuur en aan tal van beperkende bepalingen is gebonden, de uiteenzetting van welke bepalingen intusschen niet tot ons onderwerp behoort ${ }^{1}$.

De inlandsche dorpshuurder, of liever pachter ${ }^{2}$, heet b ěk ěl, soms met bijvoeging van het woord pa madjĕggan (N) of pamaossan (K), d.w. z. "die pacht opbrengt", om hem te onderscheiden van den zoogenaamden bĕkĕl maron $(N)$ of b. malihan $(\mathrm{K})$, d. i. de administrateur van den apanagehouder, indien deze zijn grond niet verpacht, maar voor eigen rekening en risico laat exploiteeren, gelijk mede van den bĕkĕl ngiras, d.i. de opzichter van den apanagehouder, indien deze zelfs persoonlijk de exploitatie van zijn grond in hauden heeft gehouden ${ }^{3}$. Heeft de běkĕl een groot perceel gepacht, zoo noemt men hem dĕmang, ronggo of ngabèhi, al naarmate van den omvang zijner onderneming ${ }^{4}$. Van de pachtovereenkomst wordt eene schriftelijke acte opgemaakt, welke den naam van piag ěm draagt, en waarin de bijzondere voorwaarden van het contract, de verhouding tot den verhuurder, d. w. z. tot den loe rah, letterlijk: "het onmiddellijke

1 Zie Ind. Stbl. 1857 No $116 ; 1872$ No $211 ; 1884$ Nos $9,10,86,189 ; 1886$ No $48 ; 1891$ No 255.

${ }^{2} \mathrm{Bij}$ de dorpsverhuur gebruikt men in den regel in het Javaansch niet het woord séwå (zie boven p. 107), en de daarvan afgeleide vormen, maar spreekt men van padjĕg (N) of paos (K), d. i. „pacht”, en de daarvan afgeleide vormen.

${ }^{3}$ De opdracht der administratie aan een ander, en à fortiori de persoonlijke exploitatie, komen slechts bij kleine apanages voor. De groote apanagehouders, evenals de vorsten, exploiteeren hun grond door middel van dorpsverhuur. De vorsten verhuren daarbij alleen groote perceelen.

4 De gewone uitgestrektheid van een pachtperceel is hoogstens 3 djoeng; sommige perceelen zijn echter veel grooter. De djoeng bevat 4 bahoe of karjå, d. w. z. de hoeveelheid land, welke door 4 gezinnen (tjatjah) kan worden bebouwd, of op andere wijze geëxploiteerd. De oppervlakte der djoeng's verschilt dus naar de terrein-omstandigheden. De ngabèhi's zijn de grootste pachters, dan volgen de ronggo's, daarna de děmang's, en eindelijk de gewone běkẽl's. 
hoofd", van den bĕk ĕl 1, de opbrengsten, waartoe deze verplicht is, en diens verhouding tot de bevolking van het perceel geregeld zijn, voor zoover een en ander niet voortvloeit uit de Javaansche wetten of algemeen bekende instellingen. Daar de b ĕk ěl over zijn perceel tevens eene zekere politie-macht uitoefent, moet van elke nieuwe pachtovereenkomst worden kennis gegeven aan de plaatselijke inlandsche bestuurshoofden ${ }^{2}$. In het algemeen kan natuurlijk de verpachter aan den b ĕkĕl geene meerdere rechten afstaan, dan hij zelf heeft. De pacht betreft dus den grond, welke tot het dorp behoort (Jav. boemi déså (N) siti du o esoen $(\mathrm{K})$ ), met de heerlijke rechten op de bevolking, overeenkoinstig de bestaande gebruiken, maar niet de praestatiën, waartoe de bevolking verplicht is jegens den vorst als zoodauig, d.w. z. de zoogenaamde nĕgårå- (N) of nĕgari (K) -diensten, en de belastingen. Zelfs wanneer de vorst een stuk grond aan een bĕkĕl verpacht, zijn deze praestatiën niet in de overeenkomst begrepen ${ }^{3}$. In de pacht is mede niet begrepen de verplichting van de bevolking om den vorst of den geapanageerde met zijn gevolg te onderhouden, wanneer deze zich tijdelijk op het perceel bevindt ${ }^{*}$, noch de bijzondere opbrengsten en diensten aan den verhuurder verschuldigd bij gelegenheid van algemeene of private festiviteiten, alles overeenkomstig de wetten en instellingen des lands 5. Gedurende. den loopenden pachttijd mag de bĕk ĕl niet van het perceel door den verhuurder worden afgezet, en evenmin mag de b ĕk ĕl dit verlaten, tenzij natuurlijk in geval van wettelijke ontbinding wegens wanpraestatie van één van beide kanten, dan wel indien de bĕkĕl, wegens niet-vervulling zijner plichten als agent van

1 Woont de geapanageerde niet op het perceel, maar op de hoofdplaats, zoo spreekt men van loerah tabon, of alleen van tabon.

2 De běkěl heeft dus, behalve zijne privaatrechtelijke verplichtingen en rechten, nog publiekrechtelijke functies; doch de beschrijving dezer laatsten valt buiten het kader van dit opstel.

3 De běkĕl is intusschen gehouden om te zorgen, dat ook de hier bedoelde verplichtingen door de bevolking worden nagekomen.

${ }^{4}$ Het recht van den landheer om, vergezeld van zijn gevolg, zijne onderhoorigen te bezoeken, en zich dan door hen te laten onderhouden, bestond oudtijds met. even betreurenswaardige gevolgen in Schotland en Ierland. Zie H. S. Maine: Early history of institutions, $3^{\text {de }}$ druk, p. 141.

${ }^{5}$ De nadere uiteenzetting van een en ander zoude hier, waar slechts rechtsbeginselen geformuleerd worden, misplaatst zijn; alleen moet ik ook ten deze opmerken, dat bedoelde opbrengsten, diensten en onthalen in de practijk grootendeels naar zuivere willekeur worden gevorderd. Zie boven, p. 114, 115. 
het openbaar gezag, dit laatste noodzaakt tusschenbeide te komen. Behalve in geval van de straks te vermelden wanbetaling van de pacht, blijft, zelfs bij ontslag van den b ĕkĕl wegens wanpraestatie, enz., het plantsoen, waarvoor reeds pacht betaald is, d. i. de zoogenaamde alib ${ }^{1}$, zijn eigendom. Bij overlijden van den bĕkĕl gaan zijne contractueele rechten en verplichtingen op zijne kinderen over. De pachtcontracten mogen in normale gevallen slechts loopen van den tijd dat de velden onbebouwd zijn, of althans de jonge rijstplantjes nog niet zijn overgeplant, totdat de oogst van het veld is weggehaald. Anders moet de nieuwe pachter daarvoor schadevergoeding aan zijn voorganger betalen. Ook deze te velde staande oogst heet alib. Bij perceelen, welke gedeeltelijk uit rijstvelden, gedeeltelijk uit andere bouwgronden bestaan, regelen de termijnen zich naar den rijstbouw. De pacht kan zoowel in geld als in producten worden bedongen; maar in het eerste geval heeft toch de verhuurder steeds het recht betaling in producten te vorderen. De betaling geschiedt in twee halfjaarlijksche termijnen, namelijk bij het feest van de geboorte van Moḥammad, den zoogenaamden Garĕbĕg Moeloed, en bij gelegenheid van het feest van het ophouden der groote vasten, den zoogenaamden Garĕbĕg Poewåså (N) of G. Siam (K) ${ }^{2}$, bij welke feesten de bĕkĕl tevens in persoon zijne opwachting bij den verhuurder moet komen maken, en hem de pacht over het verloopen halfjaar moet komen brengen ${ }^{3}$. Bij wanbetaling op die termijnen, wordt de schuld van den bĕkĕl voor de eerste 8 dagen met 50 pCt. verhoogd. Daarna nog niet betalende, klimt de boete naar een in Soerakarta en Djokjakarta eenigszins verschillend, maar in elk geval zeer onereus tarief, en wordt, na ommekomst van ongeveer drie maanden, de bĕkĕl ontzet, zonder dat hij eenig recht, zelfs op den te velde staauden oogst kan doen gelden. De normale pachttijd is het Mohammedaansche jaar; doch het staat partijen vrij een langeren termijn te bedingen, hetgeen doorgaans gepaard gaat met vooruitbetaling van de pacht, zoo niet voor alle, dan toch voor

1 Zelfs al staat dit plantsoen nog niet te velde. Soms wordt onderscheiden tusschen alib en kĕrab, in dien zin dat het eerste woord het plantsoen van den eersten moesson na het ontslag, en het laatste dat van den moesson van het ontslag aanduidt.

2 Gaat het apanage tusschen beide feesten op een ander over, zoo heeft deze aanspraak op den geheelen volgenden termijn.

3 In Djokjakarta is ook het verschijnen van den b ěkěl, bij dengeen van wien hij het perceel gepacht heeft, verplichtend op het feest $\mathrm{P}$ andjindrallan, d. w. $\mathrm{z}$. de verjaardag der Koningin, en op den Garěbĕg Bĕsar. 
vele jaren. De bẽk ĕl heeft dan zekerheid, dat niet na het eerste jaar het perceel aan een ander zal worden verpacht, en dat hij dus de voordeelen zal hebben van eventueele verbeteringen, door hem aan den grond aangebracht, bv. irrigatiewerken, nieuwe ontginningen, enz. Zulk een bĕkĕl, die zich voor meerdere jaren het genot van den grond verzekerd heeft, heet b ĕkĕl tĕbassan. Door de aldus gedane vooruitbetaling en vooraf toegezegde pachtverlenging is ook de opvolger in het apanage gebonden; alleen in geval van oneervol ontslag van den verhuurder uit zijne waardigheid, is de opvolger niet verplicht de overeenkomst na het loopende jaar voort te zetten, en behoudt de bĕk ĕl slechts eene persoonlijke vordering tot schadevergoeding tegen dengeen, met wien hij gekontrakteerd had. De b ĕk ĕl is verplicht het perceel, overeenkomstig de plaatselijke instellingen of de van overheidswege gegeven bevelen, als een goed huisvader te beheeren. Hij moet zich op het perceel vestigen, en mag zonder toestemming van den verhuurder geen tweede perceel pachten; maar wel mag hij elders gronden in onderpacht nemen. Geschillen, tusschentijds over de uitvoering van de overeenkomst tusschen den verhuurder en den b ěkĕl ontstaan, bv. over de grenzen van het perceel, dan wel over verhooging of verlaging van de pacht, ten gevolge van misgewas of veranderingen in den toestand van het terrein, moeten, alvorens in rechten te worden aanhangig gemaakt, worden onderworpen aan het oordeel van de b ĕkĕl's der vier, Oost, West, Zuid en Noord, naastbij gelegen perceelen en van de vier daarop volgende perceelen ${ }^{1}$. Elke bĕkĕl betaalt aan den verhuurder, afgescheiden van de jaarlijksche pacht, bij het aangaan van een nieuw contract een zeker geschenk in geld, b ěkti, d.i. "hulde", geheeten, hetwelk varieert naar de waarde van het perceel, den pachttermijn, enz. Gaat het perceel, gedurende den pachttijd, door overlijden van den bĕkĕl, op zijne erfgenamen over, zoo betalen dezen een extra-geschenk in geld, panganjar, d. i. "vernieuwing", genoemd 2. De bĕkĕl

1 De zoogenaamde montjo pat $(N)$ of m. sĕkawan (K) en m. limå (N) of $\mathrm{m}$. gangsal (K). Deze arbitrage van buren is reeds in het Hindoe-recht bekend. Zie Manoe, VIII: 258, 262 en vv.

2 Ook wel patoembas ing sěkar, d. w. z. "geld voor het koopen van bloemen", geheeten. Sommigen maken onderscheid, of de overgang op een zoon dan wel op eene dochter plaats heeft, en spreken alleen in het eerste geval van panganjar of patoembas ing sěkar, maar in het tweede van njåtrå b ěkti. Verdere erfgenamen hebben geene aanspraak op overgang van het contract, doch alleen een recht van naasting tegen den prijs, door een vreemde voor het perceel geboden. 
kan zijn contract niet aan een ander cedeeren, zonder toestemming van den verhuurder; maar tot de onderverhuur van gedeelten van het perceel is hij, ook zonder diens toestemming of zelfs voorkennis, bevoegd. De onderpachter heet bĕkĕl boeri (N) of b. wingking $(\mathrm{K})$ '.

\section{$\S$ 5. PAND.}

Het pandeontract heet in het Javaansch en Soendaasch: ga ḍ́, in laatstgenoemde taal ook: sanda, en in het Maleiseh: gadai of sanda. De vitdrukkingen voor "verpanden", "verpander" enz. zijn van deze wortels afgeleid. De inlandsche begrippen omtrent de hier te bespreken overeenkomst verschillen ten zeerste van de Moḥammedaansche. In den Islâm heeft zij een accessoir karakter, d. w. z. het pand strekt ter verzekering van de betaling eener schuld, en deelt het rechtslot der hoofdverbinteni s ${ }^{2}$. Naar inlandsche begrippen daarentegen is het eene zelfstandige overeenkomst, te vergelijken met het contrat pignoratif van het oude Fransche recht. De pandgever draagt het bezitrecht op het voorwerp over op den pandnemer; terwijl laatstgenoemde hem de overeengekomen geldsom geeft als contra-praestatie. De pandnemer wordt geen eigenaar, doch erlangt op het verpande voorwerp slechts een recht van gebruik of genot, onder verplichting bedoeld voorwerp aan

1 Vergl. Anggĕr Agĕng, art. 27; Anggĕr Sadåså, artt. 19-22, 28-35, 37, $38,44,52,55$; A. J. Spaan: Rapport omtrent de rechten die in de residentie Soerakarta op den grond worden uitgeoefend, als Bijl. B. gepubliceerd in dl. III van het Eindresumé, p. 16, 22 en vv., 35 en vv., 49 en vv.; Pranatan Patoeh of Djokjasche wet van 1863, houdende bepalingen omtrent de rechten en verplichtingen der prijaji's, die gronden in apanage hebben, als Bijl. C' gepubliceerd in hetzelfde deel van het Eindresumé, artt. 1, 4, 5, 6, 8-13; C. F. Winter: Instellingen, gewoonten en gebruiken der Javanen te Soerakarta, in het Tijdschrift voor Nederl. Indië, Jaarg. 1843, dl. II, p. 732 en vv.; Mr. P. Brooshooft: Solosche catechismus, opgenomen in het dagblad „De Locomotief”, Jaarg. 1889, p. 4-7 van den afzonderlijken afdruk; R. M. C. van Alphen: Landbezit in de Vorstenlanden, opgenomen in de Indische Gids, Jaarg. 1882, dl. II, p. 279 en vv.; Anonym: De landverhuur in Solo in korte trekken, opgenomen in het Tijdschr. v. h. Binnenl. Best., dl. I (1888), p. 383 en vv. Daar ik mij in het bovenstaande heb moeten beperken tot de behandeling der huurovereenkomst, d. w. $z$. het contract tusschen den běkěl en den verhuurder (vorst of geapanageerde), zoo wordt, voor de verhouding tusschen den běkěl en de op het perceel wonende bevolking, gelijk mede voor de agrarische toestanden, door het pachtsysteem in het leven geroepen, verwezen naar $\S 14$ van dit opstel.

2 Vergl. Fath al-Qarîb, p. 331. 
den pandgever te restitueeren, zoodra deze het inlost (Mal. Jav. Soend. těboes) door hem het opgenomen geld terug te betalen, tot welke betaling de pandgever, wanneer niet anders is bedongen, te allen tijde bevoegd blijft. De overeenkomst is dus, wat den pandgever betreft, van alternatieven aard: hij kan het voorwerp in handen van pandnemer laten, of hem het opgenomen geld teruggeven ${ }^{1}$.

Het behoeft geen betoog, dat deze overeenkomst wel een antichretisch karakter dragt, in zooverre dat de pandgever slechts de opgenomen som behoeft terug te geven, terwijl het gebruik of genot der zaak den pandnemer tot vergoeding voor het gemis van zijn kapitaal strekt; maar daarom is de overeenkomst nog geenszins met de Europeesche antichresis identiek. Bij laatstgenoemde overeenkomst immers heeft de schuldeischer eene vordering tot betaling; bij het inlandsche pandkontrakt niet. De antichresis is eene accessoire overeenkomst; het inlandsche pandeontract heeft een zelfstandig rechtsbestaan. Bij de antichresis is rente bedongen, waarvoor het gebruik of genot der zaak geheel of gedeeltelijk in de plaats treedt; bij het inlandsche pandeontract vervult het gebruik of genot ab initio de functie van rente ${ }^{2}$. Dit, met rentebeding onvereenigbare, antichretische pandrecht voor onbepaalden tijd vinden wij in de op Java gegolden hebbende Hindoerechtsbronnen terug, en de gevolgtrekking ligt dus voor de hand, dat wij ook hier weder met eene instelling van dat recht te doen hebben ${ }^{3}$.

Naast het pandrecht voor onbepaalden tijd, staat op Java en Madoera dat, waarbij een termijn (Mal. Jav. Soend. dja ndji)

1 Vergl. Verweij, t. a. p., p. 247 en vv. en de door dien schrijver aangehaalde plaats van Pothier (Oeuvres Complètes, dl. II, p. 1205). Volgens Dalloz, t. a. p., voce Nantissement, Nos 229 en 293 en vv. en de aldaar aangehaalde schrijvers, werd het contrat pignoratif wel veelal in den vorm van een gefingeerden verkoop met recht van wederinkoop gesloten, maar was het daarvan toch in aard onderscheiden, al ware tevens verhuur aan den verkooper bedongen. Het criterium lag in de vilité du prix, welke een element van het contrat pignoratif vormde. Was dit element niet aanwezig, zoo bestond er een wettige verkoop met recht van wederinkoop. Ook in dit opzicht is de overeenstemming met de Javaansche toestanden hoogst merkwaardig. Zie boven, p. 106, 107.

${ }^{2}$ Vergl. Verwey, t. a. p., p. 250; Code Civ., artt. 2085, 2089, en zie boven p. 107 noot 1.

3 Zie Manoe, VIII: 143, 145; Koeț. Mân., artt. 91, 114, in welke laatstgenoemde artikelen de buitengewone voordeelen, welke de zaak afwerpt, voor den pandgever worden gereserveerd. 
van aflossing der schuld door den crediteur is bedongen. Dit laatste pandrecht kan zoowel antichretisch zijn, als niet-antichretisch. Waar vee of andere roerende zaken in pand zijn gegeven, welke uit haren aard slechts een beperkten tijd bestaan, vinden wij zelfs in de oude en nieuwe Javaansche wetten bepaalde termijnen voor de inlossing vastgesteld, na verloop waarvan de crediteur gerechtigd is het pand, bij wanbetaling, te naasten (Mal. Jav. Soend. rampas), en niet, gelijk de Islâm voorschrijft, zich behoeft te bepalen tot het vorderen bij den rechter, dat het pand zal worden verkocht, om aan de opbrengst zijne pretensie te verhalen. Een dergelijk vervalleu van het pand aan den crediteur, bij wanbetaling, heeft evenzeer plaats bij een bedongen, als bij een door de wet of de gewoonte vastgestelden termijn, gelijk mede wanneer eene bepaalde rente in geld is bedongen, en die tot gelijke hoogte als het kapitaal is opgeloopen. Bij goederen, niet aan ondergang of waardevermindering onderhevig, en vooral bij vastigheden, is echter het beding van een termijn van inlossing zeldzaam ${ }^{1}$. Bij de bevoegdheid tot naasting moet intusschen rekening worden gehouden met de vraag of, wanneer het onroerend goed betreft, de pandnemer de zakelijke rechten van den pandgever vermag uit te oefenen. De beperkingen, ten gevolge van gemeentelijke instellingen, ten aanzien van het verkrijgen van grond bestaande, de onbevoegdheid van niet-inlanders om het erfelijk individueel gebruiksrecht op den grond uit te oefenen, en hunne nog niet door eene constante jurisprudentie uitgemaakte, maar m. i. toch bestaande onbevoegdheid tot uitoefening van het inlandsche erfpachtsrecht op de particuliere landerijen bewesten de rivier Tji Manoek zullen hierbij als factoren gelden ${ }^{2}$.

Voor verpanding zijn vatbaar roerende zoowel als onroerende goederen, waarvan men eigenaar is, of, bij onroerende goederen, het individueel erfelijk gebruiksrecht, dan wel het inlandsche erfpachtsrecht op de landerijen bewesten de rivier Tji Manoek heeft. Ook gebouwen of beplantingen afgescheiden van den grond zijn voor verpanding vatbaar, doch natuurlijk wederom niet vastigheden, waarop men zakelijke rechten volgens het Indische Burgerlijk Wetboek uitoefent, aangezien laatstgenoemde vastigheden slechts

I Vergl. Koeț. Mân., artt. 98, 99, 101, 120, 121; Anggĕr Sadåså, artt. 23, 25; Wilken, t. a. p., p. 601, 602; Eindresumé, dl. I, p. 51 en v., 200; Minhâdj aţTàlibîn, dl. I, p. 439, 442.

${ }^{2}$ Zie boven, p. 99 en vv. 
bij wege van hypotheek kunnen worden verbonden ${ }^{1}$. Aandeelen in communale velden kunnen niet worden verpand, en evenmin ambtsvelden in de Gouvernements-residentiën. Wel daarentegen kunnen in de Vorstenlanden de apanagehouders hun grond verpanden, ofschoon ook zij daarop slechts een tijdelijk en contractueel gebruiksrecht uitoefenen ${ }^{2}$.

Het pandrecht, hetzij voor onbepaalden, hetzij voor bepaalden tijd, hetzij antichretisch, hetzij niet antichretisch, is uit zijnen aard ondeelbaar. Nimmer kan de pandgever den pandnemer dwingen de zaak terug te geven vóór de algeheele voldoening der schuld. Zonder beding van het tegendeel zijn de verbeteringen, door den pandnemer aan de zaak aangebracht, ten voordeele van den pandgever, wanneer hij het pand inlost. Elk pandrecht gaat verder over op of tegen de erfgenamen of rechtverkrijgenden, respektievelijk van pandgever of pandnemer. De laatste is echter niet bevoegd de zaak in achterpand te geven, of zijne pretensie aan een ander te cedeeren, tenzij met toestemming van den debiteur ${ }^{3}$. Niet zelden worden hieromtrent bij het aangaan der overeenkomst de noodige bedingen gemaakt. Verhuur aan den pandgever heeft plaats geheel onder dezelfde voorwaarden als ingeval van verkoop met recht van wederinkoop; terwijl ook de daarbij aangegeven beperkingen van het recht tot inlossing op een ongelegen tijd, speciaal wat bouwgronden betreft, bij het pandrecht gelden ${ }^{4}$. Ondergang of verlies van het pand makt de schuld dadelijk opvorderbaar, tenzij aan den pandhouder te wijten 5. Eindelijk

1 Zie boven p. 86, en vergl. artt. 1150 en 1162 Ind. Burgerl. Wb. $=$ artt. 1196 en 1208 Ned. B. W.

2 Zie boven, p. 101, en vergl. Eindresumé, dl. I, p. 18, 116, 143, 185, 189, $200,214,216,221$. Bij erven in erfelijk individueel bezit schijnt het verpanden ongebruikelijk, en de verkoop met recht van wederinkoop daarvoor altijd in de plaats te treden. Ibid. p. 166. Voor het verpanden van apanagegronden in de Vorstenlanden, vergl. Anggěr Sadåså, artt. 20,21. De contractueele gebruiksrechten der bevolking op den grond in de Vorstenlanden en elders zijn wederom niet voor verpanding vatbaar.

3 Bij verkoop met recht van wederinkoop heeft de kooper de bevoegdheid tot vervreemden van rechtswege. Zie boven p. 106. Het geven in achterpand of het cedeeren der pretensie heet in het Javaansch: ělih, en in het Soendaasch en Maleisch: pindah, met bijvoeging respectievelijk van ga ̣é, sanḍa of gadai.

4 Zie boven, p. $105,106$.

$5 \mathrm{Bij}$ verkoop met recht van wederinkoop, zoude ondergang of verlies, met of zonder schuld van den kooper, uitsluitend dezen laatsten treffen, als zijnde hij eigenaar geworden. 
komt het, wat den vorm betreft, bij alle soorten van pandovereenkomsten voor, dat de pandnemer aan den pandgever althans een onderhandsch bewijs geeft, dat hij het goed in pand heeft ontvangen. Geldt het vaste goederen, dan wel roerende goederen van groote waarde, zoo is naar de omstandigheden, verklaring van getuigen, ja zelfs tusschenkomst van het dorpsbestuur, of het opmaken van een notarieel contract in zwang, ofschoon, vooral buiten de hoofdplaatsen en groote centra van bevolking, partijen zich ook alsdan niet zelden met de algemeene bekendheid tevreden stellen, zoo zij zich al niet geheel op elkanders goede trouw verlaten ${ }^{1}$.

Als eigenaardigheden van het antichretische pandrecht moet nog het volgende vermeld worden. Een enkele maal strekken, volgens overeenkomst, wel eens de vruchten, welke de zaak afwerpt, voor een gedeelte tot aflossing der schuld; zoodat de pandgever na zekeren tijd zijn goed, zonder eenige betaling zijnerzijds terugbekomt ${ }^{2}$. Aan den anderen kant wordt dikwijls, de antichretische pandovereenkomst, na eenigen tijd te hebben geloopen, door partijen geconverteerd in een verkoop met recht van wederinkoop, indien de primitief opgenomen som, welke veelal ver beneden de waarde der zaak was, door nieuwe geldopnemingen tot een bedrag is verhoogd, dat ten naastenbij aan de waarde der zaak gelijk is geworden. Dit laatste, en het geval dat de schuld met de achterstallige renten tot zoodanig bedrag is opgeloopen, zijn ook dikwijls oorzaak der conversie van een niet-antichretisch pandrecht in een verkoop met recht van wederinkoop ${ }^{3}$.

De hier beschreven inlandsche begrippen omtrent het pandrecht hebben natuurlijk geene betrekking op de hypotheek, door een inlander genomen op een vast goed, beheerscht door het Indische Burgerlijk Wetboek, noch op bodemerij, door hem gesloten met inachtname van artt. 569 en vv. Ind. Wb. van Koophandel, noch eindelijk op het oogstverband, geregeld bij Ind. Stbl $1886 \mathrm{n}^{\circ} 57$.

1 Vergl. Eindresumé, dl. I, p. 51-54, 127; Anggĕr Sadåsa, art. 26. Het eerste lid van dit artikel is niet duidelijk. Men zoude er uit kunnen opmaken, dat de pandhouder, van zijn kant, den pandgever, in geval van toevallig verlies moest schadeloos stellen; doch, zoo dit de juiste opvatting is, geldt het voorschrift stellig niet buiten de Vorstenlanden.

${ }^{2}$ De overeenkomst draagt alsdan het karakter van den vif-ga ge van het oude Fransche recht, in tegenoverstelling van haar gewoon karakter van mort-gage. Vergl. Dalloz, voce Nantissement, No 22.

3 Zie boven, p. 106, 107, en vergl. Eindresumé, dl. I, p 53, 127. 


\section{$\S 6$. Verbruikleen.}

Het schuldrecht, naar de inlandsche begrippen, is geheel afwijkend van de beginselen van den Islâm. Geen recht kan men zeggen, dat voor den debiteur gunstiger is dan het Moḥammedaansche. Naar een vitdrukkelijk voorschrift van den Koran ${ }^{1}$ moet een debiteur, die werkelijk niet betalen kan, zonder dat hij zelf zijn onvermogen met opzet heeft veroorzaakt om zijne crediteuren te bedriegen, en zonder dat hij de schuld ontkent, met rust worden gelaten. Bovendien bestaat voor iemand de verplichting tot betaling zijner schulden, alleen onder de voorwaarde dat hij daartoe in staat is, zonder in zijne verplichtingen jegens Allâh, jegens zich zelven en jegens de personen, die hij onderhouden moet, te kort te schieten ${ }^{2}$. Het renteverbod van den Koran is absoluut, en betreft niet slechts geldleeningen, maar ook het leenen van levensmiddelen ${ }^{3}$. $\mathrm{Nu}$ zijn, wel is waar, gelijk wij straks zien zullen, de voorschriften der juristen, omtrent het renteverbod, juist door hunne specialiteit, in onze dagen gemakkelijk te ontduiken; maar dit neemt niet weg, dat het beginsel, waarvan die voorschriften uitgaan, van eene merkwaardige mildheid tegenover de verbonden partij getuigt.

Daarentegen is het Javaansche schuldrecht van ouds zeer streng. Ik heb hier niet zoo zeer het oog op het, reeds in het wetboek Soerjå Ngalam afgeschafte, recht van den crediteur om zich eigenmachtig eenig goed van den debiteur toe te eigenen (Mal. Jav. Soend. rampas ${ }^{4}$ ), welk recht ook in de latere Javaansche wetten aan den crediteur wordt ontzegd, doch in het Hindoe-tijdvak op Java bestond ${ }^{5}$. Deze bevoegdheid immers kent ook de Islâm, ondanks zijn bijzonder zacht schuldrecht ${ }^{6}$.

1 Koran, II: 280.

2 Zie Minhâdj aț-Ṭalibîn, dl. II, p. 1, 6 en vv., dl. III, p. 425. Bij de beoordeeling van de eerlijkheid van een vroom Muzelman, mag men dit, van het onze verschillende, standpunt nooit uit het oog verliezen. Zijne begrippen omtrent de zedelijke verplichting, om zijne handteekening te honoreeren, zijn anders dan de onzen.

3 Vergl. Koran, II: 276-278, III: 125 , IV : 159 , en den Commentaar van Baidhâwî op deze plaatsen.

4 In het Javaansch ook tjanḍak tjěkěl of djarah rajah genoemd.

5 Vergl. Koeţ. Mân., art. 84; Soerjå Ngalam, t. a. p., p. "43; Papakĕm van Cheribon, in het Tijdschrift: Het Recht in N. I., dl. III (1850), p. 220; Nawålå Pradåtå, art. 14; Anggĕr Agĕng, art. 6; Wilken, t. a. p., p. 559 en vv.

6 Vergl. Minhâdj aț-Tâlibîn, dl. III, p. 425 en vv. 
Wat het nationale Javaansche schuldrecht van het Mohammedaansche vooral onderscheidt, is dat, bij wanbetaling, wanneer de pretensie niet op de goederen van den debiteur kan worden verhaald, deze daarvoor pandeling (Jav. moedjangan, Soend. boedjang, Mal. orang bĕroetang) wordt; voorts het rentebeding als eene, in beginsel niet slechts geoorloofde, maar zelf in de natuur der overeenkomst liggende zaak, en eindelijk de bevoegdheid om den debiteur tot de uiterste armoede te brengen.

Het pandelingschap is stellig van Polynesischen oorsprong. Het Hindoe-recht kent, ook blijkens de op Java gegolden hebbende wetten, de schuldslavernij, maar niet het recht van pand op een insolventen debiteur, en nog veel minder het recht van pandbeslag op zoodanigen debiteur en op de leden van zijn gezin ${ }^{1}$. Dit pandbeslag op een vrij persoon en op zijn gezin, is wel te onderscheiden van het contractueele pandelingschap, $\mathrm{d}$ w. z. de overeenkomst, waarbij men zich zelf in antichretisch pand geeft bij het opnemen van geld, eveuals een ander eene hem toebehoorende zaak aldus verbindt. Dit laatste wordt, of liever werd, ook op Java door de gewone regelen van het antichretische pandcontract beheerscht. Beide soorten van pandelingschap waren sedert vele eeuwen op Java en Madoera in zwang, en worden nog in de Javaansche wetten der Vorstenlanden erkend ${ }^{2}$. Intusschen was, ook bij het pandbeslag op menschen, van ouds de eigenrichting uitgesloten ${ }^{3}$. De treurige gevolgen van het pande-

1. Vergl. Manoe, VIII: 177, 415, 416; Koeț. Mân., artt. 270, 217. Daarentegen schijnen artt. 80 en 161 Ibid. niet op schuldslavernij, maar op pandelingschap te doelen. Is deze opvatting juist, dan hebben wij in dit artikel wederom te doen met eene specifiek Javaansche afwijking van het dogmatische. Hindoe-recht. Over het praktische en juridische verschil tusschen pandelingschap en schuldslavernij, zie Verwey, t. a. p., p. 237, 238, 240. Daar het pandelingschap op Java en Madoera thans tot het verleden behoort, meen ik, ten aanzien van dit onderwerp, met eene eenvoudige verwijzing naar dit voortreffelijke opstel te mogen volstaan.

2 Vergl. Verwey, t. a. p., p. 534 en vv.; Wilken, t. a. p., p. 565 en 574 ; Soerjå Ngalam, p. 22; Naw. Prad., artt. 9 en 10; Angg. Ag., art. 2; Angg. Sad., artt. 3, 12,50 . Volgens den Islâm is een vrij persoon buiten den handel, en dus noch voor eigendom, noch voor eenig ander zakelijk recht vatbaar. Tusschen echtgenooten bestaat absolute scheiding van vermogen, en kinderen zijn nooit verplicht de schulden hunner ouders te voldoen, voor zooverre deze de baten van den, door laatstgenoemden nagelaten, boedel te boven gaan. De rechter kan in zekere gevallen den debiteur dwingen voor zijn crediteur te werken; doch dit laat den persoonlijken staat van den debiteur onaangetast. Zie Minhâdj aț-Tâlibîn, dl. II, p. 8,223 , dl. III, p. 90 en vv., 229.

3. Vergl. Koeţ Mân., artt. 85 en 108; Angg. Ag., art. 6. In het opstel van wijlen Wilken (t. a. p., p. 565) wordt daarentegen geen onderscheid gemaakt tusschen het verbod van de eigenrichting als executie-middel, en het verbod van het pandbeslag zelf. 
lingschap, uit een economisch oogpunt, mogen als bekend worden ondersteld ${ }^{1}$, en de Oost-Indische Compagnie had dan ook reeds, bij plakkaat van 24 Augustus 1696, het contractueele pandelingschap in haar gebied verboden, omdat allerlei "ongemacken" daaruit voortvloeiden, welk verbod, bij plakkaat van 8 November 1715 werd herhaald, en ook tot het pandbeslag bij wanbetaling werd uitgebreid ${ }^{2}$. In de Vorstenlanden bleef intusschen het pandelingschap met beide functiën nog bestaan tot $1822^{3}$.

Het rentebeding, zelfs tot een bedrag, dat in Europa voor buitensporig zou worden gehouden, is eveneens op Java en Madoera gewoon ${ }^{4}$, en wortelt blijkbaar wederom in het Hindoe-recht ${ }^{5}$. Trouwens het Moḥammedaansche recht verbiedt wel goud, zilver of levensmiddelen te geven, met het doel om grootere hoeveelheden daarvan terug te bekomen, bv. 100 guldens om over eene maand met 110 guldens terug te betalen; maar het verbod heeft geene betrekking op terugbetalingen in een ander metaal of in eene andere soort van levensmiddelen, noch a fortiori op het geval dat de rente of het kapitaal in den vorm van bankbiljetten wordt betaald ${ }^{6}$. De economische toestanden, in de Middeleeuwen in Zuid-Westelijk Azië bestaande, welke toestanden de klassieke Arabische juristen voor oogen hadden, wier werken thans nog als wet gelden, wijken zoozeer af van die in onzen tijd, dat niettegenstaande het door hen tot in de verste consequentiën en in allerlei bijzonderheden uitgewerkte renteverbod, de geloovigen tegenwoordig nergens meer, zelfs in hunne meest exorbitante woekertransactiën, beperkt zijn. Alleen de moreele band van den godsdienst blijft, en Arabieren, hadji's, en andere als kerksch bekend staande personen, geven dan ook de voorkeur aan het maskeeren van hun woeker door andere contracten.

1 Vergl. Veth: Java, dl. I, p. 520, 526.

2 Vergl. Plakaatboek, dl. III, p. 410, en dl. IV, p. 73.

8 Ind. Stbl. 1822 No 10.

4 Vergl. o. a. bovenaangehaald plakkaat van 8 November 1715 , en, voor de tegenwoordige toestanden, C. Poensen:-Naar en op de pas a r, in de Meded. $v$. h. Nederl. Zend. Gen., dl. XXVI (1882), p. 21 ; Fokkens, t. a. p., p. 34 en vv. en 44; Wilken, t. a. p., p. 604. Zie ook Angg. Sad., artt. 23, 25, en het vonnis van den Landraad te Probolinggo van 16 Januari 1894 (Ind. Weekbl. v. h. R., No 1624).

• Vergl. Manoe, VIII: 140 en vv.; Koeț. Mân., artt. 72-75, 80, 82, 104, 262-266.

- Vergl. Minhâdj aṭ-Tâlibîn, dl. I, p. 355 en vv. en 425 en vv.; Fath al-Qarîb, p. 315 . 
De inheemsche bevolking op Java en Madoera is, om economische oorzaken welke niet tot ons onderwerp behooren, en bovendien reeds voldoende door anderen zijn uiteengezet ${ }^{1}$, veelal in de voortdurende noodzakelijkheid van geld of andere vervangbare zaken, bv. zaadpadi, te leenen bij Europeanen, Vreemde Oosterlingen, of enkele meer vermogende landgenooten. Zelfs zij, die zich onder gewone omstandigheden buiten schuld weten te houden, vervallen op betrekkelijk weinige vitzonderingen na, daarin bij den minsten tegenspoed, als misgewas, enz. Bezit de Javaan nu geene roerende goederen van voldoende waarde, om daarmede zich in de officieel erkende pandhuizen geld te verschaffen, dan wel ziet hij tegen de daaraan verbonden formaliteiten op, zoo valt hij in handen van particulieren, die in den regel de transactie omgieten in eene der reeds in den loop van dit opstel vermelde overeenkomsten van verkoop met recht van wederinkoop, verhuur met vooruitbetaling van den huurprijs of het loon, en de straks te bespreken overeenkomsten van voorschot op den oogst of van maatschap ${ }^{2}$. De oorzaak hiervan

1 Vergl. o. a. Sollewijn Gelpke: Naar aanleiding van Staatsblad 1878 No 110 , passim; Arminius: Het budget van een Javaanschen landbouwer, in de Ind. Gids, Jaarg. 1889 , p. 1685 en vv., 1885 en vv. en 2149 en vv.; Poensen, t. a. p., p. 21, 24; Dezelfde: Iets over de Javaansche desa, in de Meded. v. h. Ned. Zend. Gen., dl. XXXVII (1893), p. 344 en vv.; Fokkens, t. a. p., p. 33.

2 Als eene merkwaardige combinatie van inlandsche en Europeesche overeenkomsten, welke te zamen niets dan eene credietverleening beoogen, kan men beschouwen het volgende contract, sedert lang door vele suikerfabriekanten met inlanders ten behoeve van het riettransport gesloten. Het gebruikelijke voorschot op het transportloon wordt in de acte vermeld als prijs voor de kar en het span trekdieren, waarmede het transport moet geschieden, en welke de eigenaar verklaart te hebben verkocht aan den fabrikant, met recht van wederinkoop na afloop der suikercampagne, doch onder voorwaarde dat deze zaken hem door den kooper tot dien termijn in bruikleen zullen worden afgestaan. Het loon voor de verrichte iransportdiensten wordt slechts voor één dag van de 5 of van de 7 dagen uitgekeerd; dat voor de overige dagen wordt ingehouden, en strekt tot payementen van de betaling van den wederinkoopprijs, zoodanig dat, na afloop der campagne, de Inlander kar en beesten zal hebben terugbetaald. Op wanpraestatie is eene geldelijke poenaliteit gesteld, welke van het verdiende loon wordt afgehouden. Is de wederinkoopprijs, met de poenaliteit, bij het einde der campagne niet aldus kunnen verrekend worden, zoo heeft de fabrikant het recht kar en beesten te naasten, dan wel het gebruik daarvan aan den inlander te laten, tegen overschrijving van de schuld op de rekening van de volgende campagne. Soms is zelfs bedongen, dat de fabrikant het naastingsrecht van kar en beesten heeft, in bepaalde gevallen van grove wanpraestatie gedurende de campagne; doch daartegenover staat in vele contracten, dat de fabrikant belooft, bij het einde der campagne, boven het transportloon, eene in verhouding hooge 
is, dat de geldschieter zich aldus eene reeële zekerheid verschaft, zonder tot pand of hypotheek zijne toevlucht te nemen, en gemakkelijker zijn debiteur in den waan kan brengen, dat de voorwaarden voor hem weinig onereus zijn, althans minder dan inderdaad het geval is. Welke van de hier bedoelde schijnovereenkomsten wordt aangegam, hangt af van de persoonlijke omstandigheden, waarin partijen verkeeren, van gemoedsbezwaren aan den Moḥammedaanschen godsdienst ontleend, enz. Dat alle pogingen om in dezen toestand verbetering te brengen, zijn mislukt, is wel een bewijs, dat men hier met een treurig, maar niettemin natuurlijk verschijnsel te doen heeft ${ }^{1}$.

Wanneer eene niet-vermomde overeenkomst van verbruikleen wordt gesloten, geschiedt dit in den regel vergezeld van pandrecht, en, indien er meerdere debiteuren zijn, van solidaire aansprakelijkheid (Mal. tanggoeng mĕnanggoeng, Jav. Soend. tangg o eng rèntèng). De hierboven bedoelde kerksche Muzelmannen trachten intusschen ook dan het rentebeding te vermijden, door bv. in naam eene hoogere som te leenen dan feitelijk wordt ontvangen, of door eene poenaliteit te stellen op de niet-betaling op den overeengekomen termijn, welke betaling, of welke termijn, dan zoo wordt voorschreven, dat de debiteur daaraan, ook in verband met de zorgeloosheid aan inlanders eigen, naar alle waarschijnlijkheid niet zal voldoen. Schuldbekentenissen voor groote sommen worden tegenwoordig hoe langer hoe meer notarieel сpgemaakt. Voor kleinere bedragen is het afgeven van een onderhandsch schuldbewijs regel, zelfs op het platte land. Kunnen partijen niet schrijven, zoo helpt hen een goed vriend of de dorpsschrijver; terwijl men ook dikwijls getuigen bij de handeling neemt, die het stuk met den debiteur onderteekenen, desnoods met een kruisje. Van eene officieele bemoeienis van het dorps- of districtsbestuur, gelijk wij die bij de verkoopbewijzen hebben ontmoet, is echter bij het opmaken van de hierbedoelde schuldbekentenissen geen sprake ${ }^{2}$. In de Vorstenlanden is den crediteur zelfs de actie wegens verbruikleen ontzegd, wanneer hij geene

premie te betalen, wanneer de karrevoerder zonder interruptie aan alle zijne verplichtingen zal hebben voldaan. Ik dank deze mededeeling aan den heer $\mathrm{H}$. E. Steinmetz, laatstelijk assistent-resident van Bondowoso.

1 Een aardig voorbeeld van recenten aard tot illustratie van het hier medegedeelde, is te lezen bij Fokkens, t. a. p., p. 37, met opzicht tot het Indische Staatsblad van 1891 No 10 .

2 Zie boven, p. $97,98$. 
duidelijk geschreven en gave schuldbekentenis kan overleggen. Tusschenvoeging of doorhaling zijnerzijds in het document is als valschheid strafbaar. Teruggave van de schuldbekentenis is het eenige wettige bewijsmiddel van de betaling; zoolang die teruggave niet heeft plaats gehad, kan de debiteur desnoods op nieuw tot betaling der schuld in rechten worden aangesproken ${ }^{1}$.

Over de bijzondere voorschriften en instellingen omtrent de wijze, waarop de concursus creditorum plaats heeft, is reeds elders gehandeld ${ }^{2}$. Daarentegen worden wederom de voorschriften van het Mohammedaansche recht ten aanzien van de vraag, of schulden preferent dan wel concurrent zijn, bij de liquidatie opgevolgd, voor zooverre die opvolging niet wegens verschil van toestanden onmogelijk is, bv. de preferentie van den bloedprijs en van de djakat (Arab. zakâh) ${ }^{3}$. Bij de executie op onroerend goed zal steeds rekening moeten worden gehouden met den aard van het recht, door den inlander op den grond uitgeoefend; en met de beperkingen ten aanzien van het verkrijgen daarvan door wettelijke bepalingen of door gemeentelijke regelingen. Zoo zal beslag op aandeelen in de communale velden onmogelijk zijn, eu zullen personen, die de bevoegdheid missen om in het dorp als grondbezitter op te treden, ook zijn uitgesloten van het koopen van grond bij gelegenheid van een executorialen verkoop ${ }^{4}$.

Een zeer gewoon middel om buiten tusschenkomst des rechters betaling van eene pretensie te erlangen, is het, aan het Hindoerecht ontleende, voortdurend manen van, of liever de wacht houden bij den debiteur. De overlast van de tegenwoordigheid des crediteurs, door den debiteur ondervonden, en, vooral indien het een Arabier of als vroom bekend persoon geldt, de bijgeloovige vrees, dat den crediteur aldus iets zal overkomen, tengevolge van het niet voldoen der wettige pretensie, doen doorgaans betaling volgen ${ }^{5}$.

\section{§7. ANDERE OVEREENKomsten.}

Ruil heet in het Javaansch: liroe (N) of lintoe (K), in het

1 Vergl. Naw. Prad., art. 19; Angg. Sad., art. 58. Blijkbaar wortelen deze voorschriften in het Hindoe-recht. Vergl. Koeț. Mân., artt. 81, 83, 84, 106, 109, 110.

2 Vergl. Familie- en erfrecht, p. 500.

3 Vergl. Minhâdj aț-Tâlibîn, dl. II, p. 223, en het Maleische werkje van Sajjid 'Othmân bin 'Abd Allâh bin Jahjâ, getiteld: Kitab 'ilmoe paraïl, p. 4.

4 Vergl. boven, p. 99 en vv.

5 Vergl. Maine, t. a. p., p. 40 en 297-304; Manoe, VIII: 49; Wilken, t. a. p., p. 567. 6e Vogr. III. 
Soendaasch : to eke ur, en in het Maleisch : to e kar. Deze overeenkomst heeft op Java en Madoera eene veel grootere economische beteekenis dan bv. in Nederland. In de binnenlanden vindt men zelfs pasar's, waar bijna alle zaken bij wege van ruilhandel gedreven worden ${ }^{1}$, en in de afgelegen dorpen is dit a fortiori het geval. Gebrek aan circuleerend medium is hiervan natuurlijk de oorzaak. Zoowel roerende als onroerende zaken, ja zelfs rechten ${ }^{2}$, worden onderling en wederkeerig tegen elkander geruild, wat de onroerende zaken betreft, ook in geval men daarop slechts eene contractueele anspraak heeft. Zoo komt tusschen aandeelhouders in de communale velden dikwijls ruil hunner aandeelen vonr ${ }^{3}$. Eene bijzondere soort van ruil is het wisselen van geld, en wel wederom in een zeer eigenaardigen vorm. Het bedrijf van den wisselaar (Mal. Jav. Soend. toekang réjal) bestaat namelijk daarin, dat hij bankpapier of standpenningen inwisselt tegen pasmunt of kopergeld, tegen een zeker agio, soms tot 5 pCt. en zelfs tot 10 pCt., niet, gelijk men zoude onderstellen, op de pasmunt of het koper, maar op het bankbiljet of de standpenningen. Het wisselen van pasmunt of koper tegen standpenningen of bankbiljetten geschiedt doorgaans, zoo niet gratis, dan toch tegen eene aanmerkelijk lagere belooning. De oorzaak van dit schijnbaar abnormale verschijnsel is te zoeken in de omstandigheid, dat de groote meerderheid der inlanders, tengevolge van de geringe bedragen, welke zij voor hunne dagelijksche inkoopen besteden, veelal meer behoefte hebben aan kleingeld dan aan guldens of rijksdaalders, om van bankpapier niet te spreken; terwijl zij bovendien, buiten de groote handelsplaatsen, van de zekerheid, welke laatstgenoemd betaalmiddel aanbiedt, over het geheel weinig begrip hebben.

Voorschot op den oogst (Mal. tĕmpah, Jav. idjon (N) of idjĕmman (K), Soend. ti mpah) is het s a la m-contract der Arabische juristen 4, maar beperkt tot landbouw-producten, terwijl de voorschriften van bedoelde juristen, om te waken dat de debiteur vooraf goed wete, waartoe hij zich verbindt, voor niet geschreven worden gehouden. Van ouds is het dan ook eenvoudig eene soort van woekerovereenkomst, en is de debiteur tot praestatie gehouden

1 Vergl. Sollewijn Gelpke: Gegevens, enz., p. 592.

2 Vergl. Eindresumé, dl. I, p. 199.

s Ibid. p. 74.

4 Vergl. Minhâdj aṭ-Tâlibîn, dl. I, p. 414 en vv. 
onafhankelijk van het slagen van den oogst ${ }^{1}$. De vorm, waarin het contract zich vroeger het meest voordeed, namelijk het betalen door den geldschieter van de landrente, door eene geheele inlandsche gemeente verschuldigd, tegen afstand van het te velde staand rijstgewas, is verboden bij $\S 4$ van Ind. Stbl. 1834 No 52 ; maar dit verbod heeft geene betrekking op dergelijke overeenkomsten, individueel gesloten. Eene analoge overeenkomst is het geven van voorschot, zoodanig dat bij mislukking van den oogst de geldschieter zijne aanspraak verliest, en hij bovendien de helft van de kosten van bearbeiding en van de landrente draagt. Deze afwijking van het salam-contract schijnt intusschen alleen in Bantam voor te komen, en heet daar djampäng ${ }^{2}$.

Maatschap heet in het Javaansch: baṭon, sakoetoe of sirkat, in het Soendaasch: sarikat, en in het Maleisch: pĕrséroan of pĕrsĕk oet o ean. In strijd met de Moḥammedaansche wet ${ }^{3}$ worden maatschappen aangegaan, niet slechts tusschen personen, die elk een zeker kapitaal in geld, of althans in op geld gewaardeerde goederen inbrengen, maar ook tusschen hen, die niets dan hun arbeid gemeen maken, bv. tusschen sjouwers. Bij dergelijke, steeds mondeling aangegane associaties, kiezen de deelhebbers zich een mandoer of hoofd, die met den werkgever contracteert, en veelal het loon voor allen ontvangt ter latere verdeeling. Ja zelfs, als het loon om de eene of andere reden heet individueel te worden uitbetaald, wordt het, na ontvangst, niet zelden weder bijeengevoegd, om, overeenkomstig de onderling vooraf gemaakte afspraken, opnieuw en op andere wijze te worden verdeeld. Ook de Moḥammedaansche commanditaire vennootschap komt veel voor; doch wordt in de inlandsche talen niet door een anderen naam dan de gewone maatschap aangeduid. Zij is verder in gebruik, niet slechts, gelijk de Islâm vordert ${ }^{4}$, voor het drijven van handel, maar ook voor allerlei soorten van nijverheid. Zij ontaardt in beide gevallen niet zelden in een vermomd woekercontract, vooral wanneer het door den geldschieter gefourneerde kapitaal niet in geld, maar in levensmiddelen of andere goederen bestaat, en daarvoor eene vaste rente is bedongen, iets dat de Islâm wederom ver-

1 Eindresumé, dl. II, Bijlagen, p. 160; Resumé van Bantam, p. 122, 123.

2 Vergl. Resumé van Bantam, p. 123.

3 Minhâdj aṭ-Ṭâlibîn, dl. II, p. 49, 50.

4 Ibid. p. 133. 
biedt ${ }^{1}$. De gereerende vennoot ontvangt dan van den geldschieter veelal slechts onderhoud, en moet hem daarvoor op afbetaling alles afstaan, wat hij met het kapitaal verdient of verkrijgt, bv. als hij visscher is, en de geldschieter heeft hem een vaartuig of netten verschaft dan wel de middelen om die aan te koopen, alle door hem te vangen visch, welke dan weder door den geldschieter in den regel te laag wordt getaxeerd; terwijl het levensonderhoud, voor zooverre het in natura is verstrekt, te hoog wordt aangerekend. Zelfs is het beding, dat de geheele winst voor den geldschieter zal zijn, tegen verstrekking van levensonderhoud aan den gereerenden vennoot, niet ongebruikelijk. Bij den minsten tegenspoed, moet de man zijne instrumenten verkoopen, dan wel opnieuw geld leenen, en zoo geraakt hij op den duur onherroepelijk in de macht van zijn erediteur ${ }^{2}$. Eene speciale soort van commanditaire maatschap, welke niet het karakter van een woekercontract draagt, is die, welke gewoonlijk door herders wordt aangegaan. De herder ontvangt bij deze maatschap van den veebezitter één of meer beesten, welke hij voor zijne rekening moet oppassen en onderhouden. Als belooning heeft hij dan aanspraak op een zeker deel, veelal $\frac{1}{2}$ of $\frac{1}{3}$ van de jongen, uit het beest of uit de kudde geboren; terwijl daarentegen de andere voordeelen van het beest of van de kudde in hun geheel toebehooren aan den eigenaar ${ }^{3}$.

Bij lastgeving is de eenige belangrijke afwijking van de Mohammedaansche beginselen, dat de lasthebber (Mal. Jav. Soend. wakil, v. h. Arab. wakîl), bij gebreke van een tegenstrijdig beding, aanspraak heeft op loon. Is in de overeenkomst geen loon bepaald, zoo moet, bij verschil, de rechter het begrooten ${ }^{4}$. In de Vorstenlanden geldt nog de regel, dat het afstaan aan iemand van

1 Ibid. p. 132, 134, 135 .

2 Vergl. Van Gennep, t. a. p., p. 95; Fokkens, t. a. p., p. 34, 37. Een merkwaardig voorbeeld van een zoodanig associatie-contract, wel is waar van Makassar af komstig, vindt men in het Tijdschrift: Wet en Adat, Afd. Kleinere Bijdragen, Jaarg. 1896 , p. 48 en vv.

s Ook deze mededeeling dank ik aan den heer H. E. Steinmetz. Om dit contract uit een economisch oogpunt juist te beoordeelen, moet men in het oog houden, dat in den regel de herder het vee op onbebouwden grond kan laten weiden, dan wel aldaar gras kan snijden, zonder vergoeding. Voor het voedsel van het vee behoeft hij dus geen geld uit te geven.

4 Vergl. Minhâdj aț-Tâlibîn, dl. II, p. 65, 71; vonnis van den Raad van Justitie te Batavia dd. 25 Febr. 1867 (Ind. Weekbl. v. h. R., No 191); arrest van het Hoog Gerechtshof dd. 8 Sept. 1867 (Tijdschr. Het R. in N. I., dl. XLIX (1887), p. 316 en vv.). 
zijn zegel, jegens derden, als algemeene lastgeving geldt, zoodat de lastgever gebonden is door de daden van zijn aldus geconstitueerden lasthebber, al had hij hem in zijn mandaat beperkt, behoudens natuurlijk zijn verhaal op den ontrouwen mandataris '.

De speciale voorschriften, in de Vorstenlanden bestaande omtrent borgtocht (Jav. ta nggoeng (N) of tangg ĕl (K), Soend. Mal. tanggoeng) door ambtenaren voor hunne ondergeschikten ${ }^{2}$, missen in het overige gedeelte van Java en op Madoera, wegens het verschil in toestanden, alle toepasselijkheid; terwijl eindelijk de schenking van een belangrijk deel van het vermogen alleen voorkomt bij wege van uiterste wilsbeschikking, en daarom bij het erfrecht is behandeld ${ }^{3}$.

\section{§ 8. ALGEMEENE BESCHOUWINGEN OVER DE RECHTEN OP ZAKEN.}

Wanneer men de agrarische toestanden uitzondert, kan men zeggen, dat over het algemeen op Java en Madoera de begrippen der inheemsche bevolking geene belangrijke afwijkingen opleveren van de Mohammedaansche beginselen omtrent zakelijke rechten.

De verjaring, als middel om zakelijke rechten te verkrijgen, is onbekend ${ }^{4}$. Evenzoo de regel, dat bij roerende zaken bezit als titel geldt ${ }^{5}$. Gebouwen en beplantingen zijn voor het uitoefenen van zakelijke rechten vatbaar, afgescheiden van den grond, waarop zij staan; terwijl het bezit op zich zelf nimmer als een recht wordt aangemerkt. Wel is waar wordt hij, die animo domini en te

1 Vergl. Angg. Sad., art. 54.

2 Zie Angg. Sad., artt. 1-4. In den Soerjå Ngalam (p. 46) vinden wij nog den rechtsregel, dat het wegloopen van den debiteur met diens insolventie gelijk staat, en dat de borg dan moet betalen. Vergl. mijne Rechtsbronnen van Zuid-Sumatra, p. 300 , en Het handels- en scheepswetboek der Wadjoreezen (editie van Dr. B. F. Matthes), p. 60. Ik kan nergens vermeld vinden, of die rechtsregel ook thans nog op Java en Madoera gehuldigd wordt. Vermoedelijk is dit echter het geval.

3 Vergl. Familie- en erfrecht, p. 509 en vv.

4 Herhaaldelijk werd aldus door den rechter beslist. Zie o. a. een vonnis van den Landraad te Tjiringin dd. 14 Aug. 1872 (Ind, Weekbl. v. h. Recht, No 489), en een vonnis van den Landraad te Modjokerto dd. 12 Maart 1879 (Ibid. No 847).

5 Vergl. Nawålå Pradåtå, artt. 22, 25 en 26. In laatstgenoemd artikel wordt de termijn van één jaar, welken de Islâm stelt voor de voorloopige toeëigening van gevonden goed, tot 3 maanden verkort. Vergl. Minhâdj aṭ-Tâlibîn, dl. II, p. 205. Art. 12 van den Anggĕr Agĕng sluit de revindicatie van roerend goed tegenover den derden verkrijger uit, wanneer deze te goeder trouw een verloren voorwerp op eenẹ markt hẹt gekocht. 
goeder trouw bezit, ondersteld ook eigenaar te zijn, zoodat, bij revindicatie, de eischer zijn eigendom zal hebben te bewijzen. Dan echter loopt het proces niet, gelijk bij ons, over twee rechten, maar over de vraag wie van beiden inderdaad eigenaar is. Op grond van zijn bezit alleen, d.w. z. zonder tevens te beweren eigenaar te zijn, kan niemand eene zakelijke actie, tegen wien, of op welke wịzze ook, instellen.

Daarentegen zijn als afwijkingen, die in het Javaansche rechtsbewustzijn haren grond vinden de volgende rechtsbeginselen te beschouwen, bij de bespreking van welke ik de afwijking omtrent de zaken buiten den handel, als reeds vroeger in dit opstel besproken, thans niet meer behoef uiteen te zetten ${ }^{1}$.

De zakelijke rechten op gebouwen en beplantingen, afgescheiden van den grond, waarop zij staan, is niet alleen mogelijk ten aanzien van grond, waarop eigendomsrecht (Arab. milk, Mal. Jav. Soend. milik) wordt uitgeoefend, doch ook ten aanzien van grond, waarop de bezitter slechts gebruiksrechten, zakelijke zoowel als contractueele, heeft ${ }^{2}$. Zoo ook kan niet alleen grond in de

1 Zie boven, p. 95 .

${ }^{2}$ Intusschen is, voor de uitoefening van zakelijke rechten op gebouwen en beplantingen, afgescheiden van het recht op den grond, volgens den Islâm zoowel als naar inlandsche begrippen, noodig, dat de rechthebbende op den grond tot het bouwen of planten vergunning hebbe gegeven, dan wel die gebouwen of beplantingen afgescheiden van den grond hebbe overgedragen. Vergl. Soerjå Ngalam, p. 42, en de vonnissen van den Raad van Justitie te Batavia dd. 13 Juli 1872 en 21 Dec. 1873 (Ind. Weekbl. v. h. R., Nos 480 en 556). Dit laatste wordt in sommige streken ondersteld bij den verkoop van een nip a h-bosch; doch anders moet de grond uitdrukkelijk worden gereserveerd door den verkooper. Vergl. Eindresumé, dl. I, p. 215. De gebouwen en beplantingen, afgescheiden van den grond bezeten, zijn vatbaar voor alle overeenkomsten, bv. voor verhuur. Vergl. Sollewijn Gelpke, t. a. p., p. 577. Dat de grondbezitter zelf zijne gebouwen of beplantingen, afgescheiden van den grond, niet slechts kan vervreemden, maar ook verpanden, verhuren of legateeren, is natuurlijk. Vergl. Eindresumé, dl. I, p. 185. Evenals in het Mohammedaansche recht keert de grond, na het verlaten, weg. nemen, invallen of uitsterven der gebouwen of beplantingen, vrij tot den erfelijken bezitter terug. Vergl. Eindresumé, dl. I, p. 177, 186, 215. Vergl. overigens, voor de litteratuur en de jurisprudentie over den rechtstoestand van aan inlanders toebehoorende gebouwen en beplantingen, zonder een zakelijk recht op den grond, Mr. J. H. Abendanon: Nederlandsch-Indische rechtspraak, vo ce Opstal. In de praktijk worden deze inlandsche opstallen als roerend goed verpand, overgedragen en in beslag genomen, ofschoon uit een juridisch oogpnnt hiertegen veel te zeggen valt. Het is een specifiek Indische rechtstoestand, welke vooral aanleiding geeft tot twijfel, wanneer daarbij, aan het Europeesche vermogensrecht onderworpen, Vreemde Oosterlingen zijn betrokken. Het Indische Burgerlijk Wet- 
doode hand (Arab. waqf, Mal. Jav. Soend. wa kap) worden gebracht, waarvan men eigenaar is, gelijk in den Islâm, maar ook grond, waarop men gebruiksrechten uitoefent, mits in dit geval de gebruiksrechten, een zakelijk karakter dragen. Het brengen van roerende goederen in de doode hand bepaalt zich tot boeken, handschriften, lampen, en andere in de bedehuizen benoodigde zaken, welke aldaar tot voortdurend gebruik worden geplaatst. Soms wordt ook wel geld in de doode hand gebracht; maar dan is het onder de voorwaarde, dat het in onroerende goederen zal worden belegd. Het brengen van goederen in de doode hand betreft bijna altijd, wat wij eene "vrome stichting" zouden noemen, hetzij dat het doel der stichting bestaat in het gebruik der zaak zelf, bv. eene waterleiding of een bedehuis, dan wel dat het doel moet worden bereikt door de inkomsten der zaak daartoe aan te wenden, bv. een stuk grond, waarvan de opbrengst strekt tot onderhoud van een bedehuis of van de daaraan verbonden geestelijken. In het eerste geval spreekt men van wakap djama (Arab. waqf 'alâ $\mathrm{dj} a \mathrm{~m}$ '), indien de grond zelf in de doode hand wordt gebracht, en van amal (Arab. 'amal, d.i. "goed werk"), indien het brengen in de doode hand slechts op de gebouwen of de beplantingen afgescheiden van den grond betrekking heeft, en de grond zelf later tot den stichter of zijne nakomelingen moet terugkeeren. In het tweede geval spreekt men van wakap milik (Arab. waqfal-milk). Het maken tot wak a p komt zelden, en dan nog het meest in WestJava, voor in de functie van een fideïcommissair verband ten behoeve van afstammelingen of andere familieleden. Het zich voorbehouden van de administratie door den stichter, of het benoemen van bewindvoerders, is dientengevolge even zeldzaam; want de administratie der goederen, met een bepaald vroom doel in de doode hand gebracht, behoort van rechtswege tot de bemoeienissen der geestelijkheid 1 of van de hoofden der zoogenaamde "vrije" dorpen. Ontginning geeft geen eigendom, doch slechts gebruiks-

boek immers, ten deze overeenkomende met het Nederlandsche, kent slechts zakelijke rechten op gebouwen of beplantingen, zonder een zakelijk recht op den grond, wanneer die gebouwen of beplantingen van den grond los zijn, of althans bestemd om daarvan naar believen los te worden gemaakt. Vergl. Opzoomer: Het Burgerlijke Wetboek verklaard, dl. III, p. 37 en vv.

1 Sommigen der wakap's op de hoofdplaatsen zijn zelfs ten name der geestelijkheid ingeschreven in de registers van Europeesch eigendom, volgens Ind. Stbl. 1834 No 27. 
recht, hetzij tijdelijk, hetzij erfelijk, naar het in de streek geldende gewoonterecht. Het tijdelijke gebruiksrecht kan al dan niet zakelijk zijn ${ }^{1}$; het erfelijke is altijd zakelijk. Van het recht van naasting vinden wij alleen in eene enkele streek van MiddenJava sporen, en wel niet ten aanzien van mede-eigenaars, maar van dorpsgenooten, wanneer een tot het dorp behoorend erfelijk individueel bezeten grondstuk aan een niet-dorpsgenoot wordt verkocht. Tengevolge van de afwijkende inrichting der Javaansche dorpen, kunnen de voorschriften, door de Arabische juristen gegeven ten aanzien van de rechten en verplichtingen tusschen naburige woningen, geene toepassing vinden. Daarentegen is, althans in de Vorstenlanden, de blijkbaar aan het Hindoe-recht ontleende vordering tot afscheiding van erven implicite erkend, over welke rechtsvordering de Arabische juristen het stilzwijgen bewaren ${ }^{2}$. De individueele rechten op waterwerken en op het daardoor verkregen water, welke in den Islâm zoo sterk op den voorgrond treden, vindt men alleen in West-Java, op Madoera en in de Madoereesche streken van Oost-Java geëerbiedigd. In de overige gedeelten van Java wordt het irrigatierecht door het gemeenteverband beheerscht ${ }^{3}$.

Zoo ook is het een op Java en Madoera van ouds bestaan hebbend begrip, dat de vorst eivielrechtelijk eigenaar is van allen grond in zijn gebied, zonder dat dit eigendomsrecht beperkt wordt door eenig zakelijk, maar slechts door een contractueel recht van de opgezetenen, eene instelling met het Mohammedaansche recht onvereenigbaar, en in elk geval daarin absoluut onbekend. In West-Java is onder den invloed van den Islâm deze rechtstoestand reeds sedert lang veranderd, en vindt men het zakelijke bezitrecht der opgezetenen van ouds erkend, tegenover het eigendomsrecht van den vorst. In Midden- en Oost-Java en op Madoera is deze

${ }^{1}$ Een tijdelijk zakelijk gebruiksrecht ontstond door ontginning in de streken, waar nieuw ontgonnen bouwgronden van rechtswege na zekeren termijn in het communale bezit werden gebracht. Een tijdelijk en niet-zakelijk gebruiksrecht is het gevolg van ontginning in de Vorstenlanden. Zie over beide onderwerpen beneden, $\S \S 9$ en 14.

2 Vergl. Angg. Sad., art. 41, en Manoe, VIII: 245 en vv.

s Vergl. voor alle deze afwijkingen: Eindresumé, dl. I, p. 21, 45, 46, 64, 65, 100 en vv., 132,177 en vv., 183 en vv., 190, 209, 214 en vv., dl. II, p. 329 en vv., 333 en vv.; Resumé van Bantam, p. 142 en vv.; Minhâdj aț-Ṭâlibîn, dl. I, p. 396 en vv., dl. II, p. 28 en vv., 120 en vv., 171, 179 en vv., 182 en vv.; Fath al-Qarîb, p. 311; Mâwardì, p. 299; Mohammedaansche geestelijkheid, enz., p. il, 35 en vv. 
rechtstoestand eerst wettelijk afgeschaft door de invoering der Agrarische Wet (Indisch Stbl. $1870 \mathrm{~N}^{\circ}$ 55). In de Vorstenlanden bestaat de toestand nog ${ }^{1}$.

Intusschen hebben zoowel de Moḥammedaansche als de specifiek inlandsche begrippen omtrent eigendom sedert 1870 , ten aanzien van onroerende goederen, in ons rechtstreeksch gebied hun practisch belang geheel verloren. Nadat immers reeds bij Indisch Stbl. 1836 No 19 omtrent de inlandsche rechten op den grond, behoorende tot de zoogenaamde particuliere landerijen bewesten de rivier Tji Manoek, was uitgemaakt, dat die rechten geen eigendom waren, maar slechts zakelijke gebruiksrechten op den grond van den landheer, ging de Agrarische Wet (Ind. Stbl. 1870 No 55) van het beginsel uit, dat alle grond, waarop niet door anderen recht van eigendom bewezen wordt, in Nederlandsch-Indië, in ons rechtstreeksch gebied, in eivielrechtelijken zin staatsdomein is. Dit eigendomsrecht van den staat werd nader in wettelijken vorm voor Java en Madoera uitgesproken bij art. 1 van het zoogenaamde Agrarische Besluit (Ind. Stbl. $\left.1870 \mathrm{~N}^{\circ} 118\right)^{2}$, doch wordt, voor zooverre het gronden geldt, door inlanders voor eigen gebruik ontgonnen, of als gemeene weide of uit eenigen anderen hoofde tot de dorpen behoorende, beperkt door het hun op die gronden toegekend, hetzij individueel, hetzij communaal, maar in elk geval zakelijk bezit- of gebruiksrecht. Hiermede is dus uitgemaakt, dat de nationale rechten van den inlander op den grond altijd zijn ju ra in re aliena, en dat de eenige grondeigendom, welke particulieren in ons rechtstreeksch gebied, zonder onderscheid van landaard, kunnen uitoefenen, is de eigendom, overeenkomstig het Indische Burgerlijk Wetboek verkregen, en overeenkomstig Ind. Stbl. 1834 No 27 geconstateerd. Voor dien eigendom nu is de inlander, naar de hierboven uiteengezette onderscheidingen ${ }^{3}$, aan het Europeesche recht onderworpen. Onafhankelijk dus van de vraag, welke oorspronkelijk de aard was der inlandsche grond-

1 Vergl., voor de bewijsplaatsen en voor de historische ontwikkeling van een en ander, mijn meergeciteerd opstel over het eigendomsrecht van den staat op den grond op Java en Madoera, passim.

${ }^{2}$ Krachtens Ind. Stbl. 1875 No $199 a$ is bedoeld artikel ook van toepassing in de Buitenbezittingen, behoudens het ook voor Java en Madoera geldende voorschrift van art. 27 al. 2 van het Regeeringsreglement.

s Zie boven, p. 86 en vv. 
rechten ', hebben in elk geval thans het Mohammedaansche eigendomsrecht en de afwijkingen daarvan op Java en Madoera aldaar nog slechts ten aanzien van roerende goederen practisch belang ${ }^{2}$.

Ditzelfde geldt voor de Vorstenlanden, aangezien de eenige grondeigendom, welke aldaar bestaat, die is van den vorst, en van het Gouvernement, gelijk mede van de Gouvernementsonderdanen, wier eigendomstitels overeenkomstig het Indische Burgerlijk Wetboek zijn verkregen, en overeenkomstig Ind. Stbl. 1834 No 27 zijn geconstateerd. Op laatstgenoemde perceelen is wederom het Europeesche recht, naar de evenbedoelde onderscheidingen, toepasselijk.

Ook de inlandsche begrippen omtrent de bevoegdheid tot ontginnen van woesten grond, en omtrent den aard van het recht op den grond, door ontginning verkregen, hebben, sedert de regeling dezer aangelegenheid bij Ind. Stbl. 1874 No 79, opgehouden haar te beheerschen in ons rechtstreeksch gebied. Aldaar geeft ontginning, mits onder de bij bedoelde ordonnantie gevorderde voorwaarden tot stand gekomen, thans overal een erfelijk en zakelijk gebruiksrecht ${ }^{3}$.

Daar nu door den Europeeschen wetgever wel het zakelijke karakter van het inlandsche bezit- of gebruiksrecht op domeingrond is uitgemaakt, maar overigens dat recht in hoofdzaak nog steeds, ten aanzien van den omvang, de wijze van verkrijging of verlies, de bevoegdheid tot beschikking en de lasten jegens de gemeente of den lande, beheerscht blijft door de nationale inlandsche instellingen, zoo vormen de rechten op den grond op Java en Madoera een hoogst merkwaardig mozaïek van inlandsch en Europeesch

1 In mijn evenaangehaald opstel over het eigendomsrecht van den staat, enz. heb ik trachten aan te toonen, dat die rechten van ouds nergens op Java en Madoera overeenkwamen met het Moluammedaansche of Europeesche eigendomsrecht, maar in West-Java hoogstens zakelijke gebruiksrechten op domeingrond, en elders slechts contractueele gebruiksrechten op domeingrond waren.

${ }^{2}$ De zoogenaamde agrarische eigendom blijft hier, ofschoon een uitsluitend voor inlanders in het leven geroepen recht, buiten sprake, omdat bedoeld recht geene schepping van het nationale rechtsbewustzijn der bevolking, maar eene schepping van het Europeesch gezag is. Vergl. Agr. Wet, al. 4, en Ind. Stbl. 1872 No 1i7. De instelling heeft bovendien nimmer beantwoord aan de verwachtingen daarvan gekoesterd. Vergl. voor de oorzaken van dit verschijnsel, Eindresumé, dI. III, p. 166 en vv.

s Vergl. ook al. 3 der Agrar. Wet. 
recht, waarvan ik wil trachten in de volgende bladzijden de leidende beginselen onder juridische formules te brengen '.

De rechten, waarvan hier sprake is, kunnen worden onderscheiden als volgt:

a. de rechten, door de inlandsche bevolking uitgeoefend op het staatsdomein ;

b. de rechten, door de inlandsche bevolking uitgeoefend op den grond, behoorende tot de zoogenaamde particuliere landerijen en de erfpachtsperceelen;

c. de rechten, door de inlandsche bevolking uitgeoefend op den grond in de Vorstenlanden.

Wat de rechten betreft op het staatsdomein uitgeoefend, zoo valt wederom te onderscheiden tusschen:

$1^{\circ}$ het erfelijk individueele bezit- of gebruiksrecht;

$2^{\circ}$ het communale bezit. of gebruiksrecht;

$3^{\circ}$ het bezit- of gebruiksrecht krachtens het ambt;

$4^{\circ}$ het bezit- of gebruiksrecht op de begraaf platsen, de erven der moskeeën en de andere gewijde gronden ${ }^{2}$.

\section{$\S$ 9. ERFELIJK INDIVIDUEEL BEZIT- OF GEBRUIKSRECHT.}

Het erfelijk individueele bezit- of gebruiksrecht is een zakelijk recht, dat door inlanders wordt uitgeoefend op domeingrond, door

1 Hoe vele en hoe verdienstelijke geschiften over het inlandsche grondbezit op Java en Madoera ook verschenen zijn, zoo heeft toch, voor zooverre mij bekend, eene dergelijke algemeene synthetische behandeling daarvan nog nimmer plaats gehad.

2 Vergl. art. 2 van Ind. Stbl. 1874 No 79. De redactie van dit artikel is uit een juridisch oogpunt niet gelukkig. Zoo is niet alleen de grond, „door inlanders voor eigen gebruik ontgonnen", aan het ontginningsrecht van anderen onttrokken, maar natuurlijk evenzeer vroeger ontgonnen grond, door koop, erfenis, enz. in handen der bezitters gekomen. En toch kan men moeielijk in dat geval van eene ontginning „voor eigen gebruik" spreken. Dezelfde onjuistheid komt trouwens voor in al. 3 der Agrarische Wet, hetgeen des te meer treft, omdat in al. 4 dier Wet de goede uitdrukking : "grond door inlanders in erfelijk individueel gebruik bezeten", voorkomt. Voorts mist, in het even aangehaald art. 2, de onderscheiding tusschen „ontgonnen grond" en "woonerven" alle beteekenis; terwijl eindelijk „gewijde gronden" niet behoorden te zijn overgesteld tegen „begraafplaatsen” en „erven der moskeeën", daar immers ook de eerstgenoemden dikwijls, en de laatstgenoemden zelfs in den regel "gewijde gronden", d. w. z. wakap's, zijn. 
hen metterdaad bebouwd of beplant ${ }^{1}$. Het recht ontstaat primitief door inbezitneming, d. w. z. door ontginning van woesten grond, mits die ontginning hebbe plaats gehad overeenkomstig de wettelijke voorschriften ${ }^{2}$. Het is vatbaar voor overdracht onder de levenden en voor overgang bij wege van erfrecht of legaat ${ }^{3}$, voor verhuur en voor pand, en het kan in de doode hand worden gebracht, alles onder de beperkingen bij deze instellingen uiteengezet, en waarnaar hier wordt verwezen ${ }^{4}$. Behalve in de residentie Madioen, waar ten deze verschil van opvatting schijnt te bestaan, rekent men algemeen, dat de erfelijke bezitter eveneens zijn recht kan uitoefenen op de strook, waarmede zijn grond door aanslibbing vergroot is, mits hij dat recht door eenig teeken van inbezitneming kenbaar make 5. Hetzelfde beginsel wordt gehuldigd ten aanzien van grondstukken, door de kracht van het water van den eenen oever der rivier overgebracht naar den anderen, behalve in WestJava, alwaar het recht van den bezitter op zoodanigen grond blijft voortduren, althans wanneer op het afgespoelde stuk teekenen van beplanting zichtbaar gebleven zijn ${ }^{6}$.

De algemeene naam voor het erfelijk individueele bezit- of gebruiksrecht is in het Maleisch en Soendaasch: jasa, en in het Javaansch: jåså. In Bantam bezigt men ook het woord o esaha, en in de Preanger ook het woord pribadi. Wat den aard van het recht betreft, valt op te merken, dat, naar de inlandsche begrip-

1 Men kan het recht niet alleen tegenover derden, maar ook tegenover den staat, d. w. z. den eigenaar, handhaven. Zie Agrar. Wet, al. 3. Het recht houdt stand, zelfs indien het Gouvernement het stuk van het staatsdomein, waarop het wordt uitgeoefend, aan een derde verkoopt. Aldus besliste o. a. het Hoog Gerechtshof van N. I. bij arrest van 5 Oktober 1882 (Ind. Weekbl. v. h. R., No 1009)

2 Ind. Stbl. 1874 No 79 , art. 7.

${ }^{3}$ Aan den overgang op erfgenamen of legatarissen is het vermoedelijk toe te schrijven, dat men veelal het individueele bezit- of gebruiksrecht als "erfelijk" betitelt. Ofschoon deze bijvoeging $\mathrm{m}$. i. op zich zelf niet is aan te bevelen, zoo wil ik haar toch behouden, om niet in strijd te komen met het gevestigde spraakgebruik.

4 Vergl. Eindresumé, dl. I, p. 18, dl. II p. 333; De residentie Kadoe naar de uitkomsten der statistieke opname (Batavia 1871), p. 130, 131; Familie- en erfrecht p. 477, 478 en 506, en zie boven, p. 99 en vv., 108, 114 en 121.

5 Vergl. Eindresumé, dl. II, p. 331. De aldaar in noot $c$ gedane verwijzing naar $\S 10$ van het Overzicht van Soerabaja moet, blijkens het te dier plaatse vermelde, in omgekeerden zin worden opgevat; terwijl ook de mededeeling, dat in Madioen slechts in twee dorpen de aangeslibde grond aan den lande toebehoort, in strijd is met de geciteerde $\S 18$ van het Overzicht dier residentie.

${ }^{6}$ Ibid. p. 332. 
pen, het recht minder betrekking heeft op den grond zelf, dan wel op hetgeen van den grond is gemaakt, en op of in den grond is gebouwd, aangelegd of gedaan. Wanneer dan ook in Bantam en de Preanger-Regentschappen van milik (Arab. milk, d.i. "eigendom") wordt gesproken, heeft dit woord niet de beteekenis, welke wij en de Arabische juristen daaraan hechten, namelijk de eigendom van den grond in abstracto, maar hebbe men veeleer te denken aan den eigendom van hetgeen door werkzaamheid aan den grond is toegebracht. Dat bij vele bezitters dit begrip niet scherp van het recht op den grond zelf wordt onderscheiden, ligt in den aard der zaak. Immers valt de uitoefening van het recht op hetgeen aldus met den grond verbonden is, in de practijk feitelijk met de uitoefening van het recht op den grond samen. Dat speciaal in West-Java, onder den invloed van het Moḥammedaansche recht, de band tusschen de jas a en den grond nauwer werd dan elders, waar dat recht minder in het bewustzijn der bevolking was ingedrongen, is niet meer dan natuurlijk. Evenmin behoeft het, na het hierboven aangevoerde ${ }^{1}$, nader betoog dat, toen in de overige deelen van het eiland en op Madoera de bevolking nog slechts een contractueel recht op den grond bezat, de jas a aldaar hetzelfde rechtskarakter droeg, als bv. bij ons de verbeteringen door een huurder aan een vast goed aangebracht. De teekenen, dat de grond $\mathrm{jas}$ a is, noemt men tjiri of kitri. Men verstaat daaronder, bv. bij sawah's, de dijkjes, bij al wat geplant wordt, den boom of den struik zelf, bij een erf, de opgeworpen grond tot gelijkmaking van den bodem; soms ook het huis, en bij alle gronden, zonder onderscheid, de grensteekenen of afpalingen. De tjiri's of kitri's zijn dus de dragers van de jasa ${ }^{2}$.

1 Zie boven, p. 136.

2 Vergl. Eindresumé, dl. I, p. 3, 4, 18, 47, dl. II, p. 333 en vv.; De residentie Kadoe, enz., p. 128; Eigendomsrecht van den staat, enz., p. 23, 24, 26; art. 1603 Ned. Burgl. Wb. $=1567$ Ind. Burgl. Wb. Het begrip, dat de grond op zich zelf, d. w. z. onafhankelijk van hetgeen daaraan door menschenhanden is gedaan, geene waarde heeft, is een logisch gevolg van den overvloed van grond. Wij vinden dit begrip dan ook elders terug, waar hetzelfde feit zich voordoet, bv. op het schiereiland Malakka, waar verkoop van grond als poelang b̆̌landja d. i. terug erlangen van het daaraan ten koste gelegde, wordt omschreven Vergl. W. E. Maxwell: Laws and customs of the Malays with reference to the tenure of land, in het Journal of the Straits Branch of the R. A. S., Jaarg. 1884, p. 121. Zie ook Newbold: Account of the British settlements, enz., dl. II, p. 254. Zie, voor hetzelfde begrip in den aanvang der Middeleeuwen in Europa, Maine, t. a. p., p. 151, waar zeer juist gezegd wordt: The true difficulty of those days was not to obtain land, but to obtain the means of cultivating it. 
Behalve de reeds meermalen genoemde beperkingen van het beschikkingsrecht over erfelijk individueel bezeten gronden, en van de bevoegdheid om die door erfrecht te verkrijgen, tengevolge van gemeentelijke instellingen, wordt ook de uitoefening zelf van het recht op den grond overal min of meer, maar in Midden-Java het sterkst, door bedoelde gemeentelijke instellingen aan banden gelegd. Het erfelijk individueele bezit- of gebruiksrecht draagt dus op Java en Madoera een meer beperkt karakter dan het erfelijke gebruiksrecht of, gelijk zij het noemen, de "eeuwige huur", der Arabische juristen, die een beheerschen daarvan door het gemeenteverband niet kennen. Waar op Java en Madoera erfelijk individueel bezitrecht bestaat, is dan ook wel het gemeenteverband, waaronder de grond ligt, in zooverre verbroken, dat de grond niet meer tijdelijk onder de gemeenteleden wordt verdeeld, maar geenszins in die mate dat het systeem van solidariteit van privaatrechtelijke belangen tusschen de gemeentenaren zoude zijn verlaten, om, gelijk bv. in Nederland, daarvoor een zuiver staatsrechtelijken band tusschen hen in de plaats te stellen ${ }^{1}$. Zoo brengt de aard der sawah's van zelve mede, dat de bewerking daarvan af hangt van de waterverdeeling en dat, waar die waterverdeeling bij het dorpsbestuur berust, de exploitatie van genoemde velden steeds min of meer een gemeenschappelijk karakter moet dragen, en onder den invloed van het dorpsbestuur plaats vindt. En aangezien slechts in West-Java de individueel bezeten leidingen en waterwerken eenige beteekenis hebben, zoo volgt hieruit, dat bedoelde invloed van het dorpsbestuur zich in verreweg de meeste streken overwegend doet gelden. Voorts bestaat in Midden-Java in de meeste streken het bewustzijn, dat, ofschoon de woonerven heeten in erfelijk i ndividueel bezit te zijn, toch de grond, waarop het dorp gebouwd is, in haar geheel aan de gemeente als rechtspersoon is gebleven. Een gevolg hiervan is, dat, wanneer, tengevolge van vermeerdering van ingezetenen, nieuwe erven moeten worden gevormd, en daarvoor de grond niet op andere wijze kan worden verkregen, het dorpsbestuur bevoegd is om de grootste erven in te korten, en van de aldus vrij vallende stukken nieuwe erven te vormen. Voorts bestaat overal de verplichting om den grond overeenkomstig zijne bestemming te bebouwen of te gebruiken. De dienstplichtigheid, welke op den grond rust, is mede overal in meerdere of

1 Eene gelijksoortige opmerking ten aanzien van Britsch-Indië maakte reeds H. S. Maine: Village communities, $3^{\text {de }}$ druk, p. 109. 
mindere mate eene oorzak van beperking in de uitoefening van het bezitrecht, en zulks niet slechts, waar het de vervreemding geldt, maar ook wanneer de bezitter wegens ziekte of ouderdom ophoudt de diensten te kunnen praesteeren, dan wel om andere redenen ophoudt tot den stand der dienstplichtigen te behooren. Hij is dan genoodzaakt, ò zich van den grond te ontdoen, zoodanig dat deze in handen van een valieden persoon komt, òf een vervanger te stellen, die hem veelal een groot gedeelte van de opbrengst van den grond zal kosten. Eindelijk moeten als beperkingen van het erfelijk individueele bezit, tengevolge van gemeentelijke instellingen, in herinnering worden gebracht: de voorwaarde van ingezetenschap der gemeente, waaraan op vele plaatsen de uitoefening van het grondbezit is gebonden; het in vele streken van Midden-Java bestaand verbod, dat ingezetenen meer dan één woonerf bezitten ${ }^{1}$; het, vooral in de residentie Soerabaja, maar ook elders, bestaand verbod om, zonder voorkennis van het dorpshoofd, zekere boomen of bamboe op zijn erf te kappen; de verplichting om, ingeval van bezit van meerdere erven, te zorgen, dat allen bewoond zijn door personen in stat om de daarop rustende diensten na te komen; en de beperkingen van de straks te bespreken verandering in de bestemming van den grond. Niet nakoming van de op den grond klevende lasten heeft tengevolge, dat het erfelijk individueele bezit- of gebruiksrecht verloren gaat, al heeft in de meeste streken niet dadelijk ontzetting voor goed plaats, maar bepaalt men zich, om te beginnen, tot dwangmaatrelen, dan wel tot eene tijdelijke ontzetting uit het bezit ${ }^{2}$.

Hierboven ${ }^{3}$ is gezegd dat de ontginning moet voldoen aan de

1 Vergl. Eindresumé, dl. I, p. 145 , dl. II, p. 329 en vv., dl. III, p. 63 en vv.; Familie- en erfrecht, p. 477 en v., 506; Sollewijn Gelpke, t. a.p., p. 576 en v., en zie boven, p. 99 en vv. De in den tekst aangegeven lasten verschillen natuurlijk van plaats tot plaats, niet slechts wat den omvang daarvan betreft, maar ook ten aanzien van de soorten van gronden, waarop zij rusten. Wat de diensten aangaat, zoo blijkt uit de Bijlage $U$ van het Koloniaal Verslag van 1893, dat in 3965 gemeenten van Java en Madoera op het staatsdomein gelegen, de dienstplichtigheid uitsluitend op de bouwgronden, en wel speciaal op de sawah's rust, in 17460 gemeenten op de bouwgronden zoowel als op de woonerven, en in 9233 gemeenten niet alleen op de grondbezitters, maar op alle gegoede ingezetenen. Dat het recht van den bezitter af hankelijk is van de nakoming der op den grond klevende lasten, werd o. a. erkend in een vonnis van den Landraad te Grissee dd. 18 September 1880 (Ind. Weekbl. v. h. R., Jaarg. 1881, No 915).

2 Vergl. Eindresumé, dl. II, p. 342.

3 Zie p. 140. 
wettelijke voorschriften, wil men daardoor erfelijk individueel bezit van den grond verkrijgen. Die voorschriften zijn vervat in het reeds meer geciteerde Ind. Stbl. 1874 No 79, waarvan de volledige interpretatie niet tot ons onderwerp behoort. Alleen moet er op worden gewezen, dat daardoor in verschillende opzichten op het inlandsche gewoonterecht inbreuk is gemaakt. Zoo wordt in art. 1 het ontginnen zonder vergunning verboden, en zijn in de artt. 3 en 4 de autoriteiten aangewezen, die bedoelde vergunning zullen geven, gelijk mede de vorm waarin de vergunning wordt verleend. De artt. 6 en 7 bepalen, dat de vergunning eene voor overdracht vatbare bevoegdheid geeft tot ontginnen, maar dat het zakelijk recht van individueel bezit eerst verkregen wordt, wanneer aan alle voorwaarden der vergunning is voldaan, m. a. w. wanneer de ontginning is afgeloopen ${ }^{1}$. Door deze bepalingen is een einde gemaakt aan de verschillende opvattingen, omtrent bedoelde aangelegenheden vroeger bij den inlander bestaande, evenals indirect, d.w. z. door in de ordonnantie over de zaak te zwijgen, is beslist dat zijn afgeschaft de beperkingen der ontginning, o. a. ten aanzien van ingezetenen van andere gemeenten, en het recht op de aanhoorigheid van den ontgonnen grond, overeenkomstig de Moḥammedaansche wet, o. a. vroeger in Bantam en de Preanger erkend ${ }^{2}$. Bij art. 5 is verder imperatief en algemeen bepaald, dat bij de vergunning een termijn zal worden gesteld, waarbinnen de ontginning moet zijn tot stand gebracht, dat de grond dadelijk door duurzame grensteekenen $^{3}$ zal worden afgebakend, en dat, behalve de met

1 Het erfelijk individueele bezit, volgens de ontginningsordonnantie verkregen, is natuurlijk in elke gemeente onderworpen aan de daar bestaande speciale beperkingen van dat bezit, zoowel wat uitoefening, als wat overdracht betreft. Daarentegen is $\mathrm{m}$. i. door de ordonnantie stilzwijgend het tijdelijke karakter afgeschaft, hetwelk in vele streken het door ontginning verkregen gebruiksrecht oudtijds had, zoodanig dat na eenige jaren de nieuwe ontginningen in het com. munaal bezit terugvielen. Alleen wanneer dit uitdrukkelijk bedongen is, zal de ontginner voortaan nog ex contractu tot inbreng kunnen worden genoodzaakt. Zie, in denzelfden geest, H. E. B. Schmalhausen: Voorstel tot afschaffing der heerendiensten, enz. in de afdeeling Djombang (Soerabaja 1889), p. 76, 77. Over de thans dus opgeheven algemeene verplichting in vele streken met communaal bezit, om nieuwe ontginningen na een zeker getal jaren daarin te doen opnemen, vergl. Eindresumé, dl. I, p. 64, en v., 132.

2 In Bantam noemde men deze aanhoorigheden: oeloeran, en in de Preanger: harim, het laatste van het Arabische ḥa rîm afgeleid. Vergl. Minhâdj aț-Tâlibîn, dl. II, p. 172 en v.; Eindresumé, dl. II, p. 16, 46, 308 en vv.

${ }^{3}$ Het vroeger in vele streken bestaan hebbend gebruik, om als grensteekenen 
name genoemde voorwaarde van terrasgewijzen aanleg, ook nog zoodanige andere voorwaarden kunnen worden gesteld als plaatselijke omstandigheden wenschelijk maken. Intusschen moet de vraag, wanneer eene ontginning kan geacht worden te zijn afgeloopen, nog steeds worden beantwoord naar de Inlandsche rechtsbegrippen. Die rechtsbegrippen nu verschillen wel plaatselijk, wat de bijzonderheden betreft, maar komen toch overal daarin overeen, dat de groud in een staat moet zijn gebracht, welke onmiddellijke bebouwing toelaat, naar den aard van hetgeen men van den grond maken wil. De eerste werkzaamheden der bebouwing zelve zijn echter daartoe niet noodig. Zoo zal het voor een tĕg a l-veld voldoende zijn, dat het van boomen en struiken is gezuiverd, en de grond zoodanig is gelijk gemaakt, dat men met de bebouwing een aanvang kan maken. Geldt het eene sawah, zoo zal de grond waterpas moeten zijn gemaakt, en zullen de dijkjes moeten zijn gelegd, en de noodige werken, om het irrigatie-water er op te krijgen, moeten zijn tot stand gebracht. Het is echter niet noodig dat het veld beplant of beploegd zij ${ }^{1}$. Naar dezelfde beginselen zal men de vraag, of de ontginning is afgeloopen, bij andere bouwgronden, bij erven en bij vischvijvers, moeten beslissen ${ }^{2}$.

Met de ontginning hangt samen de zooeven reeds genoemde verandering in de bestemming van den grond. Dikwijls is die verandering van bestemming slechts eene voortzetting der ontginning, bv. indien men op woesten grond een tĕgal-veld aanlegt, en dit later tot eene sawah, een boomgaard of een woonerf maakt. Intusschen verbieden de woorden der meer geciteerde ontginningsordonnantie de daarin voorkomende bepalingen omtrent het vragen van vergunning, enz. ook op eene dergelijke verandering in de bestemming te doen slaan; maar dit doet niet te kort aan de beperkingen, waaraan de verandering in de bestemming ten gevolge van gemeentelijke instellingen is onderworpen. Die gemeentelijke

te bezigen merken op de hoekboomen, het wegkappen van eene strook gras, greppels, het samenbinden der takken van struiken, staken met bosjes alang. alang, enz., is dus thans niet meer voldoende.

1 Slechts zeer sporadisch wordt gevorderd, dat reeds met de eerste bebouwing een aanvang is gemaakt. Zie bv. Eindresume, dl. II, p. 75, 169, 205, 218, 252.

2 Vergl. Eindresumé, dl. II, p. 8 en vv., 26 en v., 37 en vv., 60 en vv., 74 en vv., 85 en vv., 105 en vv., 129 en vv., 145 en vv., 167 en vv., 187 en vv., 203 en vv., 216 en vv., 232 en vv., 250 en vv., 259 en vv., 266 en vv., 273 en v., 279 en v., 325 en vv.

fie Volgr. III. 
instellingen nu vorderen hier en daar zoo niet vergunning, dan toch kennisgeving aan het dorpshoofd voor het veranderen van tĕg a l's in sawah's, omdat daarmede het maken van eene nieuwe leiding of althans beschikking over het irrigatie-water gemoeid is, en dit in strijd zoude kunnen zijn met de verkregen rechten of de belangen van anderen. Daarentegen is algemeen vergunning noodig van het dorpshoofd voor het veranderen van bouwgrond in woonerven, en ongekeerd. Dit laatste is in sommige streken, bv. in Soerabaja, zoo niet geheel verboden, dan toch aan allerlei bezwarende voorwaarden gebonden '.

Het erfelijk individueele bezit- of gebruiksrecht gat verloren : $1^{0}$ door overdracht op anderen met inachtneming der beperkingen hierboven uiteengezet ${ }^{2}$;

$2^{\circ}$ door afstand ten behoeve van den staat, als eigenaar van den domeingrond ;

$3^{\circ}$ door onteigening ten algemeenen nutte en door beschikking ten behoeve van de op hoog gezag ingevoerde cultures tegen behoorlijke schadeloosstelling, volgens al. 3 der Agrarische Wet ${ }^{3}$;

$4^{\circ}$ door niet-nakoming van de verplichtingen aan het grondbezit verbonden, gelijk mede door de toepassing van de gemeentelijke regelingen houdende beperkingen in de bevoegdheid tot het uitoefenen van het recht op den grond, dan wel in de bevoegdheid tot erfopvolging, waarover hierboven gehandeld is ${ }^{4}$;

$5^{\circ}$ door het kennelijk verlaten van den grond ${ }^{5}$. In West-Java geldt omtrent gronden, welke op deze wijze onbeheerd (Mal. Jav.

1 Vergl. Sollewijn Gelpke, t. a. p., p. 577; Eindresumé, dl. I, p. 325, 326. De op laatstgenoemde plaats voorkomende mededeeling, dat "het bestuur", d. w. z. de Europeesche of inlandsche ambtenaren boven de dorpshoofden staande, toestemming moeten geven, is sedert de ontginningsordonnantie komen te vervallen, nu die ordonnantie de inmenging van "het bestuur" heeft beperkt tot de ontginning. De bevoegdheid der dorpshoofden ten aanzien van de verandering in de bestemming van den grond, is echter door de ordonnantie onaangetast gelaten.

${ }^{2}$ Zie boven, p. 99 en vv.

3 Door dit voorschrift zijn van zelve komen te vervallen alle, vroeger in zwang zijnde, wijzen van eigenmachtige beschikking over erfelijk individueel bezeten grond door het Europeesch of inlandsch bestuur voor den aanleg van wegen, dammen of waterleidingen, voor de verfraaiing of uitbreiding der hoofdplaatsen of dorpen, voor de uitbreiding van Europeesche of Chineesche wijken, voor cultures of zoutaanmaak, enz. enz. Vergel. Eindresumé, dl. II, p. 339 en v.

4 Zie boven, p. 142, 143, en vergl. Familie- en erfrecht, p. 477 en v. en 506 en v., alwaar tevens is uiteengezet, hoe met zoodanige vrijvallende gronden gehandeld wordt.

${ }^{5}$ Verg. art. 2, al. 2 van Ind. Stbl. 1874 No. 79. 
Soend. pĕlajangan) ${ }^{1}$ raken, de regel, dat de bezitter of zijne erfgenamen hun recht behouden, zoolang er teekenen van inbezitneming van den grond zichtbaar zijn. Zelfs bleek, bij het onderzoek in 1867 en 1868, in sommige dorpen van Bantam de meening te bestaan, dat de rechthebbenden, ook na het verdwijnen dier teekenen, den grond konden opeischen, natuurlijk mits zij het bewijs van hun recht konden leveren ${ }^{2}$. Ditzelfde begrip werd ook in eene enkele gemeente van de Preanger aangetroffen. Alleen dus, wanneer het verlaten van den grond met den uitgedrukten wil om daarvan afstand te doen had plaats gevonden, is verlies van het recht in bedoelde streken daarvan het gevolg. Elders, speciaal langs het Noorderstrand, treft men ook wel zeer sporadisch hetzelfde begrip aan; maar dit neemt niet weg, dat, naar het algemeene rechtsbewustzijn in Midden- en Oost-Java en op Madoera, het recht op den grond verloren gaat, hetzij onmiddellijk bij het staken der bebouwing, of bij het verlaten van de gemeente zonder orde op de exploitatie van den grond te hebben gesteld, hetzij nadat een zekere termijn, na het staken der bebouwing of het verlaten der gemeente, is verloopen. Die termijn is plaatselijk zeer verschillend, en hangt ook af van de bestemming van den grond. De kortste termijn is 2 , en de langste 9 jaar. Natuurlijk heeft dit alles geene betrekking op het verlaten met den uitgedrukten wil om afstand van den grond te doen, in welk geval het recht daarop dadelijk verloren gaat, zoowel in Midden en Oost-Java en op Madoera als in West-Java ${ }^{3}$.

Wanneer het recht op den grond, tengevolge van het verlaten, hoe dan ook, is te niet gegaan, wordt met dien grond gehandeld als met andere onbeheerde gronden ${ }^{4}$.

Daarentegen gaat het recht op den grond niet verloren, doordat daarover vroeger, hetzij met, hetzij tegen den wil des bezitters,

1 Van lajang, dus letterlijk: „Zwevend", eene uitdrukking vermoedelijk ontleend aan den Arabischen rechtsterm mauwqoef. In mijn Familie- en erfrecht, p. 506, staat abusievelijk plajangan, evenals trouwens in het Eindresumé.

2 Dit is geheel in overeenstemming met de Mohammedaansche wet. Zie Minhâdj aṭ-Tâlibîn, dl. III, p. 427,441 en vv.

s Verg. Eindresumé, dl. II, p. 340 en vv.

4 Zie, voor de wijze van beschikking over dergelijke gronden, Familie- en erfrecht, p. 506, 507. In West-Java en elders, waar het recht op den grond eerst na geruimen tijd verloren gaat, trekken wel de dorpshoofden zich de verlaten gronden aan, en zorgen zij in den regel dadelijk voor de exploitatie, maar meer als voorloopige maatregel, en als waarnemende de belangen van de eventueele rechthebbenden. Vergl. ook art. 231 Inl. Regl. 
door het dorpsbestuur of van hooger hand is beschikt ten algemeenen nutte, bv. voor het plaatsen van woningen, of het aanleggen van wegen, waterleidingen, enz. In al die gevallen, gelijk mede in de gevallen dat iemand uit eigen beweging aan anderen toestaat op zijn grond te bouwen of te planten, wordt de toestand beheerscht door de hierboven uiteengezette beginselen omtrent het recht op gebouwen of beplantingen afgescheiden van den grond, in verband gebracht met gemeentelijke regelingen of bijzondere bedingen ${ }^{1}$.

\section{§ 10. Communati Bezit- of gebruiksRecht.}

Het communaal bezit- of gebruiksrecht is een zakelijk ${ }^{2}$ recht, door de inlandsche gemeenten, als zedelijke lichamen, uitgeoefend op domeingrond. De gemeente kan over haar aldus bezeten grond niet beschikken, maar alleen de wijze regelen, waarop de ingezetenen daarvan het genot zullen hebben. De communaal bezeten gronden noemt men gewoonlijk: "grond van het dorp".

Tot deze dorpsgronden nu behooren in de eerste plaats de wegen, die ten laste zijn van de gemeente, alle binnen de kom der gemeente gelegen pleinen en openbare plaatsen, en, waar die bestaan, de gebouwen voor den publieken dienst van het dorp bestemd, voor zooverre bedoelde pleinen en gebouwen of plaatsen niet het karakter dragen van gewijde zaken of gronden, en onverminderd de rechten van bijzondere personen, op bedoelde wegen, pleinen, gebouwen of plaatsen verkregen, of ondanks hunne bestemming behouden. Van de hierbedoelde dorpsgronden is het gebruik altijd gemeenschappelijk. Het onderscheid van het Romeinsche en van ons recht tusschen zaken, welke staatsrechtelijk aan de gemeente behooren, en die waarvan de gemeente privaatrechtelijk eigenaresse

${ }^{1}$ Zie boven, p. 134, en vergl. Eindresumé, dl. I, p. 175 en vv., dl. II, p. 339 en v., dl. III, p. 159, 163. Ik geloof, met het in den tekst medegedeelde, de juridische formule te hebben gegeven, waaronder de vele feiten, in het Eindresumé ten deze vermeld, allen te brengen zijn. Sedert de af kondiging der Agrar. Wet is natuurlijk de beschikking over erfelijk individueel bezeten grond van hoogerhand, buiten het geval van onteigening of voor de cultures, uitgesloten, en dan nog is schadevergoeding noodig. Zie Agrar. Wet, al. 3.

2 Vóór de Agrarische Wet, contractueel. Zie boven, p. 136, en Eindresumé, dl. II, Bijlage L. 
is, wordt in het inlandsche rechtsbewustzijn niet teruggevonden ${ }^{1}$.

In de tweede plaats behooren tot de dorpsgronden de zoogenaamde gemeene weiden, welke eveneens in gemeenschappelijk gebruik der ingezetenen zijn. Soms behoort eene gemeene weide niet aan één, maar aan meerdere dorpen met gemeenschappelijk gebruik. Elders weder hebben wel meerdere dorpen het recht om van eene zelfde weide gebruik te maken, maar wordt die weide toch geacht slechts aan ééne dier gemeenten toe te behooren, en moeten de bewoners der andere gemeenten, voor de uitoefening van hun weiderecht, eene zekere vergoeding aan de betrokken gemeente of haar hoofd betalen. De gemeene weiden, waarvan hier sprake is, treft men het meest aan in de residentiën Pekalongan, Banjoemas, Bagelen en Rembang. Elders komen zij slechts sporadisch voor. Waar geene gemeene weiden bestaan, wordt het vee op den onbebouwden of braak liggenden grond geweid, dan wel op de bouwgronden, nadat de oogst gesneden is. Wat laatstgenoemde gronden betreft, zoo heeft natuurlijk de rechthebbende de bevoegdheid het weiden te verbieden, dan wel daaraan de voorwaarden te verbinden, welke hij goedvindt. Het weiden op onbebouwden of braakliggenden grond staat ieder vrij, behoudens zekere beperkingen ten aanzien van al ang-a lang velden ${ }^{2}$.

In de derde en voornaamste plaats behooren tot de dorpsgronden ook bouwgronden, woonerven, vischvijvers en nipah-bosschen. Wanneer men eenige vischvijvers in de Preanger-Regentschappen en Cheribon uitzondert, die gemeenschappelijk door de gemeenteleden worden geëxploiteerd ${ }^{3}$, zoo gaat, bij alle de hier genoemde vaste goederen, het communale bezit gepaard met individueel gebruik, d. w. z. zij. worden in aandeelen (bagian, bakon) verdeeld, welke aandeelen aan de rechthebbende gemeenteleden ter individueele exploitatie worden toegewezen voor korteren of langeren tijd. De gebruikers hebben dus op hun aandeel geen zakelijk recht, maar slechts eene persoonlijke aanspraak tegen de gemeente, welke op

1 Vergl. art. 2, al. 2 van Ind. Stbl. 1874 No 79; Gemeentewet, artt. 229, 230; Eindresumé, dl. I, p. 4, dl. III, p. 159, 163. Op beide laatstgeciteerde plaatsen wordt minder juist onderscheiden tusschen gemeenten, waar de grond voor de wegen, pleinen, enz. geacht wordt aan het Gouvernement, en die waar bedoelde grond geacht wordt aan de gemeente toe te behooren. Het eigendomsrecht van het Gouvernement sluit immers het gebruiksrecht van de gemeente niet uit.

2 Vergl. art. 2, al. 1 van Ind. Stlbl. 1874 No 79, en Eindresumé, dl. I, Bijl. A, dl. III, p. $145,146,159$.

s Vergl. Eindresumé, dl. I, p. 204, dl. III, p. 36, 59. 
hare beurt de gronden in quaestie bezit, niet om daarover naar welgevallen te beschikken, doch als eene soort van fonds ten behoeve van hare dienstplichtige ingezetenen ${ }^{1}$. Het communaal bezit van bouwgronden bestaat niet in de residentiën Bantam, Batavia, Krawang, Preanger-Regentschappen, Besoeki en Madoera. Dat van woonerven wordt daarentegen ook in onderscheiden gemeenten van Bantam en de Preanger-Regentschappen, en algemeen in het regentschap Banjoewangi aangetroffen. Communaal bezeten vischvijvers komen buiten Midden-Java slechts in eene enkele gemeente van de Preanger voor. In de streken, waar communaal bezit wordt aangetroffen, heeft men echter tevens individueel bezit, zoodat men kan zeggen, dat op Java en Madoera de beide soorten van bezit in totale uitgestrektheid thans nog ongeveer tegen elkander opwegen, al heeft laatstgenoemde soort reeds min of meer de overhand, en eene neiging om zich langzaam uit te breiden ${ }^{2}$.

Het communaal bezit, waarover hier gehandeld wordt, en dat in den vervolge alleen bedoeld zal worden, wanneer de uitdrukking zal worden gebezigd, is evenals trouwens de Javaansche naam voor "dorp" zelve, déså (N) of d̦ o e s e n (K), blijkbaar van Hindoeoorsprong. De instelling hangt samen met het wezen der aloude Arische dorpsgemeenschappen. De Moḥammedaansche wet zwijgt over het communaal bezit, ofschoon zij aan den anderen kant het ook niet verbiedt. Intusschen is deze bezitsvorm juist onbekend in de streken van Java en op Madoera, waar de Islâm de diepste wortelen geschoten heeft, en daarentegen van den grootsten omvang in die gedeelten van Java, waar de Hindoe-beschaving het grootst was. Zoo ook treft men de instelling thans nog onder de Hindoe's op het eiland Bali aan. Intusschen heeft, voor zooverre men kan nagaan, zelfs in streken met communaal bezit, daarnaast van ouds ook het individueele bezit bestaan ${ }^{3}$.

1 Vergl. Eindresumé, dl. I, p. 8.

${ }^{2}$ Vergl. Ibid. Bijl. A.; Koloniaal Verslag van 1893 , Bijl. U. De combinatie van individueel en communaal bezit doet zich voor in tweeërlei vorm. Er liggen namelijk soms gemeenten met uitsluitend individueel of met uitsluitend communaal bezit naast elkander, en soms treft men beide soorten van bezit in dezelfde gemeente aan.

s De dorpsgemeenschappen zijn van ouds in het Hindoe-recht bekend. Vergl. Manoe, VIII: 219 en B. W. Leist: Alt-Arisches jus gentium, p. 24 en vv. Zie over bedoelde dorpsgemeenschappen, en over die in Britsch-Indië in het bijzonder: Maine: Village communities, p. 18 en vv., 76 en vv., 103 en vv.; E. de Laveleye: De Ia propriété et de ses formes primitives, p. 4 en vv., 65 en vv., 349 en vv.; 
Het communaal bezit heeft de grootste uitbreiding ten aanzien van sawah's, vermoedelijk omdat deze uit den aard der zaak meer dan andere bouwgronden door gemeenschappelijken arbeid zijn ontgonnen, hetzij vrijwillig, hetzij op last van hoofden of ambtenaren, en omdat zij veelal door gemeenschappelijk aan-

over die in Rusland: K. Kawelin: Das bäuerliche gemeindebesitz in Rusland, (Leipzig, 1877), en over Bali: F. A. Liefrinck: Bijdrage tot de kennis van het eiland Bali, in het Tijdschr. v. Ind. Taal-, Land- en Volkenkunde, dl. XXXIII (1890), p. 390 en vv. Het verband der Javaansche dorpsgemeenschappen met de Arische dorpsgemeenschappen elders wordt o. a. ook erkend door wijlen den Hoogleeraar P. J. Veth en door Prof. Mr. P. A. van der Lith. Zie Java, dl. I, p. 354, en Nederlandsch Oost-Indië, 2de druk, dl. II, p. 228. Daarentegen wordt door anderen het communaal grondbezit op Java voorgesteld, niet als eene aloude volksinstelling, maar als eene vrucht van tallooze misbruiken, door Europeesche en Inlandsche bestuurders in vroeger eeuwen gepleegd, hetgeen in het Eindresumé zoude bewezen zijn. Zie Eindresumé, dl. II, passim, en De Louter, t. a. p., p. 587. Ik acht deze meening, yan hoe geachte zijde ook verkondigd, beslist onjuist. Het moge waar zijn, dat in vroeger tijd door Europeesche en inlandsche bestuurders in Midden-Java vele misbruiken zijn gepleegd, daarmede is, gelijk reeds de heer Van der Lith opmerkte, het ontstaan der instelling zelve, van het communaal bezit aldaar, in den Arischen vorm, niet verklaard. Bovendien blijft het alsdan, naar mijne meening, ten eenemale onbegrijpelijk, waarom gelijke oorzaken niet gelijke gevolgen hadden in West-Java en in de Madoereesche streken, waar de Hindoe.invloed het zwakst, en die van den Islâm het sterkst was. Om die zoogenaamde "misbruiken" naar billijkheid te beoordeelen, mag bovendien niet uit het oog worden verloren, dat het oudtijds in Midden-Java bestaan hebbend individueel bezit niet was, gelijk thans, en vroeger ook in West-Java, een zakelijk recht, maar louter eene contractueele aanspraak, eene soort van huur, opzegbaar door den eigenaar van den grond, d. w. z. door het Gouvernement. Door den grond voortaan aan de gemeente als zedelijk lichaam, in plaats van aan de individueele leden der gemeente. te verhuren, deden de vertegenwoordigers van het Gouvernement niet anders dan van een recht gebruik maken. Het misverstand is daaraan te wijten, dat de niet juridisch gevormde en, blijkens hunne eigene verklaringen, bijna allen met voorliefde voor het individueel bezit bezielde amb. tenaren, wier onderzoekingen de bouwstoffen voor het Eindresumé hebben geleverd, blijkbaar met het onderscheid tusschen zakelijke en contractueele rechten onbekend waren, en van "individueel bezit" in twee verschillende beteekenissen spraken. Ook bij ons immers is het "bezit" van den huurder individueel, evengoed als het "bezit" van den eigenaar, erfpachter, opstaller, enz. Alleen beteekent in het eene geval „bezit" iets anders dan in het tweede. Vergl. Eigendomsrecht, p. 16 en 26; De residentie Kadoe, p. 131; Eindresumé, dl. II, p. 355 en vv. Het bestaan van het communaal bezit onder de O. I. Compagnie is niet voor tegenspraak vatbaar. Zoo wordt in het rapport van Rothenbuhler dd. 19 April 1806 en Bijlagen, te vinden in dit Tijdschrift, dl. II (1854), p. 62 en vv. telkens onderscheiden tusschen de velden, die aan de opgezetenen individueel zijn toebedeeld, als op het eiland Madoera, en die aan de "negorijen" en bloc zijn uitgegeven ter verdeeling onder de ingezetenen, als in het Grisseesche. Zie t. a. p., p. 79 en vv., 
gelegde, of althans gemeenschappelijk onderhouden, waterwerken of leidingen worden geïrrigeerd. In den regel worden de communale sawah's verdeeld tusschen alle ingezetenen, die aan de vereischten voor aandeelhebber voldoen. Soms echter komt het voor, dat het moederdorp en de daaronder ressorteerende gehuchten elk afzonderlijk hunne communale sawah's hebben, welke respectierelijk worden verdeeld onder de ingezetenen van het dorp en van de gehuchten. Rechthebbenden op een aandeel zijn alleen de volle dienstplichtige mannen (sikĕp, gogol, koeli kĕntjĕng) en de hoofden en bestuurders der gemeente, voor zooverre deze geene vaste ambtsvelden of bijzondere aandeelen als zoodanig genieten. Ophoudende tot den stand der volle dienstplichtigen te behooren ${ }^{1}$, de gemeente verlatende, dan wel door overlijden, verliest men zijn

91, 99, 103, 107, 113. Vergl. ook het Rapport van denzelfden dd. 31 Dec. 1812 , te vinden in de Verhandelingen van het Bat. Gen. v. K. en W., dl. XLI (1881), p. 16, 30 en v.; het Rapport van den heer Mr, H. van Dissel over de particulierc landerijen beoosten de rivier Tji Manoek, in het Tijdschrift voor Nijverheid en Landbouw in Ned. Indië, dl. XXII (1878), p. 280, 281; Eindresumé, dl. II, 301; Raffles: Substance of a minute (Londen, 1814), p. 107, 129, 131. Zelfs in den Soerjå Ngalam vinden wij reeds eene plaats (p. 15), welke blijkbaar op gemeenschappelijk bezit van sawah's doelt. Trouwens, indien men zich, bij het lezen van het Eindresumé, aan de daarin medegedeelde feiten houdt, los van de aan die feiten vastgeknoopte beschouwingen, zoo blijkt wel, dat men in vele gemeenten in 1867 en 1868 nog wist van ontstaan of uitbreiding van het communaal bezit, tengevolge van het verlaten van gronden, overlijden zonder erfgenamen, volks verloop, bevelen van hooger hand, heeren- en cultuurdiensten, aanleg van waterwerken, gemeenschappelijke ontginning op last of vrijwillig, enz., enz; maar nergens werd verklaard, dat de instelling als zoodanig te voren in de streek onbekend was. Daarbij komt, dat in den tekst van het Eindresumé soms de in enkele gemeenten afgelegde verklaringen zijn gegeneraliseerd, zoodat men wel doet, steeds ook de noten te consulteeren; terwijl aan den anderen kant ook positieve verklaringen, dat men niet beter wist, of het communaal grondbezit had altijd bestaan, niet ontbreken. Zie, tot staving van het hier opgemerkte: Eindresumé, dl. II, p. 56 en vv., 70 en vv., 82 en vv, 100 en vv., 124 en vv., 142 en vv., 153 en v., 161 en vv., 182 en vv., 198 en vv., 213 en vv., 227 en vv., 247 en vv., 257 en vv. Wat intusschen van dit alles moge zijn, het communaal bezit bleek, bij het onderzoek in 1867 en 1868, waar het bestond, zoo zeer in het rechtsbewustzijn der bevolking te zijn doorgedrongen, dat zelfs tegenover daaraan vijandige ambtenaren, zoo niet alle, dan toch de meeste en voornaamste leden der gemeenten doorgaans verklaarden het te willen behouden. Zie Eindresumé, dl. II, p. 352 en vv. De betrekkelijk zeldzame gevallen van conversie in individueel bezit, sedert dat daartoe de bevoegdheid werd verleend, bewijzen, dat de geest der bevolking ten deze nog niet veranderd is.

1 De beantwoording der vraag, wie tot den stand der volle dienstplichtigen gerekend worden, beschouw ik als niet te dezer plaatse te huis behoorende. Vergl.
boven, p. 143 . 
aandeel na afloop van den oogst. In de gemeenten, waar de lasten, op het grondbezit klevende, niet opwegen tegen het voordeel, dat men uit een aandeel trekt, is het recht op een aandeel veranderd in eene verplichting van elk erfbezitter, ja niet zelden zelfs van elk werkbaar man, om een aandeel te nemen, en, als gevolg daarvan, in de lasten der gemeente bij te dragen. Deze ongezonde toestand is intusschen uitzondering; het meest komt hij nog voor in de residentiën Madioen en Kediri, waar de aandeelen zeer versnipperd zijn ${ }^{1}$.

In de meerderheid der gemeenten zijn de aandeelen vast, d. w. z. zij worden zoo lang mogelijk onveranderd in handen van dezelfde personen gelaten, en wijziging in de grenzen of verwisseling heeft alleen plaats om bijzondere redenen, als het uitvallen of bijkomen van aandeelhebbers, groot verschil in de productiviteit der aandeelen, verhuur van grond aan Europeanen, enz. In andere gemeenten echter heeft men periodieke verwisseling van aandeelen, hetzij om het jaar, hetzij na langere termijnen. Deze toestand heeft thans alleen nog in de residentiën Japara, Rembang, Madioen, Kediri en Soerabaja beslist de overhand; zij vertoont over het algemeen eene neiging om geleidelijk voor het communaal bezit met vaste aandeelen plaats te maken. Hetzij echter de aandeelen vast zijn, hetzij periodieke verwisseling plaats heeft, doorgaans zijn zij van ongeveer gelijke waarde, en rusten daarop gelijke verplichtingen. In Kediri echter, en voorts in vele gemeenten van Madioen en enkelen van Cheribon en Japara, zijn de aandeelhebbers in klassen verdeeld, die grootere of betere aandeelen bekomen, naar mate zij zwaardere diensten moeten doen. Vroeger was ditzelfde het geval in Rembang, ten aanzien van de veebezitters bij de, thans niet meer bestaande, zoogenaamde blanḍ ong-diensten ${ }^{2}$ ingedeeld. Bij uitzondering is ook wel de hoegrootheid of de waarde van het aandeel verschillend, naarmate men over meerdere middelen tot bebouwing kan beschikken, bv. omdat men veebezitter is, zonder dat daar tegenover grootere verplichtingen staan. Elders wordt wel eens aan een ingezeten een kleiner aandeel gegeven, omdat hij tevens sawah's in erfelijk individueel bezit heeft, en

1 Vergl. Eindresumé, dl. I, p. 59, 61 en vv., 69, 75, 77, dl. III, p. 139, 140; De residentie Kadoe, p. 132 en v.

2 Diensten bij de houtbosschen. In eenige gemeenten van Rembang is niettegenstaande de afschaffing dezer diensten, de bevoorrechting der veebezitters blijven bestaan. 
eindelijk geeft men in vele dorpen aan personen, die wegens hun leeftijd of om andere redenen hebben opgehoudeu dienstplichtig te zijn, een kleiner aandeel bij ẇege van pensioen. Dergelijke locale uitzonderingen op den regel van gelijke verdeeling zijn er meer. In zeer vele gemeenten wordt over de toelating van nieuwe aandeelhebbers door de gezamenlijke belanghebbenden beslist; elders ge schiedt zulks door het dorpshoofd, dat hoogstens van de toelating aan de andere rechthebbenden kennis geeft. Naarmate de aandeelen grooter, en de laslen daarop rustende naar verhouding minder drukkend zijn, is men met de toelating strenger, en moet de nieuweling aan allerlei voorwaarden, bv. van inwonerschap gedurende zekeren tijd, bezit van een erf, enz. voldoen ${ }^{1}$.

De afbakening en de toewijzing der aandeelen geschieden meestal bij onderling goedvinden der belanghebbenden onder de leiding van, en na voorafgaande opneming door het dorpsbestuur, dikwijls, waar periodieke verdeeling bestaat, volgens een rooster. In sommige streken evenwel geschiedt de afbakening, en in enkele anderen ook de toewijzing der aandeelen door het dorpsbestuur, ja zelfs door het dorpshoofd alleen, welke handelwijze vroeger vooral in Cheribon aanleiding tot vele misbruiken gaf. Bij de verdeeling wordt echter bijna overal ook min of meer rekening gehouden met persoonlijke aanspraken, bv. doordat men aan nakomelingen van ontginners bij voorkeur als aandeel de plek geeft door hun auteur ontgonnen, maar later in het communaal bezit gebracht, of doordat men zoons of schoonzoons in het aandeel van hun vader of schoonvader laat opvolgen, ja zelfs de weduwe in het aandeel van haar overleden man, mits zij zorgt, dat de diensten op het aandeel rustende worden nagekomen ${ }^{2}$. Tĕg a l's, tuinen en boomgaarden in communaal bezit zijn veel minder talrijk dan de communaal bezeten sawah's. In den regel treft men die niet aan in gemeenten, waar niet tevens communaal saw ah-bezit aanwezig is. Het aandeel daarin vormt veelal eene toegift op het saw ah-aandeel, dan wel het strekt om een minwaardig sawahaandeel aan te vullen. Het volgt dan in alle opzichten het rechtslot

1 Vergl. Eindresumé, dl. I, p. 61 en vv., 66 en vv.; De residentie Kadoe, p. 133, en het Kol. Verslag van 1893, Bijl. U. Blijkens laatstgenoemde Bijlage waren er, in 1892, 13201 gemeenten met vaste aandeelen, tegen 12429 in 1887. Zie Bijlage S van het Kol. Verslag van 1888.

${ }^{2}$ Vergl. Eindresumé, dl. I, p. 71, 73 en vv., dl. III, p. 256, 257; Sollewijn Gelpke: Naar aanleiding van Stbl. 1878 No 110 , dl. I, p. 48 en vv.; Poensen, t. a. p., dl. XXXVIII (1894), p. 100 en v. 
van het laatste. Ook komt het voor, dat men de aandeelen in de tĕgal's geeft aan personen, die de vereischten voor sawahaandeelhebber missen, en die men toch niet geheel wil voorbijgaan. Alleen in enkele gemeenten van Bagelen en Japara treft men het abnormale verschijnsel aan, dat de sawah's in individueel, maar de tĕgal's in communaal bezit zijn ' 1 .

Vischvijvers in communaal bezit bestaan slechts in de residentiën Preanger-Regentschappen, Cheribon, Japara en Rembang. In de beide eerste residentiën worden zij gemeenschappelijk door de ingezetenen geëxploiteerd; in de beide laatsten bestaat individueel gebruik. Daar de aandeelhebbers soms talrijker zijn dan de aan. deelen, waarin de vijvers kunnen worden gesplitst, zoo wordt vaak één aandeel aan twee of meer rechthebbenden te zamen ter exploitatie toegewezen, iets dat met aandeelen in bouwgronden nimmer het geval is. Dan heeft men, ò beurtregeling, òf exploitatie door één hunner, die de lasten draagt, welke op den vijver kleven, en, na aftrek der onkosten en eene billijke belooning voor zijne moeite, de netto-opbrengst deelt tusschen zich en zijne mede-aandeelhebbers. Het komt ook voor, dat een communale vijver aan den meestbiedende onder de aandeelhebbers wordt verpacht, en het ontvangen bedrag onder de anderen wordt verdeeld. Ook deze vorm van exploitatie is bij bouwgronden onbekend ${ }^{2}$.

Bij de weinige nipah-bosschen in communaal bezit, bestaat daarentegen weder uitsluitend individueel gebruik, meestal met vaste aandeelen. Alleen in de gemeenten, waar wilde nipah wordt aangetroffen, is deze ter beschikking van alle ingezetenen. Waar verdeeling in aandeelen bestaat, heeft men soms toewijzing van een aandeel aan meer dan één persoon, in welk geval de exploitatie door de tusschen hen aangegane overeenkomsten wordt beheerscht ${ }^{3}$.

$\mathrm{Bij}$ het communaal bezit der woonerven is het individueel gebruik wederom van anderen aard. Men beschouwt dan namelijk den grond, waarop de woningen staan, als gemeentegrond. Daarvan wordt aan elk gezinshoofd, die aan de locaal uiteenloopende vereischten voldoet om als ingezeten van het dorp te worden toe-

1 Vergl. Eindresumé, dl. I, p. 130 en vv., dl. III, p. 120, 160.

2 Vergl. Eindresumé, dl. I, p. 204 en vv., en zie boven p. 149.

3 Vergl. Eindresumé, dl. I, p. 217 en v. 
gelaten, een stuk aangewezen, om eene woning te plaatsen. Voor zooverre de plaatsing der woningen het gedoogt, mag hij op den hem toebedeelden grond tevens plantsoen aanleggen. Op dien grond heeft hij een gebruiksrecht, zoolang hij ingezetene is; terwijl wat daarop gebouwd of geplant is, zijn eigendom blijft. Over een en ander mag hij beschikken als over zijne andere goederen, behoudens dat hij, door verkoop van zijn huis, niet eigenmachtig een inwoner in de gemeente mag binnensmokkelen, die, op grond van de bestaande instellingen, er niet zoude kunnen worden toegelaten. Bij geoorloofden verkoop echter is de gemeente verplicht het gebruik van den grond aan den kooper van het huis of van den aanplant te laten, onverminderd het recht, dat de gemeente steeds behoudt om, ingeval van gebrek aan grond, de erven te verkleinen, voor zooverre dit mogelijk is met het oog op de bestaande gebouwen en beplantingen. Ook bij het bouwen van een nieuw woonhuis moet men zich in gemeenten, waar deze toestand bestaat, aan de bevelen van het dorpsbestuur omtrent ligging, grootte, enz. van de woning onderwerpen. Slechts bij hooge uitzondering en in streken, waar op de erven geen plantsoen staat, komt het voor, dat de gemeentelijke instellingen aan het dorpsbestuur de bevoegdheid toekennen, om bevel tot verplaatsing van woningen te geven. Trouwens, behalve in het regentschap Banjoewangi, wordt het communaal bezit van erven overal slechts zeer sporadisch aangetroffen '.

De voorwaarden, waaronder de meerderheid der deelgerechtigden de minderheid kan dwingen, om het communaal bezit van bouwgronden ${ }^{2}$ in individueel bezit te converteeren, zijn geregeld bij Ind. Stbl. 1885 No 102. Dat, bij eenstemmigheid der rechthebbenden, ook andere communaal bezeten gronden in erfelijk individueel bezit kunnen worden gebracht, en omgekeerd erfelijk individueel bezit in communaal bezit kan worden geconverteerd, volgt m. i. uit den omvang, welke de autonomie der gemeenten op Java en Madoera naar ons staatsrecht, gelijk mede naar de inlandsche instellingen, heeft ${ }^{3}$.

1 Vergl. Eindresumé, dl. I, p. 169 en vv.; Sollewijn Gelpke, t. a. p., p. 576, 577.

${ }^{2}$ De beperking tot bouwgronden staat uitdrukkelijk te lezen in art. 1. Woonerven, wegen, enz. vallen dus buiten het bewuste Koninklijk Besluit.

s Vergl. Familie- en erfrecht, p. 478, 479. 


\section{§ 11. BEZIT- OF GEBRUIKSRECHT KRACHTENS HET AMBT.}

Het bezoldigen van hoofden en van burgerlijke of militaire landsdienaren geheel of gedeeltelijk in land is, voor zoover men kan nagaan, eene instelling, van ouds op Java en Madoera in zwang, en ook door de Oost-Indische Compagnie in practijk gebracht. Dergelijke gronden bestonden vroeger, òf in geheele landstreken, òf in bepaalde dorpen met hunne gronden, ò in eene zekere uitgestrektheid bouwgrond. De beide eerstgenoemde vormen verdragen zich noch met de Mohammedaansche, noch met de Hindoe-wetten, welke, gelijk wij reeds vroeger zagen, den souverein alleen het recht toekennen de inning der hem verschuldigde belastingen bij wege van concessie (iq țâ') aan zijne ambtenaren of krijgsoversten te cedeeren, maar niet om over den grond te beschikken, door anderen in eigendom of in erfelijk gebruiksrecht bezeten. De laatstgenoemde vorm verdraagt zich daarentegen zoowel met den Islâm als met het Hindoe-recht, mits de afstand betrekking hebbe op bouwgronden, tot het vrije staatsdomein behoorende. Vermoedelijk zijn de beide eerstgenoemde vormen oorspronkelijk inlandsch,' evenals het geheele eigendomsrecht van den vorst op den grond. In het voormalige Bantamsche rijk en in de voormalige Madoereesche vorstendommen had het ambtelijk landbezit meer een Moḥammedaansch karakter, en kwam speciaal de beschikking over de dorpen slechts voor in den vorm van vergunning, om de aan den vorst toekomende diensten te genieten of opbrengsten te innen ${ }^{1}$.

In ons rechtstreeksch gebied op Java en Madoera, de PreangerRegentschappen uitgezonderd, werd het ambtelijk landbezit bij Ind.

1 Vergl. Sollewijn Gelpke: Naar aanleiding van Stbl. 1878 No 110, dl. I, p. 4; Het eigendomsrecht van den staat, enz., p. 5, 11, 14, en de daar geciteerde bewijsplaatsen, waarbij nog te voegen: Manoe, VII: 118 en vv., en, speciaal voor Bantam en Madoera: Eindresumé, dl. II, p. 3 en vv., 275 en vv.; Resumé van Bantam, p. 70; voor Midden-Java: Eindresumé, dl. II, p. 295 en vv., 288 en vv. en 295 en vv. Het landbezit, door de inlandsche vorsten aan landsdienaren, familieleden en grooten tot hun onderhoud toegekend, noemt men in de Indische administratieve taal gewoonlijk: "apanage", in tegenoverstelling van het ambtelijk landbezit van de hoofden en bestuurders der dorpen. Naar de inlandsche begrippen bestaat intusschen geen onderscheid in rechtskarakter of naam tusschen deze "apanages" en het landbezit als belooning voor het vervullen van gemeenteambten. In Bantam werden, onder het vorstenbestuur, de concessies niet met den Arabischen naam iqț â', maar met den Inlandschen pětjat on aangeduid. Op Madoera heetten zij pěrtjaton. 
Stbl. 1867 No 122 afgeschaft voor alle hoofden en ambtenaren, behalve voor de hoofden en bestuurders der gemeenten. Bij Ind. Stbl. 1870 No 122 werd dezelfde matregel tot de Preanger uitgestrekt, en, bij de overname der Madoereesche vorstendommen, Soemenep en Bangkallan, ook aldaar ingevoerd, behoudens het later te bespreken landbezit der zoogenaamde barissan ${ }^{1}$.

Het ambtelijk landbezit van de hoofden en bestuurders der Inlandsche gemeenten is, evenals die gemeenten zelve, op Java en Madoera stellig van Hindoe-oorsprong. Het feit, dat bedoeld landbezit zich van ouds nooit anders dan in den zooeven vermelden derden, met het Hindoe-recht overeenstemmenden, vorm heeft voorgedaan, dat het geheel met het gemeentewezen samenhangt, dat het zich juist in die streken van Java het sterkst ontwikkeld heeft, waar de Hindoe-invloed het grootst en de Mohammedaansche het geringst is geweest, en eindelijk de treffende gelijkenis met de toestanden in Britsch-Indië zijn hiervoor voldoende aanwijzingen ${ }^{2}$.

De meest gebruikelijke benaming voor de ambtelijk bezeten gronden is in het Javaansch: loenggoeh (N) of lĕnggah (K). Daarnaast zijn echter in Midden-Java de uitdrukkingen: bak on en bĕngkok in gebruik. In de Preanger spreekt men van sawah of tĕgal tjarik of patjarikan; in Tegal en Japara van s. of t. pantjèn. Eene andere wijze van aanduiding is het noemen van de soort van grond met bijvoeging van het ambt, waaraan het bezit is verbonden. Zoo spreekt men in Bantam, waar het dorpshoofd djaro heet, van s. of t. kĕdjaroan, in Cheribon, waar diens titel koewoe is, van s. of t. pĕkoewon; elders weder van s. of t. pĕtinggèn, van pĕtinggi; op Madoera van s. of t. klèboenan, van klèboen (Mad. = kliwon Jav.). Soms ook worden beide wijzen van aanduiding gecombineerd, bv. bĕngkok loerah, loenggoeh kamitoewå. In beperkten kring zijn ook nog hier en daar andere namen en uitdrukkingen

1 Zie Ind. Stbl. 1883 No 242 en 1885 No 144.

2 Voor de toestanden in Britsch Indië, zie Maine, t. a. p., p. 126. Waar het communaal bezit bestaat, vormen gemeenten zonder ambtelijk landbezit eene uitzondering. Daarentegen heeft men in Krawang en de Preanger-Regentschappen slechts zeer weinige gemeenten met ambtelijk landbezit; in Bantam bestaat het nog niet in de helft der gemeenten, en in Besoeki nog niet in een derde. Madoera is de eenige residentie met uitsluitend individueel bezit, war het ambtelijk landbezit algemeen is. Het ontbreekt er in slechts 7 gemeenten. Vergl. Kol. Verslag van 1893, Bijl. U. 
in zwang ${ }^{1}$. De gronden, krachtens het ambt bezeten, bestaan meerendeels uit sawah's, minder uit tĕgal's, tuinen, boomgaarden of vischvijvers, en eene enkele maal slechts uit een woonerf. De hoegrootheid dier gronden is, of eens voor altijd vastgesteld, of zij wordt, bij elke nieuwe verkiezing van een titularis, opnieuw bepaald. Men heeft verder, of vaste, voor het ambt bestemde gronden, of verwisseling, welke verwisseling wederom periodiek of niet-periodiek kan plaats hebben. De verwisseling komt alleen voor in gemeenten met communaal bezit, ofschoon ook in velen daarvan voor de ambtsvelden vaste plekken zijn bestemd. Bij communaal bezit wordt eindelijk de hoegrootheid van de ambtsvelden bepaald, of in een zeker aantal bouws, of in een zeker aantal gewone aandeelen, of in een evenredig deel van de totale vitgestrektheid van den gemeentegrond, meest 8 pCt. of 10 pCt. In gemeenten met louter individueel bezit heeft men natuurlijk alleen vaste ambtsvelden. Het bezit van ambtsvelden is onafhankelijk van dat der eigen gronden, in erfelijk individueel gebruiksrecht bezeten. Bij verlies van de betrekking gaat uit den aard der zaak het recht op de daaraan verbonden velden verloren. In de residentiën Tegal, Bagelen, Rembang en Madioen behoudt desniettegenstaande de afgetreden titularis, of zijn boedel, aanspraak op den te velde staanden oogst, dan wel, indien het veld reeds bewerkt is, gaat het bezit daarvan eerst na het loopende jaar, of na den loopenden moesson, over, dan wel eindelijk gaat het bezit terstond op den nieuwen titularis over, maar moet deze aan zijn voorganger of diens erfgenamen eene vergoeding geven voor hunne reeds aan den grond verrichten arbeid en hunne reeds gemaakte kosten ${ }^{2}$.

Omtrent de bestemming van gronden tot ambtsvelden en den omvang van het ambtelijk landbezit zijn sedert 1890 in geheel Java en Madoera gewestelijke regelingen tot stand gekomen, welke, met eerbiediging van verkregen rechten, paal en perk hebben gesteld aan de vroeger ten deze, vooral in streken met communaal bezit, voorkomende misbruiken. Zelfs individueel bezeten gronden schijnen vroeger niet zelden bij de ambtsvelden te zijn geannexeerd.

1 Vergl. Eindresumé, dl. I, p. 88 en v.

2 Vergl. een vonnis van den Landraad te Indramajoe dd. 10 April 1878 (Ind. Weekbl. v. h. R., Jaarg. 1879, № 850); Eindresumé, dl. I, p. 87 en v., 89 en v., $94,95,98,134$ en v., 174, 207 en v.; Kol. Verslag van 1893, Bijl. U. 
Bedoelde regelingen streven aan den anderen kant zooveel mogelijk naar eene billijke belooning voor de hoofden en bestuurders der gemeenten, en laten ook uitbreiding van het ambtelijk landbezit toe in gemeenten of streken, waar het niet of niet voldoende bestaat. De pĕlajangan-gronden kunnen dan daarvoor worden bestemd. Zoo is in de residentie Krawang nog in 1890 het ambtelijk landbezit ingevoerd ${ }^{\prime}$.

Het ambtelijk landbezit der dorpshoofden heeft aanmerkelijk grootere beteekenis dan dat der dorpsbestuurders. In vele streken hebben deze laatsten zelfs geen ambtelijk landbezit, d. w. z. in de gemeenten met communaal bezit erlangen zij, krachtens hun ambt, dus zonder daarvoor diensten te verrichten, een gewoon aandeel, en in gemeenten met zuiver individueel bezit, niets. Na het hoofd, zijn het diens adjuncten en de dorpsschrijvers, die in den regel het meest met ambtsvelden zijn begunstigd. In elk geval is, waar de dorpsbestuurders ambtelijk landbezit hebben, de grootte daarvan geringer dan die der ambtsvelden van het dorpshoofd, en verschilt zij naar het meerdere of mindere gewicht van hunne functies ${ }^{2}$.

Bij de beoordeeling van de waarde van het ambtelijk landbezit moet nog worden in aanmerking genomen, dat doorgaans de gemeenteleden de bewerking daarvan geheel of ten deele om niet op zich nemen, dan wel die bewerking tegen zeer geringe belooning verrichten. Zoo ook wordt de, voor de ambtsvelden verschuldigde, landrente vaak geheel of ten deele over de andere grondbezitters omgeslagen. Deze voordeelen intusschen worden door de leden van het dorpsbestuur in veel mindere mate genoten dan door het dorpshoofd. In de hierboven vermelde gewestelijke regelingen, sedert 1890 in het leven geroepen, is tevens voorgeschreven, dat, bij het optreden van nieuwe titularissen, deze voordeelen

1 Zie Kol. Verslag van 1891, p. 75; Eindresumé, dl. I, p. 91, dl. II, p. 315, 316, dl. III, p. 288 en vv. De tot stand gekomen gewestelijke regelingen maken een onderdeel uit van de gewestelijke regelingen betreffende de samenstelling der dorpsbesturen, gepubliceerd in de Koloniale Verslagen van 1891, Bijl. O, 1892, Bijl. Q, en 1893, Bijl. O. Eene korte opgave der daarin voorkomende bepalingen omtrent het ambtelijk landbezit vindt men op p. 302 en vv. van dl. III van het Eindresumé. Voor de bijzonderheden wordt naar deze bronnen verwezen. Zie ook, over de vroegere onzekerheid in de grenzen der ambtsvelden: Tijdschrift van het Binnenlandsch Bestuur, Jaarg. 1891-1892, p. 335 en vv.

2 Vergl. Eindresumé, dl. I, p. 94 en vv., dl. III, p. 288, 291. 
officieel moeten worden geconstateerd, en als door de bevolking vrijwillig op zich genomen lasten moeten worden aangemerkt ${ }^{1}$.

Behalve het ambtelijk landbezit van de hoofden en bestuurders der gemeenten, heeft men nog eenige andere gevallen van grondbezit, door personen krachtens eene zekere qualiteit genoten. Dit bezit, hetwelk men met den naam van quasi-ambtelijk zoude kunnen bestempelen, kan worden teruggebracht tot de volgende gevallen:

$1^{0}$ In sommige gemeenten met communaal bezit wordt een aandeel toegekend aan personen, die een bepaald beroep uitoefenen, waarvoor bijzondere geschiktheid noodig is, bv. aan een timmerman, een ḍalang, een g a mĕlan-speler, een politie-spion, een godsdienstleeraar, eene publieke danseres, enz., zonder dat bedoelde personen tot het dorpsbestuur behooren, of op grond van dienstpraestatie voor een aandeel in aanmerking komen ${ }^{2}$.

$2^{\circ}$ Hetzelfde geschiedt hier en daar met familieleden en volgelingen van dorpshoofden, ja zelfs met afgetreden hoofden en bestuurders ${ }^{3}$.

$3^{\circ} \mathrm{Op}$ Madoera bestaan nog bouwgronden bestemd voor de barissan of inlandsche militie. Bedoelde gronden worden door de commandanten dier troepen in aandeelen verdeeld, en aan de officieren, onderofficieren of minderen uitgegeven. Die aandeelen vormen een gedeelte der soldij. Bij ontslag uit den krijgsdienst of bij overlijden gaat het recht op het aandeel verloren. Bij de overname der Madoereesche vorstendommen is deze toestand gehandhaafd ${ }^{4}$.

$4^{\circ}$ In dezelfde residentie vindt men nog de zoogenaamıle nĕgĕrigrouden. Dit zijn de gronden', tijdens het vorstenbestuur aan leden der vorstelijke familie en aan grooten tot hun onderhoud uitgegeven. Wel zijn de houders, bij de overname der vorstendommen,

1 Zie p. 160 noot 1, en vergl. Eindresumé, dl. I, p. 94 en v., 96 en vv., dl. III, p. 387, 290 en v., 297; Sollewijn Gelpke, t. a. p., p. 43; Poensen, t. a. p., p. 101. Van de geheel of ten deele kostelooze bewerking der ambtsvelden spreekt reeds Raffles, t. a. p., p. 102.

2 Vergl. Eindresumé, dl. I, p. 99. Voor een analoog verschijnsel in BritschIndië, vergl. Maine, t. a. p., p. $125,126$.

s Vergl. Eindresumé, dl. I, p. 99.

4 Vergl. Eindresumé, dl. 1, p. 111, 137; Ind. Stbl. 1883 No 242 en 1885 No $1+4$. Bij de overname van Pamakassan is geene speciale bepaling voor de bariss a ngronden gemaakt; maar dit neemt niet weg, dat de oude toestand ook aldaar is gehandhaafd. Zie Ind. Stbl. 1858 No 54 en 1872 No 66 art. 1 litt. h. Voor de bestemming, aan de vrijvallende barissan-gronden te geven, zie noot $r$ van de tabel I der Bijl. Q van het Kol. Verslag van 1893.

6e Volgr. III. 
door het Gouvernement schadeloosgesteld in geld; maar de bewerkers dier gronden zijn voorloopig in hunne oude rechten gelaten ${ }^{1}$.

Vroeger kon men ook als soorten van quasi-ambtelijk landbezit aanmerken de sawah nĕgara in Bantam, de sawah tjarik in het Soemedangsche, en de sawah of tĕgal pikoelan in Probolinggo en Besoeki. Ofschoon nog in het Eindresumé besproken, zijn alle deze gronden thans in het erfelijk individueel bezit der opgezetenen ${ }^{2}$.

\section{\$ 12. BeZiT- OF GEBRUIKSRECHT OP DE BEgRAAFPLAATSEN, DE ERVEN DER MOSKEEËN EN DE ANDERE GEWIJDE GRONDEN.}

Begraafplaatsen zijn volgens de Moḥammedaansche wet altijd goederen in de doode hand (Arab waqf, Mal. Jav. Soend. wakap), niet alleen wanneer zij uitdrukkelijk in de doode hand zijn gebracht, maar ook van rechtswege door het enkele feit van het begraven. De eigendom daarvan behoort dus aan Allâh, en is aan het handelsverkeer onttrokken. Opgraven van lijken is alleen in bepaalde gevallen toegestaan, en nimmer kan de grond zelf aan zijne bestemming worden onttrokken. $\mathrm{Nu}$ treft men vooral in West-Java en op Madoera ook wel begraafplaatsen aan, die wak a p zijn, en worden elders ook de heilige, en vorstelijke begraafplaatsen gerekend in een bijzonderen, straks nader te beschrijven, rechtstoestand te verkeeren; maar met de gewone gemeentebegraafplaatsen is dit niet het geval. Laatstgenoemden worden namelijk geacht te behooren, of aan de betrekkingen der overledenen, of aan het Gouvernement, of aau niemand, of aan de gemeente, of aan hen die de graven hebben gedolven, in één woord, men vindt daarountrent de meest uiteenloopende begrippen. Ook zijn er voorbeelden van het veranderen der bestemming van den grond, waartoe alleen het houden van een offermaal noodig schijnt ${ }^{3}$.

Behalve de algemeene begraafplaatsen, aangelegd ingevolge het bepaalde bij Ind. Stbl. 1864 N" 196, welke nog betrekkelijk

1 Vergl. Kol. Verslag van 1893, Bijl. Q, tabel I, noot $r$.

2 Vergl. Kol. Verslag van 1888, Bijl. S, en de correctie in het Kol. Verslag van 1893, Bijl. Q, tabel I, noot $d$.

s Vergl. Minhâdj aț-Tâlibîn, dl. I, p. 225, 227, dl. 11, p. 189; Syed Ameer Ali: The law relating to gifts, etc. (Calcutta 1885), p. 243 en v., 339, 351 en v.; Eindresumé, dl. III, p. 160, 162 en v.; Soerjå Ngalam, p. 33. 
weinig talrijk zijn, en natuurlijk niet door het inlandsche recht worden beheerscht ${ }^{1}$, vindt men in den regel bij elke gemeente eene begraafplaats, met locaal uiteenloopende namen aangeduid, als pamakaman (van het Arab. maquam, lett.: "standplaats"), pakoeboeran (van het Arab. qoboer, meerv. v. qabr, d. i. "graf"), pasaréjan, astana, enz. Sommige gemeenten hebben meer dan ééne begraafplaats; terwijl omgekeerd ook wel meerdere gemeenten te zamen ééne begraafplaats bezitten, dan wel eenige gemeente hare dooden op de begraafplaats van eene andere brengt ${ }^{2}$. Behalve deze gemeentelijke heeft men nog particuliere begraafplaatsen, meestal op woonerven, waar echter ook aan anderen wordt toegestaan te begraven. Dikwijls vindt men op de gemeentelijke begraafplaatsen bepaalde, door muren of anderszins, afgescheiden plekken, welke de graven van bepaalde familiën bevatten, bv. van regenten of andere hoofden, van de stichters van het dorp, enz., welke graven eene zekere vereering genieten, zonder daarom nog als heilige graven (Mal. Jav. Soend. kramat, v. h. Arab. karâmah, d.i. "wonder“) te worden beschouwd. Het onderhouden en schoonmaken der graven van bijzondere personen is een plicht van hunne familie; het onderhouden en schoonmaken der gemeenschappelijke begraafplaats komt ten laste van de gemeente, welke daarmede eenige, meestal oude en van andere diensten vrijgestelde, personen belast, tegen vergoeding van een klein andeel in de gemeentevelden, van een deel der d jak a $t$ of der pitrah, enz. Bedoelde personen zijn veelal tevens belast met het delven der graven en andere werkzaamheden, op de bezorging van lijken betrekking hebbende, voor zooverre die niet ten laste der betrekkingen van de overledenen kunnen worden gebracht De boomen, op de gemeentelijke begraafplaats groeiende, blijven behooren aan hen, die ze geplant hebben, of die daarvan, tijdens de bestemming van den grond tot begraafplaats, eigenaars waren. Zijn dezen niet bekend, dan wel hebben zij van hun recht afstand gedaan, zoo volgen de boomen den rechtstoestand van den grond, en mogen niet door de leden der gemeente worden gekapt of geveld. Deze regel geldt ook ten aanzien van bamboe, op de begraafplaats groeiende. Over de boomen en de bainboe-stoelen waarvan hier sprake is, mag alleen ten algemeenen nutte door het dorpshoofd worden beschikt, speciaal

\footnotetext{
1 Die begraafplaatsen blijven dus hier verder buiten bespreking.

2 Van eene daarvoor te betalen recognitie vind ik geene melding gemaakt.
} 
tot vernieuwing van de benoodigdheden voor de begrafenissen of tot onderhoud der begraafplaats ${ }^{1}$.

Beschikking over grond, om die tot begraafplaats te maken, tegen den wil der rechthebbenden, schijnt zelfs vroeger zoo goed als niet te zijn voorgekomen, althans in het Eindresumé vindt men daarvan niets vermeld. Wel daarentegen schijnen niet zelden moskeeën gebouwd te zijn op gronden, aan de bezitters ontnomen ${ }^{2}$, in welk geval ten aanzien dezer gronden natuurlijk hetzelfde zal gelden, wat hierboven omtrent willekeurige beschikking over individueel bezeten grond tot andere doeleinden gezegd werd ${ }^{3}$. Intusschen zijn verreweg de meeste moskeeën met hare erven en de aan haar tot onderhoud, enz. verbonden bouwgronden, goederen in de doode hand, of worden althans door de bevolking als zoodanig beschouwd, in de gevallen, waarin men den oorsprong van den tegenwoordigen toestand niet meer kan nagaan ${ }^{4}$. De langgar's of bedehuizen, niet voor het Vrijdaggebed bestemd, zijn of eveneens in de doode hand, ò zij staan op gewonen dorpsgrond, en verkeeren dan in denzelfden rechtstoestand als de wegen, pleinen, enz. ${ }^{5}$.

1 Verg. Eindresumé, dl. III, p. 92, 160 en v., 345; L. Th. Mayer: De Javaan (Batavia 1894), p. 183 en vv. De in den tekst bedoelde gravenbewakers heeten zeer verschillend. Soms noemt men hen djo eroe-ko entji, d.w.z. "sleutelbewaarders"; maar dit woord is meer in gebruik voor de bewakers der graven van vorsten of heiligen. Op de meeste plaatsen heeten zij eenvoudig: „bewakers", en op enkele anderen: ahli majit (Arab. ahl al-majjit, d.w.z. „lijkenbezorgers"). Dat zij soms de djakat krijgen, is, blijkens mijne aanteekeningen, bij het onderzoek in 1867 en 1868 o. a. in het dorp Sidojoe van Bantam verklaard; doch in het Eindresumé, dl. 1ll, p. 338, wordt deze bijzonderheid niet vermeld.

2 Verg. Eindresumé, dl. III, p. 162, 163. Op laatstgeciteerde pagina staat zelfs, dat zulks "in den regel" heeft plaats gehad; doch dit is beslist onjuist, en alleen daardoor te verklaren, dat het onderzoek in 1867 en 1868 toevallig slechts in weinige gemeenten schijnt te zijn gehouden, waar zich moskeeën (mĕsigit d. w. z. een bedehuis voor het Vrijdaggebed) bevonden. Al had dus de willekeurige beschikking over den grond in de meerderheid van die gemeenten plaats gehad, zoo bewijst dit nog niets ten aanzien van den algemeenen toestand, Vergl. Mohammedaansche geestelijkheid, enz., p. 4, 5, 19, 20.

${ }^{3}$ Zie boven, p. 147, 148.

4 Vergl. Moḥammedaansche geestelijkheid, p. 37 en vv.; Eindresumé, dl. I, p. 100 en vv., 136, 209. Dat men in Midden-Java, behalve de erven der moskeeën, betrekkelijk zoo weinige goederen als eigenlijke wakap's vermeld vindt, ligt waarschijnlijk aan het feit, dat de opgezetenen er van ouds geene zakelijke bezitrechten op den grond uitoefenden, en dus ook geene wakap's konden maken. Zie boven p. 134 en vv., en Moḥ. geest., p. 39.

${ }^{5}$ Zie boven, p. 148. 
Als gewijde gronden van zeer bijzonderen, en buiten het Mohammedaansche recht staanden, aard, moeten echter de zoogenaamde "vrije" of pĕrdikan-dorpen in Midden-Java en op Madoera worden vermeld, waaronder men in het algemeen te verstaan heeft gemeenten, met hare gronden, geheel of ten deele van diensten aan den lande en van belastingen vrijgesteld, maar waarvan de bevolking daarentegen voor het onderhoud van graven, godsdienstscholen of voorname familiën moet zorgen.

Ofschoon de Europeesche administratie alle deze gemeenten met den naam van "perdikan" bestempelt, zoo bestaan daarvan toch verschillende categorieën, en moet men, naar de inlandsche begrippen, onderscheiden tusschen:

$1^{0}$ déså pĕrdikan ${ }^{1}$, of zoodanige gemeenten, welker gronden geschonken zijn aan bepaaid aangewezen personen met hunne nakomelingen, gewoonlijk onder voorwaarde van eene godsdienstschool te onderhouden en daarin als onderwijzer (goeroe) te fungeeren, dan wel van zorg te dragen voor de bewaking en het onderhoud van bepaalde graven. Soms zijn beide bedoelingen gecombineerd. De bevolking is dan, ten behoeve van den begunstigde, vrijgesteld van het opbrengen van belastingen en het praesteeren van diensten jegens den lande, en ook wat haar grondbezit betreft, staat zij niet rechtstreeks met den lande, maar met den begunstigde in rechtsbetrekking. De waardigheid van met zoodanig dorp begunstigd hoofd is, behoudens de voorwaarde van geschiktheid voor de waarneming zijner functies, erfelijk in zijn geslacht. Den begunstigden persoon noemt men: pĕrdika n, d. w. z. "vrijheer" ${ }^{2}$.

$2^{\circ}$ déså kapoetihan, of zoodanige gemeenten, waarvan de vrijstelling van, op den grond of op de ingezetenen rustende, lasten jegeus den lande, heeft plaats gehad ten behoeve, niet van een persoon, maar van eene instelling, waaraan geestelijken (w ong poetihan (N) of tijang pĕțakkan $(\mathrm{K}))^{3}$ verbonden zijn, bv. eene moskee of eene godsdienstschool. Onderhoud der personen in quaestie, maar geene individueele schenking van grond is dus hier het doel.

$3^{\circ}$ déså midjèn, of zoodanige gemeenten, waarvan de vrijstelling van, op den grond of op de ingezetenen rustende, lasten jegens

1 Of ook pardikan.

2 Voor de afleiding, zie het feestnummer van dit Tijdschrift, uitgegeven bij gelegenheid van het Orientalisten-Congres in 1883 , dl. II, p. 5 en vv.

s Vergl. Moh. geestelijkheid, p. 9. 
den lande, heeft plaats gehad ten behoeve van een bepaald persoon of eene bepaalde familie, welke daardoor aan het gezag der gewone inlandsche hoofden en ambtenaren werd onttrokken, en op zich zelf, d. w. z. rechtstreeks onder den vorst of, in het Gouvernementsgebied, onder den regent, staat. Is de gunst aan een bepaald persoon bewezen, zonder recht van overgang op zijne nakomelingen, zoo keert na diens dood het dorp in zijn vorigen rechtstoestand terug. Afstand van grond voor goed heeft bij deze dorpen dus niet plaats. De begunstigde is alleen belastingheffer.

$4^{\circ}$ déså pakoentjèn, of zoodanige gemeenten, waarvan de vrïstelling van, op den grond of op de ingezetenen rustende, lasten jegens den lande heeft plaats gehad, opdat de gemeente zich zoude belasten met de bewaking en het onderhoud van eene moskee of ander, voor den godsdienst bestemd, gebouw, of van eene heilige of vorstelijke begraafplaats. Ook in deze gemeenten had dus geene schenking van grond plaats, maar werden alleen speciale diensten en opbrengsten, tot instandhouding van het gebouw of de graven, aan de bevolking opgelegd. De personen, die in het dorp speciaal met de zorg voor een en ander zijn belast, heeten djoeroe-koentji, of alleen koentji, d. w. z. "sleutelbewaarders" 1.

Dat alle deze soorten van stichtingen alleen mogelijk waren van overheidswege, en niet door particulieren konden worden in het leven geroepen, behoeft geen betoog, en evenmin dat zij slechts konden worden in het leven geroepen door vorsten, wier eigendomsrecht op den grond niet door zakelijke bezitrechten der opgezetenen was beperkt ${ }^{2}$.

Ofschoon onderscheidene dezer stichtingen uit het Hindoetijdperk dagteekenen, zoo valt toch de oorsprong van de meesten in den Mohammedaanschen tijd, ja zelfs is die van eene enkele in een bevel van de Europeesche overheid te zoeken. Alle stichtingen uit het Hindoe-tijdperk zijn trouwens door de latere Mohammedaansche regeerders van Java en Madoera herhaaldelijk vernieuwd, en zoowel bij de overname der zoogenaamde MontjoNĕgaransche landschappen, als bij de invoering van het recht-

1 Vergelijk: Mohammedaansche geestelijkheid, p. 40, 41, gecorrigeerd naar F. Fokkens: Vrije desa's op Java en Madoera, in het Tijdschrift voor Indische Taal-, Land- en Volkenkunde, dl. XXXI (1886), p. 477 en vv.

2 Zie boven, p. 136. 
streeksche bestuur op het eiland Madoera heeft het Gouvernement verklaard de "vrije" dorpen in hunnen rechtstoestand te willen laten. Zelfs schijnt het, dat men, om staatkundige redenen, vaak te weinig streng is geweest in het beoordeelen van de aanvragen om als "vrij" dorp te worden erkend. In de meeste "vrije" dorpen vindt men thans nog archaïstische vormen van grondbezit, welke alleen door vergelijking met de toestanden onder het vorstenbestuur te verklaren zijn. Zoo bestaat in de dorpen, welke te zamen het Makam-gebied (Res. Banjoemas, afd. Poerbolinggo) vormen, nog het toempang paroek, d.w. z. de toestand dat de gronden dier verschillende gemeenten tusschen en door elkander verspreid liggen, iets dat men vroeger algemeen in de Montjo-Nĕgaransche landschappen, en thans nog bij zeer vele apanages in de Vorstenlanden aantreft. In de eigenlijk gezegde pĕrdi k a n-dorpen beschouwt het hoofd zich als eenig zakelijk rechthebbende op den grond, en is het recht der opgezetenen tegenover hem slechts contractueel, welk contractueel recht zich wederom voordoet, zoowel in den individueelen vorm, als in dien van communaal bezit met aandeelen ${ }^{1}$.

Het bovenstaande betreft alleen in zijn vollen omvang de dorpen, die in hun geheel zijn vrijgesteld; slechts tot op zekere hoogte is het toepasselijk op die, waar de vrijstelling niet op de geheele gemeente, maar op bepaalde gronden, dan wel op een bepaald getal hoofden van huisgezinnen betrekking heeft. In dit geval is het doel der vrijstelling altijd het bewaken en onderhouden van graven of moskeeën, zoodat deze gedeeltelijk vrijgestelde gemeenten slechts pĕrdikan- of pak o e n tjè n-dorpen kunnen zijn ${ }^{2}$. De verplichtingen, welke tegenover de vrijstelling staan, hebben in zoodanig geval uitsluitend

1 Vergl. Eigendomsrecht van den staat, p. 10 en vv.; C. J. Hasselman: De perdikan-dessas in het distrikt Tjahijana, in het Tijdschrift voor het Binnenlandsch Bestuur, Jaarg. 1887-1888, p. 72 en vv.; Fokkens, t. a. p., p. 486 en vv., 498 en vv., 501 en vv.; Eindresumé, dl. I, p. 103 en vv., dl. II, p. 121, en Bijl. p. 54 , dl. III, p. 22 en vv., 130 en v. Voor de bijzonderheden omtrent elk dorp of elke streek afzonderlijk wordt naar de opstellen van de heeren Fokkens en Hasselman verwezen. De beschrijving van het bestuur der "vrije" dorpen behoort natuurlijk niet te dezer plaatse.

2 Pĕrdikan's behoort men de vrijgestelde personen alleen te noemen, wannecr bepaald aan hen of aan hunne voorzaten bepaalde stukken grond zijn geschonken onder de bewuste voorwaarden. Van koentji's of djoeroe-koentji's kan men ook spreken, wanneer dit niet het geval is, en aan de gemeente slechts de last is opgelegd een zeker getal personen voor de diensten in quaestie beschikbaar te stellen. Dit volgt ten minste uit de hierboven van den heer Fokkens overgenomen definities; maar ik betwijfel, of het spraakgebruik wel altijd constant is. 
betrekking op de ingezetenen, in wier bezit zich de bewuste gronden bevinden, of op hen, die zijn vrijgesteld van heerendiensten als anderszins. Laatstgenoemden zullen, bv. bij communaal bezit, recht hebben op een aandeel, al behooren zij niet tot de volle dienstplichtigen; terwijl, bij individueel bezit, voor de vrijgestelde gronden evenmin diensten behoeven te worden gepraesteerd of landrente betaald. Overigens wijken in de gedeeltelijk vrijgestelde dorpen de toestanden, ook ten aanzien van het grondbezit, niet af van die der gewone omliggende gemeenten '.

\section{§ 13. DE RECHTEN, DOOR ' E INLANDSCHE BEVOLKING UITGEOEFEND} OP DEN GROND, BEHOORENDE TOT DE ZOOGENAAMDE PARTICULIERE

\section{LANDERIJEN EN DE ERFPACHTSPERCEELEN.}

Hierboven ${ }^{2}$ werd reeds aangetoond, dat, en in hoeverre, inlanders, die Europeesche zakelijke rechten op den grond uitoefenen, te dien aanzien aan de voor Europeanen geldende bepalingen zijn onderworpen. Wij hebben hier slechts in het kort te spreken van de rechten der bevolking, op zoodanigen grond gevestigd, waarbij wij ons echter tot enkele hoofdpunten kunnen bepalen met het oog op de omstandigheid, dat bedoelde rechten grootendeels niet door inlandsehe instellingen, maar door, van het Furopeesch gezag nitgegane, verordeningen worden beheerscht. Wat de perceelen betreft, in erfpacht nitgegeven ${ }^{3}$, de bevolking, daarop gevestigd, oefent op den door haar geoccupeerden, zelfs op den door haar voor eigen gebruik ontgonnen bouwgrond, geene zakelijke rechten uit, maar heeft alleen contractueele aanspraken tegenover den landheer. Dit zelfde is het geval met de bevolking, gevestigd op de zoogenaamde particuliere landerijen beoosten de rivier Tji Manoek 4. Deze contractueele rechten worden beheerscht door de gewone beginselen, welke voor de verbintenissen gelden

Daarentegen oefent, volgens art. 3 van Ind. Stbl. 1836 No $^{3} 9$, de inlandsche bevolking der particuliere landerijen bewesten de rivier Tji Manoek op alle gronden, door haar metterdaad be-

1 Vergl. Moḥammedaansche geestelijkheid, p. 42.

2 Zie pag. 86 en 87.

3 Voor zooverre die nog bestaan, geldt hetzelfde van de bevolking, gevestigd op, van het Gouvernement gehuurde, gronden. De perceelen, in gewoon eigendom of in opstal uitgegeven, zijn van te geringe uitgestrektheid, dan dat daarop van eene gevestigde lnlandsche bevolking sprake zoude kunnen zijn.

4 Vergi. Van Dissel, t. a. p., p. 293 en vv., en lnd. Stbl. 1880 No 150. 
bouwd, bewerkt of onderhouden, voor eigen rekening en risico, een zakelijk recht uit, door den wetgever "erfpacht" genoemd, omdat het met ouze erfpacht wel eenige analogie heeft, -maar dat inderdaad een specifiek inlandsch recht is, in natuur overeenkomende met het erfelijke bezits- of gebruiksrecht van het Mohamınedaansche recht en van de Agrarische Wet ${ }^{1}$. Het is een $\mathrm{jus}$ in re aliena, dat

1 Vergl. De Louter, t. a. p., p. 600; arresten van het Hooggerechtshof dd. 18 Jan. 1872 en 5 Maart 1874 (Ind. Weekbl. v. h. Recht, Nos 454 en 563). $1 \mathrm{k}$ geloof niet, dat door juristen deze opvatting meer bestreden wordt, en evenmin dat men in jure constituto de verbindende kracht van lnd. Stbl. 1836 No 19 meer kan bestrijden. Het beweren van den heer J. Faes, dat in de overschrijvingsacten der particuliere landerijen, sedert 1336 verleden, van de beperkingen van bedoeld Staatsblad geene melding werd gemaakt, en dat dus bij die acten "vol en vrij eigendom werd overgedragen", is mij niet duidelijk. Vergl. Geschiedenis van het particulier landbezit in West-Java, (Batavia 1893), p. II. Waar immers de wetgever het eigendomsrecht heeft beperkt, is de vraag of door den eigenaar, bij overdracht, van zoodanige beperking melding wordt gemaakt, niet ter zake meer dienende. Vergl. art. 570 lnd. Burgerl. Wb. $=$ art. 625 Ned. B. W. Ten allen overvloede heeft art. $62+$ lnd. B. W. de beperking van het eigendomsrecht der landheeren, door het zakelijke recht der opgezetenen, nog gesanctionneerd. Eene andere vraag is natuurlijk, of de wetgever niet onbillijk heeft gehandeld, en den eigendom der landheeren eigenmachtig heeft beperkt, door aan de inlandsche bevolking een vroeger niet bestaand zakelijk gebruiksrecht toe te kennen. Deze vraag wordt ontkennend beantwoord door wijlen Mr. H. C. Pennink: Het Reglement van 28 Februari 1836 voor de particuliere landerijen (Groningen 1885), p. 40, en door mij, in mijn meer geciteerd opstel over het eigendomsrecht van den staat, enz., p. 19, doch door anderen, waaronder ik den heer Faes als de meest gezaghebbende reken, in bevestigenden zin. Naar aanleiding van zijn uit al tegen mij, op p. XVII ran zijn even geciteerd belangrijk geschrift, wensch ik dien kundigen oud-resident beleefd het volgende te doen opmerken. Tegen den hoeksteen van mijn betoog, dat in West-Java, onder den invloed van den Islâm, zich bij de bevolking het hewustzijn van een zakelijk gebruiksrecht op den grond heeft ontwikkeld, wordt door hem niets aangevoerd, ja zelfs toont hij, op p. 269, door van Padjadjaran te spreken, d. w. z. van den Hindoe-tijd, de beteekenis van mijn betoog niet te hebben ingezien. $\mathrm{Nu}$ ontbreekt tot dusverre alle aanwijzing, dat, in dit opzicht, in het gebied der O. I. Compagnie bij de bevolking een ander rechtsbewustzijn bestond dan in de overige gedeelten van West-Java, ja wat meer zegt het Eindresumé leert ons dat, althans in de Preanger en in Krawang, de begrippen in hoofdzaak met die in Bantam, wat dit punt betreft, overeenstemmen. Dit nu vaststaande, kon de O. I. Compagnie, als getreden in de plaats der vroegere vorsten, door landverkoop geene andere of meerdere rechten overdragen dan die vorsten bezaten, en zij dus zelf bezat. Ook zonder eenig voorbehoud bij de vervreemding, kon die handeling naar algemeene rechtsbeginselen aan de rechten der bevolking niet schaden. Dit laatste slaat natuurlijk alleen op de gronden, waarop door de autochtone of geïmmigreerde bevolking zakelijke gebruiksrechten werden uitgeoefend, maar niet op onbebouwden of door eene vlottende bevolking bewoonden grond, gelijk de groote meerderheid der door de O. I. Compagnie vervreemde perceelen waren. Alle 


\section{tegen den landeigenaar kan worden gehandhaafd, dat vatbaar is voor vervreemding, verpanding, verhuur of erflating, alles be-}

stukken, op laatstbedoelde perceelen betrekking hebbende, en waarop men zich ten betooge van onvoorwaardelijken afstand beroept, zijn derhalve niet ter zake dienende. Evenmin valt tegen mijn beweren iets af te leiden, uit het gebruik, in de acten van verkoop, van de uitdrukking: "volle eigendom"; vooreerst omdat ik niet gezegd heb, dat het voorbehoud van de rechten der inlandsche bevolking in de "acten" heeft plaats gehad, maar ik, blijkens mijn citaat (p. 19 n. 5), integendeel op de aan die acten voorafgegane stukken doelde; in de tweede plaats omdat, naar het Oud-Hollandsch, evenals naar het hedendaagsche recht, bedoelde uitdrukking geenszins wettelijke en voor alle eigenaars geldende beperkingen van den eigendom, in eene bepaalde streek, uitsluit. Wil de heer Faes de onjuistheid van de geïncrimineerde plaats aantoonen, zoo heeft hij het omgekeerde daarvan te bewijzen, namelijk dat uit de stukken - niet alleen uit de acten van overdracht - op den verkoop van een bepaald land door de O. I. Compagnie betrekking hebbende, blijkt van eene gevestigde bevolking op dat land, en desniettegenstaande daarin geene reserve ten aanzien van de gebruiksrechten dier bevolking werd gemaakt. Levert hij dat bewijs, zoo moet mijne uitspraak, door invoeging van de woorden: „in den regel”, of iets dergelijks, worden verzacht. Zij blijft dan immers nog in haar geheel ten aanzien van den afstand van het land Klappa Noengal en de beide andere tegelijk vervreemde landerijen, gelijk mede ten aanzien van den primitieven afstand van het land Buitenzorg. Door dit laatste blijkt tevens, dat de uitspraak ook van kracht blijft ten aanzien van de verschillende landerijen, uit de latere splitsing van Buitenzorg voortgekomen. Vergl. Faes, t. a. p., p. XVIII; Eigendomsrecht, p. 19; Bijdragen, N. R. dl. VII (1864), p. 256; Plakaatboek, dl. V, p. 255, dl. VI, p. 58, 59. Dat desniettegenstaande ook in de acten van overdracht van bedoelde landen door de O. I. Compagnie van "vollen en vrijen eigendom" gesproken wordt, bewijst op nieuw, dat uit dien rechtsterm voor het onderwerp in quaestie niets valt af te leiden. In het voorbijgaan wijs ik er nog op, dat, in de bekende publicatie van Daendels dd. 13 Maart 1809, wel aan de landheeren wordt toegestaan van hunne opgezetenen hoogere opbrengsten, dan vroeger geoorloofd waren, te „bedingen", maar geenszins hoogere opbrengsten eigenmachtig te vorderen, en nog veel minder om naar willekeur over den grond te beschikken, waarop bedoelde opgezetenen zakelijke rechten uitoefenden; terwijl in $\S 4$ van de verkoopvoorwaarden van Raffles uitdrukkelijk "de wetten en gevestigde gebruiken des lands", omtrent de verhouding van den landheer tot zijne opgezetenen, werden gehandhaafd. Ten slotte moet ik onder de aandacht van den heer Faes brengen, dat niets mij aangenamer is, dan dat hij of anderen mijn arbeid aanvullen of verbeteren, dan wel mij, door hunne opmerkingen, aanleiding geven mijne meening omtrent eenig punt nader toe te lichten. Wenscht hij echter, dat $i k$ hem in den vervolge op wetenschappelijk gebied te woord sta, zoo verzoek ik hem vriendelijk zich ten mijnen aanzien van uitdrukkingen als: "verwarring stichtend geschrijf", "naschrijven van onjuiste stellingen uit eene dissertatie", enz. te willen onthouden. Het is toch mijne vaste gewoonte van op bedenkingen, in zoodanigen toon gesteld, niet in openbare geschriften te antwoorden, en $\mathrm{ik}$ heb op dien regel alleen ditmaal eene uitzondering gemaakt, omdat de heer Faes zijn stuk ook bij de Regeering schijnt te hebben ingediend, blijkens de onderteekening in de qualiteit van lid eener officieele commissie. 
houdens nakoming der wettelijk geregelde verplichtingen en voorwaarden. Daar alle woeste gronden, tot bedoelde particuliere landerijen behoorende, vrij eigendom zijn van den landheer, kan de inlander zich daarop geen erfpachtsrecht verwerven door ontginning, tenzij met diens toestemming ${ }^{1}$; doch overigens wordt het erfpachtsrecht beheerscht door de plaatselijke instellingen en gebruiken ${ }^{2}$, en zullen daarbij ex analogia de, elders ten aanzien van het erfelijk individueele gebruiksrecht bestaande, instellingen en gebruiken mutatis mutandis als richtsnoer kunnen gelden. Alleen moet als eene algemeene afwijking worden gewezen op het ontbreken van inlandsche gemeenten op bedoelde landerijen. Daardoor vervallen van zelve alle beperkingen in de uitoefening van, en de beschikking over, het recht, in andere streken uit gemeentelijke regelingen voortspruitende evenals het communaal grondbezit. Gewijde gronden, in een bijzonderen rechtstoestand verkeerende, bestaan op bedoelde particuliere landerijen niet; wel daarentegen ambtelijk landbezit, zoowel voor dorps- als voor distriktshoofden, gelijk mede een weiderecht en een recht om boschprodukten te verzamelen ${ }^{3}$. De vraag, of het inlandsche erfpachtsrecht vatbaar is voor overdracht aan Europeanen of Vreemde Oosterlingen, wordt in verschillenden zin beantwoord ${ }^{4}$.

1 Vergl. artt. $2-7,19-21,23$ van lnd. Stbl. 1836 No 19. De wijzen van overgang, in art. 4 genoemd, moeten als enuntiatief en niet als limitatief worden beschouwd. Deze opvatting is, meen ik, nooit bestreden.

2 Eene beschrijving van die instellingen en gebruiken is mij niet bekend. Voor de wettelijk geregelde verplichtingen en voorwaarden meen ik te kunnen verwijzen naar De Louter, t. a. p., p. 599 en vv.

3 Vergl. artt. 2 al. 2, 52 en 53 van lnd. Stbl. 1836 No 19.

4 In ontkennenden zin wordt de vraag o. a. beantwoord in de arresten van het Hooggerechtshof dd. 24 April en 28 November 1878 en 27 Februari 1879 (Tijdschrift: Het Recht in N. I., dl. XXX (1878), p. 142 en vv., dl. XXXI (1878), p. 378 en vv., en dl. XXXII (1879), p. 313 en vv.), gelijk mede door Pennink, t. a. p., p. 43 en vv., en door mij in de Handelingen der N. I. Juristenvereeniging, Jaargang 1887 , dl. I, p. 27 en vv. In bevestigenden zir luiden o. a. de arresten van het Hooggerechtshof dd. 24 December 1874, 15 October 1885 en 22 September 1892 (Ibid. Nos 604, 1169 en 1532), en spraken zich uit Mr. J. Sibenius Trip, Ibid. dl. XXX (1878), p. 97 en vv., dl. XXXII (1879), p. 8 en vv.; De Louter, t. a. p., p. 601 . Het door mij t. a. p. aangevoerde argument, dat Europeanen en aan het Europeesche recht onderworpen Vreemde Oosterlingen, naar algemeene beginselen, onmogelijk een zakelijk recht kunnen uitoefenen, in hunne wetgeving onbekend, werd tot dusverre door de tegenstanders niet wederlegd. Al kan men dus, gelijk het Hooggerechtshof nog in laatstgenoemd arrest doet, aantoonen dat de wetgever in 1836 bedoeld heeft, ook Chineezen als opgezetenen met inlandsche erfpachtsrechten toe te laten, zoo is toch de zaak anders geworden 
Naast de zakelijke rechten van den inlander op den groud, behoorende tot de hier besproken particuliere landerijen, kan hij op dien grond ook contractueele rechten uitoefenen. Ten aanzien van deze contractueele rechten moet worden herhaald, wat zooeven werd opgemerkt met opzicht tot de contractueele rechten op den grond, door opgezetenen van de erfpachtslanden en van de particuliere landerijen beoosten de rivier Tji Manoek uitgeoefend ${ }^{1}$.

\section{§ 14. DE RECHTEN, DOOR DE INLANDSCHE BEVOLKING UITGEOEFEND OP DEN GROND IN DE VORSTENLANDEN.}

Hierboven werd reeds aangevoerd ${ }^{2}$, dat in de Vorstenlanden van Midden-Java de eigendom van den grond berust bij den vorst ${ }^{3}$, en niet beperkt is door eenig zakelijk gebruiksrecht van de opgezetenen. Alleen de terreinen, door den vorst aan het Gouvernement afgestaan voor forten en andere landsgebouwen, gelijk mede de gronden aan Europeanen en Vreemde Oosterlingen in eigendom afgestaan, zijn aan dezen algemeenen regel onttrokken; maar die gronden worden, ook als zij naderhand aan inlanders worden overgedragen, beheerscht, niet door de godsdienstige wetten, volksinstellingen en gebruiken, doch door het Indische_Burgerlijk Wetboek. Zij blijven dus hier verder buiten sprake. Zoo ook vormen eene uitzondering op den regel de gronden, in de doode hand gebracht, en die der zoogenaamde "vrije" dorpen, welke gronden in rechtstoestand niet verschillen met de gelijksoortige gronden buiten de Vorstenlanden, en waaromtrent dus wordt verwezen naar de hierboven gegeven beschrijving van dien rechtstoestand ${ }^{4}$.

Van den overigen grond, voor zooverre die niet gebruikt is voor paleizen, lusthuizen en andere niet-productieve doeleinden,

door hunne onderwerping aan het Europeesche vermogensrecht bij lnd. Stbl. 1855 No 79. Dat' eindelijk de wetgever, door bij Ind. Stbl. 1875 No 179 het overdragen van erfelijk gebruiksrecht op domeingrond aan niet-lnlanders te verbieden, implicite deg overdracht van lnlandsche erfpachtsrechten toestond, is $\mathrm{m}$. i. eene minder juiste toepassing van den regel: qui de uno dicit, de altero negat. Zie boven, p. 100, 101; Familie- en erfrecht, p. 503.

1 Vergl. artt. 6 en 41 van lnd. Stbl. 1836 No 19, en zie boven, p. 168.

2 Zie boven p. 136.

$s$ Onverminderd natuurlijk de staatsrechtelijke verhouding van den vorst tot het Gouvernement als zijn leenheer.

4 Zie boven, p. 162 en vv.; Spaan, t. a. p., p. 14, 15, 21; Brooshooft, t. a. p., p. 2 ; Van Alphen, t. a. p., p. 292. 
trekt de vorst gedeeltelijk zelf de inkomsten, gedeeltelijk heeft hij dien in leen gegeven aan familieleden, ambtenaren, officieren, hofdignitarissen en bedienden. Dit ambtelijke landbezit heet in het Javaansch: loenggoeh (N) of lĕnggah (K) ${ }^{1}$, en wordt door de Europeesche administratie met den algemeenen naam van "apanage" aangeduid ${ }^{2}$. Daar de apanagehouders in den regel, wegens de plichten van hun ambt of hunne bediening, den grond niet zelf kunnen administreeren, geschiedt de exploitatie door middel van běkĕl's of pachters, over wie reeds vroeger het noodige is gezegd ${ }^{3}$. Ook de vorst verpacht op dezelfde wijze den grond, welke niet voor speciale doeleinden is gereserveerd.

In de residentie Soerakarta zijn in den regel voor elk ambt of elke bediening speciale gronden als apanage bestemd, zoodat men, bij bevordering, het apanage, dat men bezit, aan zijn opvolger overgeeft, en op zijne beurt in bezit neemt het apanage, aan het hoogere ambt of aan de hoogere bediening verbonden. Ditzelfde geldt ook van de vaste apanages, verbonden aan bepaalde titels van 's vorsten naaste familieleden, welke titels altijd slechts door één persoon gevoerd kunnen worden, bv. van het apanage van den Pangéran $\mathrm{Ngabèhi.} \mathrm{In} \mathrm{de} \mathrm{residentie} \mathrm{Djokjakarta} \mathrm{daarentegen,}$ behoudt men bij bevordering het apanage, waaraan echter alsdan een stuk wordt toegevoegd in evenredigheid van de verhooging in den staats- of hofdienst. Naar beide systemen blijft intusschen de totale uitgestrektheid der apanages, waarvan hier sprake is, tamelijk standvastig. Alleen bij het scheppen van nieuwe, en het opheffen van bestaande ambten of bedieningen, ondergaat deze uitgestrektheid noemenswaardige wijziging. Anders is het intusschen gesteld met de overige apanages, op grond van familiebetrekking met den vorst genoten. Van deze apanages namelijk heeft ook in Soerakarta geene verwisseling plaats. Daar zij echter geëvenredigd behooren te zijn aan de rangen, welke de personen in quaestie in den adel innemen, en bedoelde rangen verminderen, naarmate er meerdere generaties staan tusschen den begunstigde en zijn vorstelijken stamvader,

1 Ook paloenggoehan (N) of palěnggahan (K).

2 Alleen in het Mangkoe-Nẽgaransche gebied zijn de apanages langzamerhand zeer ingekrompen, en worden tegenwoordig verreweg de meeste ambten en bedieningen uitsluitend in geld bezoldigd. Vergl. Spaan, t. a. p., p. 29, 30; Brooshooft, t. a. p., p. 39.

3 Zie boven, p. 115 en vv. Ook de Europeesche landhuurders zijn, naar de Javaansche begrippen, běkěl's. Vergl. Anggĕr Sadåså, art. 19. 
zoo heeft in elke familie eene voortdurende inkrimping van apanage plaats, en worden telkens, uit de aldus vrijvallende stukken, nieuwe apanages gevormd ten behoeve van de nieuwe gerechtigden, welke bij vermeerdering der vorstelijke nakomelingen ontstaan ${ }^{1}$. De vrijvallende stukken komen weder bij de gronden, van welke de vorst zelf de inkomsten trekt, gelijk omgekeerd ook uit die gronden in de behoefte aan nieuwe apanages wordt voorzien; wanneer de vrijvallende stukken vau bestaande apanages daartoe niet voldoende zijn. Tengevolge van deze eu andere oorzaken vormen zeer vele apanages geen aaneengeschakeld en afgerond geheel; maar liggen de daartoe behoorende gronden tusschen en door elkander verspreid. Men noemt dezen, vroeger ook ten aanzien van de grenzen der vorstendommen zelve bestaan hebbenden, toestand: toempang paroek. Het apanage op grond van familiebetrekking tot den vorst wordt casu quo genoten nevens dat, hetwelk verbonden is aan een ambt of eene bediening ${ }^{2}$.

Welke rechten de apanagehouder op den grond en op de daarop gevestigde bevolking heeft, werd reeds vroeger vermeld, en zoo ook dat, en in welke mate, door hem of door den Vorst die rechten op den pachter (b ěk ěl) worden overgedragen ${ }^{3}$. De apanagehouder is echter, ook als hij niet tot verpachting wil overgaan, verplicht een administrateur (b ěkěl maron) of een opzichter (bĕkĕl ngiras) aan te stellen voor zijn grond 4. Het gevolg daarvan is, dat de koeli's, d.w. z. de opgezetenen die noch bĕkĕl noch apanagehouders zijn, op den groud slechts kunnen verblijven krachtens overeenkoinst, hetzij met den apanagehouder, hetzij met den bĕkĕl aangegaan, al naarmate het perceel niet of wel verparhht is. De door deu koeli te bedingen voorwaarden hangen geheel af van de verhouding tusschen vraag en aanbod. Die voorwaarden kunnen evenwel worden teruggebracht tot de vier volgende stelsels van exploitatie van den grond:

$1^{\circ}$ het b ĕn g k ok- of grondgebruik-stelsel, daarin bestaande, dat

1 Vergl., voor nadere toelichting, mijne Inlandsche rangen en titels, p. 26 en vv., 79 en vv. In de $5^{\text {de }}$ generatie houdt het toekennen van apanage geheel op.

${ }^{2}$ Zie boven, p. 167, en vergl. Spaan, t. a. p., p. 15 en vv.; Brooshooft, t. a. p., p. 2, 3; Van Alphen, t. a. p., p. 293.

s Zie boven, p. 116. De grootte der apanages wordt, evenals die der bĕk él. schappen, berekend in djoeng's en tjatjah's. Zie boven, p. 115 noot 4. De gronden worden genoemd naar de daarop gelegen dorpen, of liever vestigingen.

4 Zie boven, p. 115, en Anggĕr Agĕng, art. 27; Pranatan Patoeh, art. 1. 
de apanagehouder of de bĕkĕl een gedeelte van den bouwgrond voor zich reserveert om dien zelf te bebouwen of te doen bebouwen; terwijl hij het overige in aandeelen verdeelt, welke aan de koeli's in gebruik worden gegeven tegen zekere opbrengsten, of tegen het verrichten van zekeren arbeid op het voor den apanagehouder of den bĕk ĕl gereserveerde gedeelte;

$2^{\circ}$ het maron- of halfbouw-stelsel, daarin bestaande, dat de bouwgrond bij kleine stukken aan de koeli's wordt verhuurd tegen uitkeering van een gedeelte van den oogst, naar de onderscheidingen ten aanzien van deze overeenkomst vroeger uiteengezet ${ }^{1}$;

$3^{\circ}$ het g lè bag g a n- of wisselbouw-stelsel, daarin bestaande dat aan de koeli's stukken bouwgrond worden afgestaan, waarvan zij een afgebakend gedeelte voor zich zelf, en het overige voor den ananagehouder of den bĕkěl béwerken, beplanten en oogsten, zoodanig dat periodiek de beide gedeelten omwisselen;

$4^{\circ}$ het gliḍik- of daglooner-stelsel, daarin bestaande, dat het perceel door den apanagehouder of den b ěkěl geheel voor eigen rekening en risico geëxploiteerd wordt met gehuurde arbeiders, die niet eens op den grond behoeven te wonen.

Intusschen zijn andere soorten van overeenkomsten niet uitgesloten, evenmin als modificaties van de hier kortelijk verklaarde, meest gewone stelsels. Alles hangt af van het vrij beding tusschen partijen. Bij aftreding van den bĕk ěl moet diens opvolger aan den koeli de gelegenheid geven onder zekere voorwaarden den grond te blijven bewerken ${ }^{2}$. Ook worden niet zelden in de pachtbrieven (piag ĕın) aan den bĕkĕl zekere verplichtingen tegenover zijne k o eli's opgelegd, ten einde volksverloop te voorkomen; maar dit alles neemt niet weg, dat het eenige, waarop de koeli eigendomsrecht uitoefent, is hetgeen hij op den grond gezaaid, geplant of gebouwd heeft, zonder dat echter aan bedoeld eigendomsrecht de bevoegdheid verbonden is om tevens den grond te blijven gebruiken. Zijn eigendomsrecht bepaalt zich, gelijk dat van een huurder bij ons, tot een recht van weghaling onder voorwaarde van den grond weder in den vorigen staat terug te brengen ${ }^{3}$. Voorts bevat de, in het apanage of in den pacht begrepen, grond zoowel de akkers als de woonerven. Wat men in de Vorstenlanden "dorpen" noemt, zijn, tegenwoordig

1 Zie boven, p. 112,113 . Bij de niet aan Europeanen verhuurde gronden is dit stelsel het meest gewone.

2 Vergl. Anggĕr Sadåså, art. 36; Pranatan Patoeh, art. 10.

s Vergl. art. 1567 Ind. Burgl. Wb. $=$ art. 1603 Ned. Burgl. Wb. 
althans, geene gemeenten, d. w. z. lichamen met rechtspersoonlijkheid en eigen bestuur, maar eenvoudig agglomeraties van woningen, onder een bepaalden naam bekend. Zoodanige agglomeratie kan tot één pachtperceel behooren, maar evengoed tot meerdere pachtperceelen. Tegenwoordig is dit laatste zelfs regel ${ }^{1}$. Behooren er bouwgronden bij, zoo wordt aan de personen, die bij de bewerking daarvan betrokken zijn, veelal tevens een stukje in het dorp aangewezen om te bewonen; doch de apanagehouder of de pachter is vrij om zooveel en zoo weinig personen in zijn dorp toe te laten, als hij wil, en zijn belang medebrengt. In de dorpen zonder bouwgronden (déså (N) of doesoen (K) k o pèk) bestaat de opbrengst in de diensten der inwoners, en in den huurprijs voor den grond, waarop de woningen geplaatst zijn, of in een aandeel in de vruchten of groenten, welke op de erven geteeld worden. Ook ten deze hangen de voorwaarden, door den koeli te bedingen, geheel af van vraag en aanbod ${ }^{2}$.

De ontginning van woesten grond doet in geen enkel opzicht te kort aan het eigendomsrecht van den vorst, noch aan de rechten van den apanagehouder of van den bĕkĕl. Hij, die woesten grond wil ontginnen, welke tot een apanage of tot een pachtperceel behoort, kan dit slechts doen met vergunning van den apanagehouder of van den bĕk ĕl, en deze kunnen hem dan de voorwaarden stellen, welke zij goedvinden. Ontginning van niet als apanage uitgegeven of niet verpachten woesten grond, staat in den regel vrij; maar men kan de ontginning alleen behouden, wanneer men die als apanage van den vorst verkrijgt, of als běkĕl van hem pacht. In overeenstemıning met deze beginselen geven de Javaansche wetten den ontginner wel bescherming tegenover stoornis, door derden gepleegd, doch niet tegenover den apanagehouder of den bĕkĕl van den grond, noch tegenover den vorst. Reclames van derden tegen nieuwe ontginningen verjaren na 3 jaar. Als grensteekenen van ontginningen mogen slechts merken van steen of groote boomen worden gebezigd ${ }^{3}$.

1 In dat geval liggen de woningen en erven, tot de verschillende perceelen behoorende, niet zelden ook door elkander verspreid.

2 Vergl. Spaan, t. a. p., p. 30 en vv., 39 en vv., 58 en vv.; Pranatan Patoeh, art. 5; Brooshooft, t. a. p., p. 3, 6, 7, 10 en v., 19 en vv.; Van Alphen, t. a. p., p. 283.

s Vergl. Anggĕr Sadås̊̊, art. 41, 42; Anggěr Goenoeng, art. 60; Spaan, t. a. p., p. 64 en vv. 
Ten slotte moet nog worden melding gemaakt van zekere gronden, welke in een bijzonderen rechtstoestand verkeeren, namelijk de zoogenoemde pangrĕmbé- en kĕparak-gronden. De pangrĕmbé-gronden vormen eeu deel van de terreinen. waarvan de vorst zelf de inkomsten trekt, maar zij worden nimmer in apanage uitgegeven, als zijnde bestemd voor de voorziening in de dagelijksche behoeften van de hofhouding. De b ěkĕl's, die perceelen van deze gronden gepacht hebben, brengen dan ook geene pacht in geld op, maar in vruchten, groenten en andere producten van den bodem, welke in den Kraton benoodigd zijn. De k ĕp a rak-gronden, vormen eene soort van erfelijke leenen ten behoeve van de zoogenaamde kĕparak's, d. z. de personen, die eene afdeeling van de lijfwacht van de Soesoehoenan of van den Sultan vormen, to e mbak irĕng of "Zwarte pieken" genaamd. Hoofden van de kĕparak's zijn de Boepati k ěparak tĕng ĕn en de Boepati kẹparak kiwå. Behalve den dienst als lijfwachten, zijn hun ook nog andere diensten opgedragen. Deze leenen gaan op de kinderen en verdere afstammelingen van de houders over, zelfs in de vrouwelijke linie; maar in het laatste geval moet de vrouw in quaestie een vervanger stellen. Bij het uitsterven van eene familie, of bij verlies van het leen wegens veroordeeling ter zake van een zwaar misdrijf, wordt dit aan een ander persoon toegewezen. Intusschen is de vorst steeds bevoegd ook om andere redenen over het leen of een gedeelte daarvan te beschikken. De oorsprong dezer leenen is onzeker; vermoedelijk waren de primitief daarmede begiftigden, personen, die zich voor de uitbreiding van den Islâm verdienstelijk hadden gemaakt ${ }^{1}$.

\section{§ 15. Irrigatierecht.}

De begrippen omtrent het irrigatierecht in West-Java zijn geene anderen dan die van den Islâm. Het water, dat zijn natuurlijken loop volgt, is hakoellah (v.h. Arab. ḥaqq.Allâh), d. w. z. het behoort aan Allâh, en ieder mag daarvan nemen zooveel hij wil en kan, mits eerbiedigende de rechten van derden op den door hen erfelijk individueel bezeten grond, indien het water zich daarop

1 Vergl. Spaan, t. a. p., p. 17, 20 en v.; Winter: Javaansche samenspraken, dl. I, p. 69; Inlandsche rangen en titels, p. 54, 57; Brooshooft, t. a. p., p. 3; Van Alphen, t. a. p., p. 290, 292 en vv.

6e Volgr. III. 
bevindt; terwijl het water door toeëigening privaat-eigendom (hakoeladam v. h. Arab. ḥ aqq a l-âda m î) wordt. Leidingen en andere waterwerken behooren aan de aanleggers, gelijk mede het daardoor verkregen water, en zijn, afgescheiden van den grond, voor het uitoefenen van zakelijke rechten vatbaar ${ }^{1}$. Alleen op de particuliere landerijen bewesten de rivier Tji Manoek is deze materie door de artt. 32 en 33 van Ind. Stbl. 1836 No 19 geheel aan het gezag der inlandsche instellingen en gebruiken onttrokken, en aan de verordeningen en bevelen van het Gouvernement onderworpen.

In de overige gedeelten van Java, gelijk mede op Madoera, treft men, blijkens het onderzoek in 1867 en 1868 gehouden, de meest onbestemde en uiteenloopende begrippen aan omtrent het irrigatierecht. Hier meent - men, dat het water principieel aan niemand toebehoort; elders beschouwt men iedereen als rechthebbende daarop, en in weder andere streken beschouwt men als eigenaar het Gouvernement, of wordt het water als een accessorium van den grond aangemerkt. Van eerbiediging der individueele rechten op leidingen en andere werken, en op het daardoor verkregen water, is over het algemeen in die streken dan ook geen sprake. Slechts in enkele gemeenten van Banjoemas, Bagelen, Japara en Rembaug vindt men erkenning van zoodanige individueele rechten, meest trouwens ten aanzien van onbeteekenende leidingen en werken; maar overal elders worden de persoonlijke aanspraken der aanleggers hoogstens zoo lang erkend, als zij leven, of de onmiddellijk op hen volgende rechtverkrijgenden bekend zijn. Bij verdere geslachten worden eenvoudig als rechthebbenden beschouwd allen, die feitelijk voor hunne sawah's het door die leidingen en werken verkregen water gebruiken, en deelnemen aan het onderhoud er van. Zonder dit laatste erkent men geen recht op het water hoegenaamd. De overgang van de rechten der aanleggers in die der gemeenschappelijke gebruikers en onderhouders heeft, in streken met communaal bezit, nog spoediger plaats, dan in die met zuiver individueel bezit. In eerstgenoemde streken wordt veelal zelfs aan de aanleggers slechts een tijdelijk recht toegekend, en brengt het feit van de toewijzing van een saw ah-aandeel, ja zelfs dat der ontginning van eene nieuwe

1 Vergl. Minhâdj aț-Tâlibîn, dl. II, p. 179 en vv.; Resumé van Bantam, p. 170 en v.; Eindresumé, dl. II, p. 331 , dl. III, p. 310 , 312. Alleen ingeval van behoefte aan drinkwater is men, volgens den Islâm, onder zekere omstandigheden verplicht het water, waarvan men eigenaar is, zonder vergoeding met een ander te deelen. Vergl. Fath al-Qaríb, p. 397, 399. 
sawah, van rechtswege toekenning van aanspraak op het water met zich, behoudens de voorwaarde van deelneming aan het onderhoud. Trouwens buiten West-Java schijnen de meeste leidingen en werken van belang te zijn aangelegd op hoog bevel, dan wel in gemeenschappelijken arbeid door één of meer gemeenten, niet zelden met willekeurige beschikking over individueel bezeten grond. Dat in zoodanig geval het recht op het water ook volgens den Islâm een gemeenschappelijk recht is, behoeft geen betoog. Alleen ligt het verschil tusschen de streken met zuiver individueel bezit, als West-Java en Madoera, aan den eenen kant, en de streken met communaal bezit aan den anderen kant, wat de op hoog bevel of gemeenschappelijk aangelegde leidingen en werken betreft, daarin, dat in eerstgenoemde streken het gemeenschappelijke recht op het water geene gevolgen heeft gehad ten aanzien van het grondbezit; terwijl bedoeld recht in laatstgenoemde streken het gemeenschappelijk bezit van den grond na zich sleepte ${ }^{1}$.

Als eene andere afwijking van de Moḥammedaansche wet moet, ook ten aanzien van West-Java, vermeld worden het bij die wet onbekende preferente recht van den aanlegger van eene waterleiding of een waterwerk om, onder bepaalde voorwaarden en beperkingen, ook den grond te ontginnen, welke met de leiding of het werk geïrrigeerd kan worden. Alleen op Madoera en in Madioen, Kediri en verder oostwaarts gelegen residentiën schijnt dit recht van voorkeur onbekend ${ }^{2}$.

De behoorlijke en regelmatige verdeeling van het irrigatie-water heeft, ingeval alle rechthebbende saw a h's niet te gelijk voldoende kunnen worden voorzien, een aantal rechten en verplichtingen doen ontstaan, welke tot de navolgende categorieën kunnen worden teruggebracht Men heeft vooreerst het stelsel van prioriteit der hooger gelegen saw ah's of sawah-blokken, zonder dat daarbij wederom melding wordt gemaakt van de bepaling van den Islâm, dat het prioriteitsrecht ophoudt, zoodra het veld ter hoogte van de enkels onder water staat ${ }^{3}$. Een ander stelsel is dat van beurtregeling, zoodat elk veld of elk blok van velden het water bekomt om het etmaal,

1 Vergl. Eindresumé, dl. II, p. 330, dl. III, p. 310 en vv., en zie boven, p. 151, 152. Het verband van het gemeentewezen met het irrigatierecht bestaat ook in BritschIndië. Vergl. Maine, t. a. p., p. 108 en vv. Daarentegen erkent wederom art. 43 der Koeţ. Mân. in zeer beslisten vorm de individueele rechten ten aanzien van het irrigatiewezen.

2 Vergl. Eindresumé, dl. II, 329 en v.

s Vergl. Minhadj aț-Tâlibîn, dl. II, p. 180 . 
dan wel om de $2,3,4$ tot zelfs 8 dagen; terwijl in hetzelfde blok soms het eene veld het water des daags bekomt, en het andere des nachts. Een derde stelsel betreft de verhouding tusschen de sawah's of sawah-blokken, welke onmiddellijk hun water uit de leiding erlangen, en die welke daarachter of daar beneden liggen. Op de bezitters van eerstbedoelde gronden rust dan in den regel de verplichting om het water op de laatstbedoelden te laten afvloeien, nadat zij zelf voldoende voorzien zijn; terwijl wederkeerig voor laatstbedoelde gronden meestal de verplichting bestaat het afloopende water te ontvangen. Op dezen laatsten regel schïnt alleen eene uitzondering te worden aangenomen, indien de lagere gronden het water in het geheel niet kunnen gebruiken. Dan moeten de bezitters van de hooger gelegen sawah's het water te hunnen koste elders doen afvoeren. Niet zelden worden ook de achtergelegen sawah's, door bijzondere kleine leidingen of kokers, rechtstreeks uit de hoofdleiding van het benoodigde water voorzien ${ }^{1}$.

De hierbedoelde regelingen van het watergebruik ondergaan naar plaatselijke omstandigheden vele modificaties. Onderlinge schikkingen tusschen de rechthebbenden hebben overal plaats, welke schikkingen intusschen in West-Java steeds verbaud houden met de individueele rechten, aldaar op leidingen en werken uitgeoefend. In vele gemeenten treedt bij beurten één der rechthebbenden op het water als bestuurder op. Overigens staat de waterregeling in de streken, waar de individueele rechten der aanleggers niet voortdurend erkend worden, en in de streken waar dit wel het geval is, zoodra rechten van derden daarbij zijn betrokken, onder het toezicht en de bevelen der gemeentebesturen, naar de omstandigheden met inachtneming der bevelen van hoogere autoriteiten. Bij leidingen en werken, welke aan de gemeente zelve toebehooren, is de geheele zaak handen van het gemeentebestuur, onder hetzelfde voorbehoud. Dikwijls is een speciaal dorpsbestuurder met deze aangelegeńheid belast; anders behoort zij tot de persoonlijke attributen van het dorpshoofd, en soms van den dorpsgeestelijke ${ }^{2}$.

De waterleidingen en werken, welke onder rechtstreeksch beheer van het Gouvernement staan, en waarvoor speciale ambtenaren zijn aangesteld, blijven hier buiten beschouwing, als zijnde de

1 Vergl. Eindresumé, dl. III, p. 316 en vv.

2 Vergl. Ibid. p. 258 en vv., 314,320 en vv. 
inlandsche rechtsbegrippen daarop niet toepasselijk. Daar deze aangelegenheid nimmer in wettelijken vorm geregeld is, en geheel door administratieve voorschriften en bevelen wordt beheerscht, zoude zij ook om die reden in dit, aan het privaatrecht gewijde, opstel niet op hare plaats zijn ${ }^{1}$.

Wat ten slotte de Vorstenlanden betreft, zoo gelden omtrent het graven van waterleidingen en den aanleg van waterwerken dezelfde beginselen, als ten aanzien van het ontginningsrecht zijn uiteengezet, namelijk dat men daarvan alleen het genot heeft, zoolang men als geapanageerde of běk ěl het gebruik heeft van den grond, waarop de leiding of het werk gelegen is, gelijk mede van den grond, welke daardoor wordt gë̈rrigeerd. Zoolang dat gebruiksrecht duurt, is echter het recht op de leiding, het werk en het water onaantastbaar. Bij gemeenschappelijken aanleg is dat recht ook gemeenschappelijk, en wordt geheel beheerscht door de onderlinge overeenkomsten tusschen de belanghebbenden ${ }^{2}$. Derden kunnen het water slechts bekomen, wanneer de rechthebbenden het hun willen afstaan, en onder zoodanige voorwaarden als in elk geval worden bedongen. Intusschen heeft ook de rechthebbende op den grond, voor het graven van leidingen en het maken van waterwerken, de vergunning van de overheid noodig; terwijl eindelijk niemand kan gedwongen worden leidingen of werken op zijn grond te dulden ten behoeve van een ander. Derde belanghebbenden kunnen zich tegen het maken van nieuwe leidingen of werken in rechten verzetten, mits hunne actie binnen het jaar na het plegen van het feit instellende ${ }^{3}$.

\footnotetext{
1 Vergl. Ibid. p. 314 en vv., 322 en vv.

${ }^{2}$ In geval van gemeenschappelijke belangen wordt veelal door de rechthebbenden één persoon aangewezen, om voor het gewone onderhoud en voor de gewone waterverdeeling te zorgen. Zoodanig persoon heet: pangoeloe banjoe(N) of p. $\operatorname{toj} \mathrm{j}(\mathrm{K})$.

3. Vergl. Anggĕr Sadåså, art. 43 ; Spaan, t. a. p., p. 68 en vv.
}

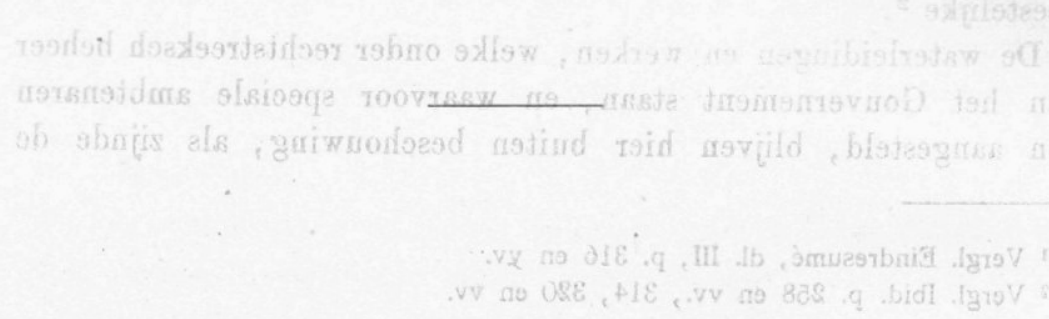

